EFFECTS OF CHANNEL MODIFICATIONS ON THE HYDROLOGY OF

CHICOD CREEK BASIN, NORTH CAROLINA, 1975-87

By Robert R. Mason, Jr., Clyde E. Simmons, and Sharon A. Watkins

U.S. GEOLOGICAL SURVEY

Water-Resources Investigations Report 90-4031

Prepared in cooperation with the

U.S. DEPARTMENT OF AGRICULTURE, SOIL CONSERVATION SERVICE

Raleigh, North Carolina

1990 
DEPARTMENT OF THE INTERIOR

MANUEL LUJAN, JR., Secretary

U.S. GEOLOGICAL SURVEY

Dallas L. Peck, Director

For additional information write to:

District Chief

U.S. Geological Survey Post Office Box 2857

Raleigh, North Carolina 27602
Copies of this report can be purchased from:

U.S. Geological Survey Books and Open-File Reports Section Federal Center, Building 810 Box 25425

Denver, Colorado 80225 


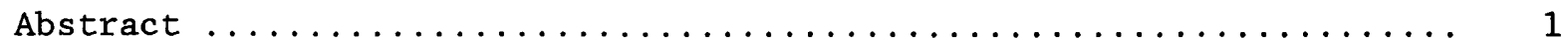

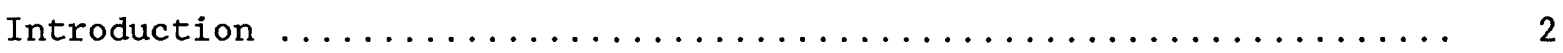

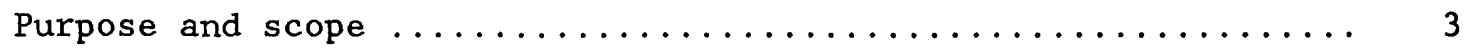

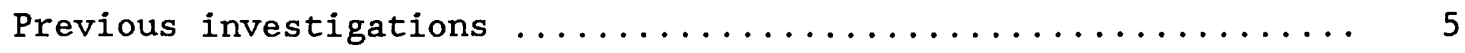

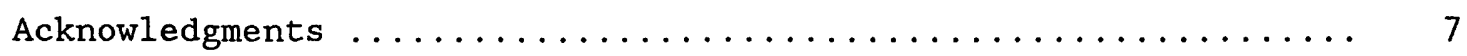

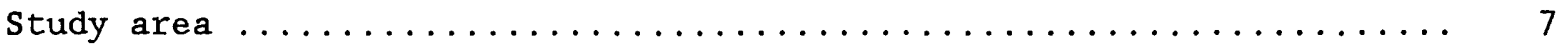

Basin description $\ldots \ldots \ldots \ldots \ldots \ldots \ldots \ldots \ldots \ldots \ldots \ldots \ldots \ldots \ldots$

Channel modifications in Chicod Creek basin ............. 10

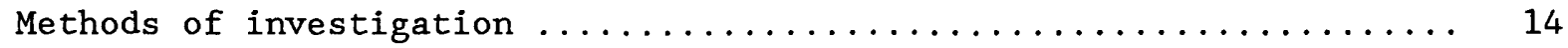

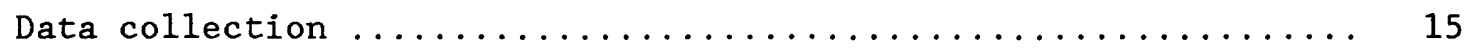

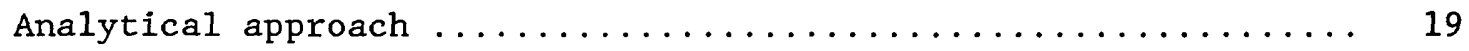

Hydrologic effects of channel modifications $\ldots \ldots \ldots \ldots \ldots \ldots \ldots \ldots . \ldots \ldots$

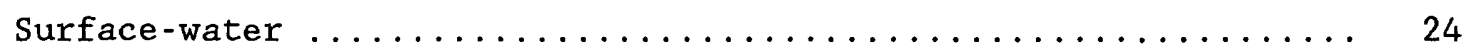

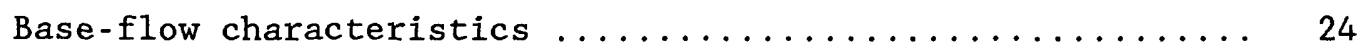

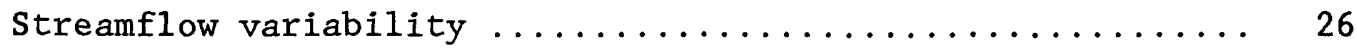

Hydraulic and flood characteristics ................ 27

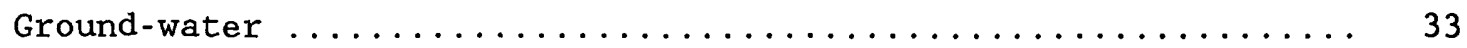

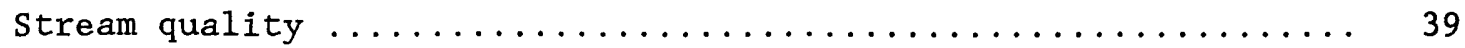

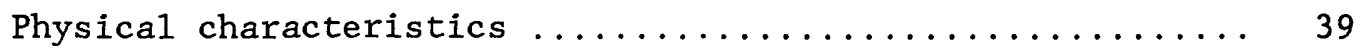

Suspended sediment .................... 39

Temperature ...................... 48

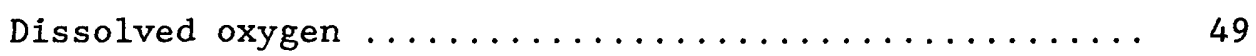

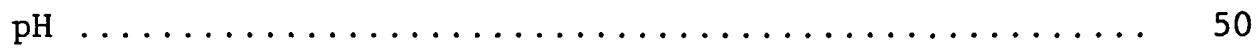

Chemical characteristics .................... 50

Major dissolved constituents ............... 51

Nutrients ......................... 58

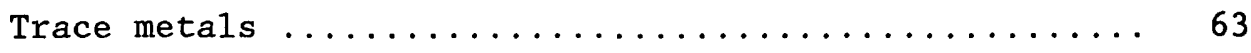

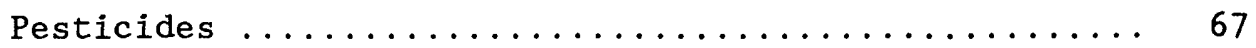

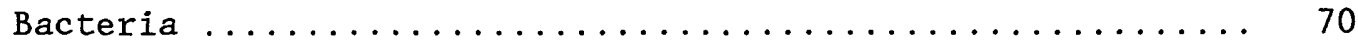

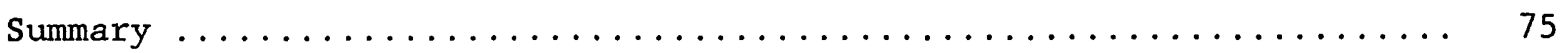

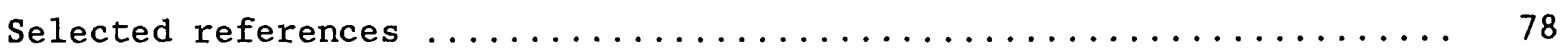

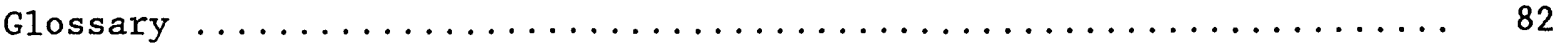




\section{ILLUSTRATIONS}

Page

Figure 1. Map showing study area and location of data-collection sites and channel modifications ................ 4

2. Map showing data-collection sites, dates of completed channel modifications, grade-control structures and sediment traps in the Chicod Creek basin ............

3. Photographs of typical modification operations in the Chicod Creek basin: A, clearing and snagging in the main stem of Chicod Creek; B, excavation by dragline in the upstream main stem of Chicod Creek .............

4. Photograph of sediment trap on Juniper Branch upstream

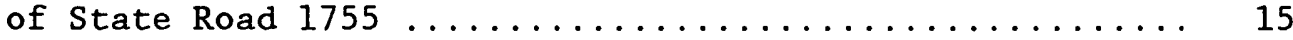

5. Flow chart showing statistical analysis and decision-making

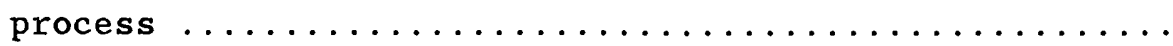

6. Flow-duration curves for Juniper Branch and Chicod Creek before, during, and after modifications and for Creeping Swamp during concurrent periods ............

7. Photograph of stream channel at Chicod Creek (site 4)

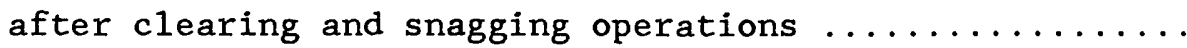

8. Cross section of Juniper Branch at well Pi-527 showing channe 1 bottom and flood-plain elevation before, during, and after excavation, and estimated

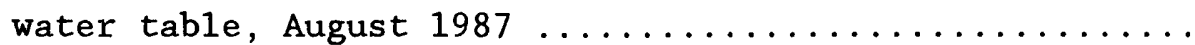

9. Measured mean streamflow velocity as a function of stream cross-sectional area at Chicod Creek (site 2) before

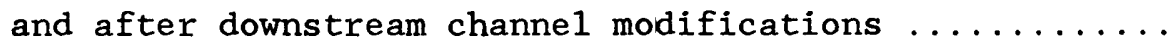

10. Diagram showing hypothetical widths of hydrographs at peak flow and at 75 percent of peak flow before and after channel modifications ............... 32

11. Drainage of surficial aquifer after channel modification .. 34

12. Cumulative rainfall-runoff relation for Juniper

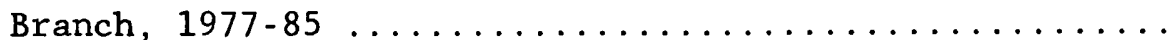

13-16. Sediment-transport relations for:

13. Juniper Branch (site 1) before, during, and after channel modifications 
14. Chicod Creek (site 2) before, during, and after

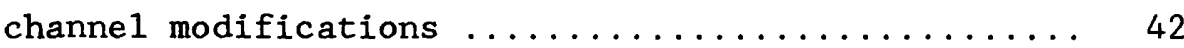

15. Cow Swamp (site 3) before, during, and after channel modifications ................... 43

16. Chicod Creek (site 4) before, during, and after channe1 modifications .................. 4

TABLES

Page

Table 1. Types of data and sampling frequency at surface-water data sites ............................. 16

2. Ground-water observation we11s, physical characteristics, and frequency of data collection ................ 18

3. Summary of initial covariance models .............. 21

4. Lane's variability index at Juniper Branch (site 1) and Chicod Creek (site 2) before, during, and after channel modifications and at unmodified Creeping Swamp (site 5) for concurrent periods .............. 26

5. Summary of streamflow hydrograph widths (in hours) at 75 percent of peak flows at Juniper Branch (site 1) and Chicod Creek (site 2) before, during, and after modifications and at unmodified Creeping

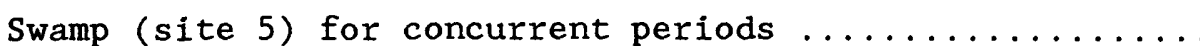

6. Summary of lag (in hours) between occurrence of peak flows at Juniper Branch (site 1) and Chicod Creek (site 2) and occurrence of peak flow at unmodified

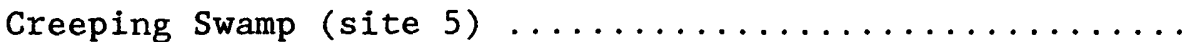

7. Summary statistics for ground-water levels in Chicod Creek basin observation wells during base-flow periods before, during, and after channel modifications, and in the unmodified Creeping Swamp basin observation we11 for concurrent periods . . . . . . . . . . . . . . . 
8. Mean ground-water levels in Chicod Creek basin observation wells during base-flow periods before, during, and after channel modifications after adjustment

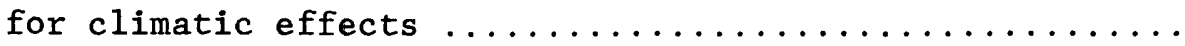

9. Suspended-sediment and streamflow data for Juniper Branch (site 1) and Chicod Creek (site 2) before, during,

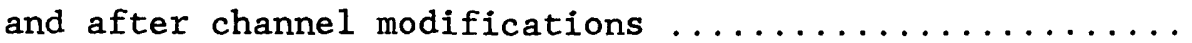

10. Summary statistics for selected physical characteristics and streamflow for selected base-flow and high-flow periods before, during, and after channel

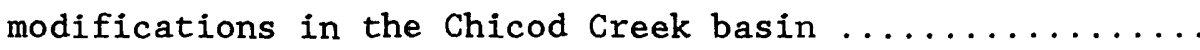

11. Summary of concentrations and flow-adjusted mean concentrations of selected physical characteristics and streamflow sampled before, during, and after channel modifications

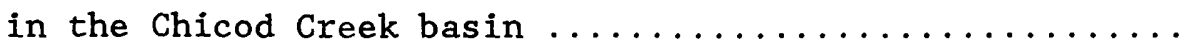

12. Summary statistics for concentrations of major dissolved constituents during selected base-flow and high-flow periods before, during, and after channel modifications in the Chicod Creek basin (sites 1,2, 3, and 4) and for concurrent periods in the unmodified

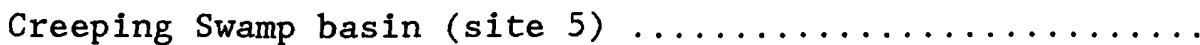

13. Summary of concentrations and flow-adjusted mean concentrations of major dissolved constituents collected before, during, and after channel modifications in the Chicod Creek basin (sites 1 , 2,3 , and 4) and for concurrent periods in the

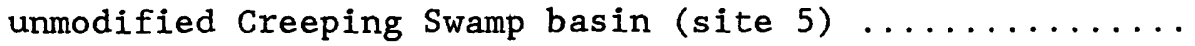

14. Summary statistics for concentrations of nutrients during selected base-flow and high-flow periods before, during, and after channel modifications in the Chicod Creek basin (sites 1, 2, 3, and 4) and for concurrent periods in the unmodified Creeping Swamp

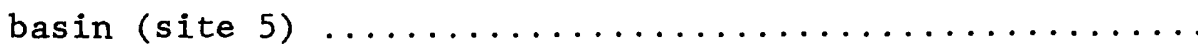


15. Summary of concentrations and flow-adjusted mean concentrations of nutrients collected before, during, and after channel modifications in the Chicod Creek basin (sites 1,2, 3, and 4) and for concurrent periods in the unmodified Creeping Swamp

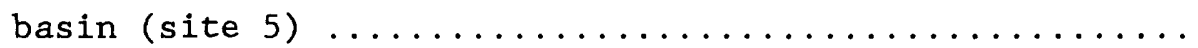

16. Summary statistics for concentrations of trace metals during selected base-flow and high-flow periods before, during, and after channel modifications in the Chicod Creek basin (sites 1, 2, 3, and 4) and for concurrent periods in the unmodified

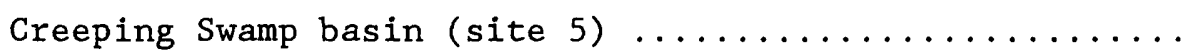

17. Summary of concentrations and flow-adjusted mean concentrations of trace metals collected before, during, and after channel modifications in the Chicod Creek basin (sites $1,2,3$, and 4) and for concurrent periods in the unmodified Creeping Swamp basin (site 5) ........

18. Concentrations of selected organic compounds in bottommaterial samples collected at Chicod Creek basin sites ...

19. Concentrations of selected total pesticides, discharge, and suspended-sediment concentrations of instream

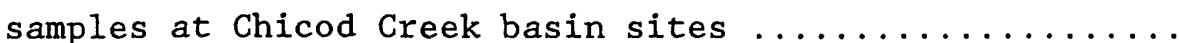

20. Bacteriological counts in water samples from the Chicod Creek basin before, during, and after

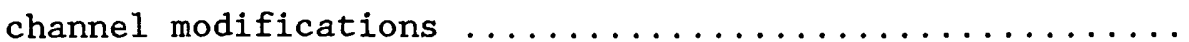


EFFECTS OF CHANNEL MODIFICATIONS ON THE HYDROLOGY OF CHICOD CREEK BASIN, NORTH CAROLINA, 1975-87

By Robert R. Mason, Jr., C1yde E. Simmons, and Sharon A. Watkins

\section{ABSTRACT}

From 1978 to 1981, selected stream channels throughout the 60-squaremile Chicod Creek basin underwent modifications to increase drainage efficiency and reduce flooding potential. Drainage modifications in this Coastal Plain basin consisted primarily of channel excavation and clearing of channel blockages. In 1975, prior to the modifications, a study was begun to define hydrologic conditions of the basin before, during, and after modifications, and to determine what changes could be attributed to the channe1 modifications.

Streamflow was altered at several sites in the basin during and after channel improvements. At Juniper Branch (site 1) minimum flow was increased from less than 0.1 cubic foot per second to 0.4 cubic foot per second, and streamflow variability was reduced from an index value of 0.87 to 0.49 . At site 2 on Chicod Creek, in-channel velocity was increased from 0.4 foot per second to 1.5 feet per second for the same depth and cross-sectional areas.

Excavation increased the carrying capacity of streams in the Chicod Creek basin and reduced the occurrence of overbank flows. Prior to excavation the channel capacity of Juniper Branch near observation well Pi527 ranged from 2 to 10 cubic feet per second. A daily mean flow of more than 10 cubic feet per second occurred on more than 155 days before modification. During modification, the channel capacity was increased to 88 cubic feet per second, which was probably exceeded on only 5 days during this period. After modification, channel capacity declined to 44 cubic feet per second because of partial filling of the channel by sediment. A daily mean flow of 44 cubic feet per second at this site was exceeded on only 36 days after modification. Thus, parts of Juniper Branch flood plain that were commonly inundated before modification were infrequently inundated after modification.

Ground-water level declines of 0.4 and 0.2 feet were observed in wells 180 and 250 feet, respectively, from Juniper Branch during the channel modification phase. These declines probably were due to the channel 
excavations but may include some water-level changes related to climate effects. The lowering of ground-water levels near the excavated channels resulted in more water moving through the ground-water system and appearing as increased base flow in the stream. However, the total water budget of the basin remained unchanged because the resultant increase in ground-water recharge was balanced by a corresponding decrease in overland runoff. Most surface-water and ground-water hydrologic conditions tended to return to premodification levels after the modifications.

Water-quality characteristics monitored during the investigation included physical, chemical, and bacteriological characteristics. The physical characteristics monitored were suspended sediment, temperature, dissolved oxygen, and $\mathrm{pH}$. Of these, only sediment concentrations showed significant increases, and these occurred only during the active modification periods. At Juniper Branch, sediment discharge increased from 20 tons per day to 50 tons per day during modifications at a flow rate of 100 cubic feet per second but returned almost to premodification level after modifications.

Chemical characteristics studied included major dissolved constituents, nutrients, trace metals, and pesticides. Statistically significant changes in a number of chemical constituents were observed during and after channel modifications and were attributed to channel excavations. These changes ranged from a decline in total iron concentrations of 77 percent at site 1 to an increase in total nitrite concentrations of 130 percent at site 2 .

Dieldrin and DDT were the most frequently detected pesticides in stream-bottom sediments and in stream water. Bacterial contamination, primarily from livestock and poultry sources, was detected at all the sampling sites, but no significant changes in bacterial counts were observed during or after channel modifications.

\section{INTRODUCTION}

The hydrologic effect of channelization is a subject of intense debate. Many observers contend that channelization lowers ground-water levels, reduces recharge to shallow aquifers, reduces minimum streamflows, increases peak streamflows, and affects water quality by increasing erosion, sedimentation, and water temperature, and by concentrating nutrients and agricultural pollutants in downstream waters. Others believe that the effects on ground-water levels, flow regimes, and sediment concentrations 
are temporary, limited, and local in extent, and that there are too little data with which to assess the effects of channelization on water-quality. In response to such debate and the public's concern over the environmental effects of federally financed channelization projects, a subcommittee of the House of Representatives' Committee on Government Operations held hearings on channelization practices in 1971 and 1973. In its final 1973 report, the committee states:

\begin{abstract}
A common thread running through the Subcommittee's hearings, correspondence, and subsequent studies was not that channelization, per se, was evil, but rather that inadequate consideration was being given to the adverse environmental effects of channelization. Indeed, there is considerable evidence that little was known about these effects and, even more disturbing, little was done to ascertain them (U.S. House of Representatives, Committee on Government Operations, 1973).
\end{abstract}

In 1975, the U.S. Geological Survey, in cooperation with the U.S. Department of Agriculture, Soil Conservation Service, agreed to undertake a hydrologic study of the Chicod Creek basin in eastern North Carolina (fig. 1 ) to quantify the effects of small stream channel modifications. The study was designed to determine the magnitude of changes in flow regime, surfacewater quality, and ground-water levels caused by channel modifications. Data-collection networks were installed in October 1975. Channel modifications in the Chicod Creek basin were begun in November 1978 and were completed in December 1981. The data collection for this investigation was completed in March 1987.

This study is the most comprehensive investigation conducted in North Carolina to define hydrologic changes caused by channel modifications. It is one of the first to be conducted on a stream-modification project designed and constructed in compliance with new channel guidelines developed jointly by the U.S. Department of Agriculture, Soil Conservation Service (SCS), and the U.S. Fish and Wildlife Service (1978) to mitigate the environmental effects of channel projects (guidelines are summarized in a subsequent section of this report).

\title{
Purpose and Scope
}

This report presents analyses and comparisons of hydrologic conditions in the Chicod Creek basin before, during, and after channel modifications 


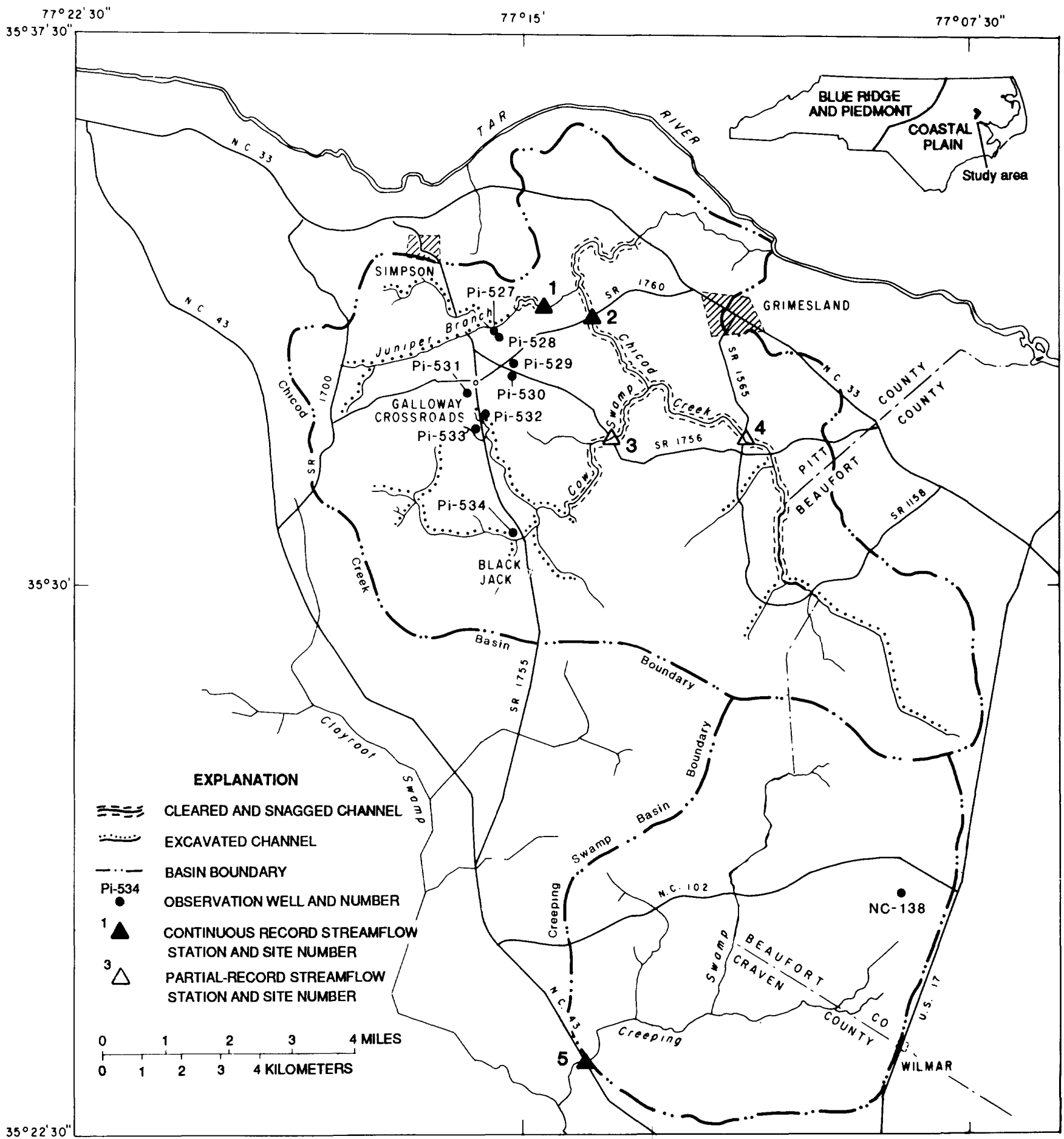

Figure 1.--Study area and location of data-collection sites and channel modifications. 
for the period October 1975 to March 1987 to quantify the effects of modifications on the hydrologic regime. Comparisons included modification effects on base flows; floods and hydrograph characteristics; ground-water recharge and discharge; water-table fluctuations; and selected physical, chemical, and bacteriological water-quality characteristics. Hydrologic data networks included five flow sites, nine ground-water sites, and five water-quality sites.

Data collection was designed to define hydrologic characteristics during three specific phases of the project: a 3-year period before channel modifications (October 1975-June 1979); a 3-year period during channel modifications (July 1979-December 1981); and, a 5-year period immediately following completion of channel modifications (January 1982-March 1987). Hydrologic data were collected in the adjacent Creeping Swamp basin for control (background) purposes. Comparative procedures include analysis of covariance, analysis of variance, and other classical statistical procedures.

\section{Previous Investigations}

The geomorphological effects of channel modifications have been studied by numerous researchers. Schumm and others (1984), Brookes (1985), and Harvey and others (1985) provide comprehensive reviews of river channelization and geomorphological considerations. Brookes (1985) studied geomorphological effects according to four types of channel-modification activities: (1) widening, deepening, or straightening the channel; (2) clearing and snagging, the process of removing brush, logs, and other flow obstructions from the channel and its banks; (3) diking, and (4) bank stabilization. He found that channel-modification types 1 and 2 usually result in increased channel capacity and can cause significant increases in shear stresses on the channel sediments.

The biological and ecological effects of stream modifications have also been studied, often producing differing conclusions. For example, Duvel and others (1976) investigated six coldwater streams to determine the effect of channel modifications instituted prior to and following Hurricane Agnes. No long-term deleterious effects on water quality, attached algae, benthic fauna or forage populations were detected. However, trout were greater in numbers and weight in natural streams than in channelized streams. On the other hand, Rosendahl and Waite (1978) compared the phosphorus transport 
characteristics of channelized and meandering streams and found that the meandering systems had greater algal and macrophyte phosphate uptake rates and lower plankton and sediment release rates. Similarly, Hahn (1982) reported that stream channelization results in loss of streambank vegetation, increased water temperature and turbidity, change in water velocity, change in size and stability of substrates, and loss of habitat.

The water-quality effects of channelization on various streams in North Carolina also have been investigated. For example, O'Rear (1975) conducted a comparative study of channelized and unchannelized stream segments of Swift Creek in Pitt County. He found that temperatures and dissolved oxygen content were higher in the channelized segment than in the unchannelized segment. He also found no difference in concentrations of nutrients or dissolved metals between the segments in the water and reported that bottom sediments in the unchannelized segment contained greater concentrations of some metals than in the bottom sediments of the channelized stream segment. 0 'Rear suggested that the higher percentage of organic material in the sediments of the unchannelized stream segment accounted for the higher metal concentration.

Similar conclusions have been drawn in other studies. In a broad, comparative study of three unchannelized streams and four channelized streams located in the North Carolina Coastal Plain, Kuenzler and others (1977) determined that channelized streams attained higher velocities, carried greater particulate loads, and were more turbid than unchannelized streams. On the average, the channelized streams had lower color and lower iron concentrations but higher specific conductance, turbidity, $\mathrm{pH}$, and phosphorus concentrations and were very rich in nitrate. They reported that a marked seasonal deficiency existed in dissolved oxygen in unchannelized streams but that dissolved oxygen was abundant throughout the year in channelized streams.

The effects of channel modifications on flow regime also have been studied. Heath (1975) and Winner and Simmons (1977) reported a change in flow regime following the channelization of Ahoskie Creek in Hertford County. After channelization, base flow and peak discharges increased and flows in the mid-range decreased; however, the relation between cumulative rainfall and cumulative runoff did not change.

Simmons and Watkins (1982) reported that channel excavation of Black River near Dunn, North Carolina, caused significant changes in several hydrologic conditions. After the Black River channel was deepened more than 
$2 \mathrm{ft}$ (feet), water levels in observation wells within $100 \mathrm{ft}$ of the stream declined an amount inversely proportional to the distance from the stream; however, water levels in a well $500 \mathrm{ft}$ from the stream did not change. Flow velocities were 100 percent higher and instream water temperatures were about one Celsius degree higher after construction than before and during construction. After channelization, concentrations of dissolved oxygen also increased, with the percent of saturation increasing 20 to 25 percent during periods of low streamflow. Maximum concentrations of suspended sediment increased from about $75 \mathrm{mg} / \mathrm{L}$ (milligrams per liter) prior to construction to over $2,000 \mathrm{mg} / \mathrm{L}$ during construction.

In addition to this report, the progress and preliminary findings of this investigation were presented in two interim reports. The first report (Simmons and Aldridge, 1980) characterized streamflow, stream quality, and ground-water conditions prior to channel modifications in the Chicod Creek basin. The second, (Watkins and Simmons, 1984) compared preliminary hydrologic conditions in the basin before and during modifications and included ground-water, surface-water, and water-quality data up to late 1981.

\section{Acknowledgments}

Special acknowledgment is given to local landowners Mr. J.C. Galloway (deceased, 1986), Greenville, N.C., and Mr. Larry Tucker, Grimesland, N.C., for their devoted efforts in collecting daily suspended-sediment samples on Chicod Creek during the study period and for their assistance in locating and constructing observation wells and stream gages. Special high-flow, suspended-sediment samples and weather data were provided by $\mathrm{Mr}$. Tucker for the Juniper Branch station during 1979-80. Soil Conservation Service personnel in Greenville, N.C., under supervision of Mr. Albert Coffey, provided level data and local weather information that were an integral part of the investigation.

\section{STUDY AREA}

The study area includes the Chicod Creek and Creeping Swamp basins (fig. 1). The physiographic and hydrologic characteristics of the Chicod Creek basin and the adjacent unmodified control basin, Creeping Swamp, are described, including hydrogeologic characteristics and some land-use and 
agricultural features. The history of channel improvements in the Chicod Creek basin also is discussed, and descriptions are given of the procedures and structures used in the channel-modification process.

\section{Basin Description}

The Chicod Creek basin, an area of approximately $60 \mathrm{mi}^{2}$ (square miles), is in the Coastal Plain physiographic province of eastern North Carolina. Approximately 90 percent of the basin is in Pitt County, and 10 percent is in Beaufort County (fig. 1). Chicod Creek originates in the western part of Beaufort County and flows north to the Tar River. Major tributaries are Cow Swamp and Juniper Branch, whose drainage areas are $18 \mathrm{mi}^{2}$ and $14 \mathrm{mi}^{2}$, respectively.

The basin is characterized by sluggish, low-gradient streams and relatively flat topography. The average gradient of Chicod Creek is only about $0.3 \mathrm{ft} / \mathrm{mi}$ (foot per mile); land-surface elevations in the basin range from about 10 to $60 \mathrm{ft}$ above sea level. Relatively broad swamplands are abundant. Prior to channel modifications, stream channels were poorly defined, or braided, and runoff from moderate and, in some cases, even small storms quickly filled the shallow channels, causing extensive flooding of adjacent lowlands. Short reaches of major stream channels, usually less than a mile in length, had been excavated at various times since the early 1900's; but until 1ate 1978, an organized, large-scale effort to improve flow and drainage conditions in the entire basin had not been made.

Ground water in the Chicod Creek basin occurs in water-bearing sands, clays, and calcareous sediments that extend to depths of 900 to $1,200 \mathrm{ft}$ below land surface. The uppermost sediments include deposits of Holoceneand Pleistocene-age that are underlain by the Pliocene Yorktown Formation and Middle Eocene Castle Hayne Limestone. The surficial deposits are composed primarily of sand and silt beds ranging from 10 to $20 \mathrm{ft}$ thick. These sediments are the major source of water for shallow wells and for base flow to streams.

The upper part of the Yorktown Formation is composed of layers of gray silty clay, whereas the lower part is composed of dark blue-gray sandy clay containing shells and other remains of marine organisms. The average thickness of the Yorktown Formation is about $40 \mathrm{ft}$. Within the study area, the Yorktown Formation and the surficial deposits constitute the surficial aquifer. The surficial aquifer is of primary interest in this study because 
all of the ground-water recharge enters this aquifer and nearly all of the ground water moves through it and discharges into Chicod Creek or its tributaries.

Land use in the Chicod Creek basin is dominated by agriculture and forests. During the study, overall land use in the basin remained relatively unchanged. About 45 percent of the basin is crops and pastures; approximately 50 percent is dense hardwood and pine forest; and the remaining 5 percent is residential areas, roadways, and water courses.

Field reconnaissances of the basin were conducted during 1978 and 1986 to determine the prevalence and types of livestock and agricultural land-use activities in the basin. Although only a small number of cattle and horses were observed (less than 100), the basin contained many poultry and swine farms. Several poultry farms, each having 80,000 or more chickens, are in proximity to streams. With the exception of direct outlets to streams from holding ponds adjacent to poultry and livestock shelters, point sources of pollution were not observed in the basin.

Tobacco, soybeans, and corn are the primary row crops, and numerous ponds, 1 to 4 acres in size, are located throughout the basin for irrigation. Almost all agricultural fields are separated from streams by a dense growth of trees, which are predominantly pine, sweet gum, poplar, and cypress, and heavy undergrowth.

Although no major changes in predominant land use occurred between 1978 and 1986, a few minor changes were observed. Increases of 2 to 3 percent in housing and croplands are estimated to have taken place. Much of the new housing was concentrated in the Juniper Branch basin where 30 to 50 new houses were constructed in mostly wooded areas along the headwaters of that stream. Several large farm ponds, ranging in size from about 2 to 10 acres, were also constructed during the later portion of the study period. The Chicod Creek basin, as a whole, was a rural basin dominated by agricultural activities throughout the study period.

The Creeping Swamp basin is south of and adjacent to the Chicod Creek basin (fig. 1). At the gage on Creeping Swamp (site 5) the basin is approximately $27 \mathrm{mi}^{2}$, of which 38 percent is in Pitt County, 37 percent is in Beaufort County, and 25 percent is in Craven County. Approximately 70 percent of the basin is forested or cut-over scrubland; about 25 percent is row crops and other agricultural lands; and the remaining 5 percent of the basin is developed lands such as residential property and highways. Channel gradients, flood plains, and other physical characteristics of streams in 
the Creeping Swamp basin are similar to those in the Chicod Creek basin. During the study period, land-use changes and modifications of channel and drainage systems in the Creeping Swamp basin were minor.

Ground water in the Creeping Swamp basin occurs in sediments similar to the Chicod Creek basin, consisting of sand, clay, and calcareous deposits. The surficial sand and silt beds are up to $15 \mathrm{ft}$ thick and furnish water for wells and base flow to streams.

\section{Channel Modifications in Chicod Creek Basin}

The history of modern channel modifications in the Chicod Creek basin began in 1966 when the SCS obtained approval to excavate stream channels. The project was delayed on several occasions because of delays in funding and by litigation initiated by groups concerned about possible adverse environmental impacts. In March 1972, the U.S. District Court granted the Natural Resources Defense Council an injunction preventing initiation of the project without an environmental impact statement. In September 1977, a compromise agreement was reached in Federal Court, and the long-planned channel modifications were begun in November 1978. Modifications continued during the next 3 years but were interrupted periodically by inclement weather and were suspended February 1 to June 30 each year to avoid interference with herring spawning runs. When channel modifications ended in December 1981, contractors had cleared and snagged $13 \mathrm{mi}$ of channel, excavated another $58 \mathrm{mi}$, and constructed 13 instream grade-control structures and 17 sediment basins (fig. 2). Upstream of N.C. Highway 33, virtually every natural and older artificial channel in the basin had been modified.

The channel modifications were conducted in accordance with special construction guidelines developed jointly by the U.S. Department of Agriculture, SCS, and the U.S. Fish and Wildlife Service (1978). The guidelines, effective March 1978, incorporated several new construction practices designed to mitigate the negative environmental effects of channel projects. These practices include construction of channels that follow the natural meandering of the stream, excavation from one side of the stream only, spreading rather than piling spoil material, and the use of clearing and snagging techniques along environmentally sensitive reaches rather than channel excavation. The SCS also constructed instream sediment traps to decrease sediment transport, installed grade control structures at various 


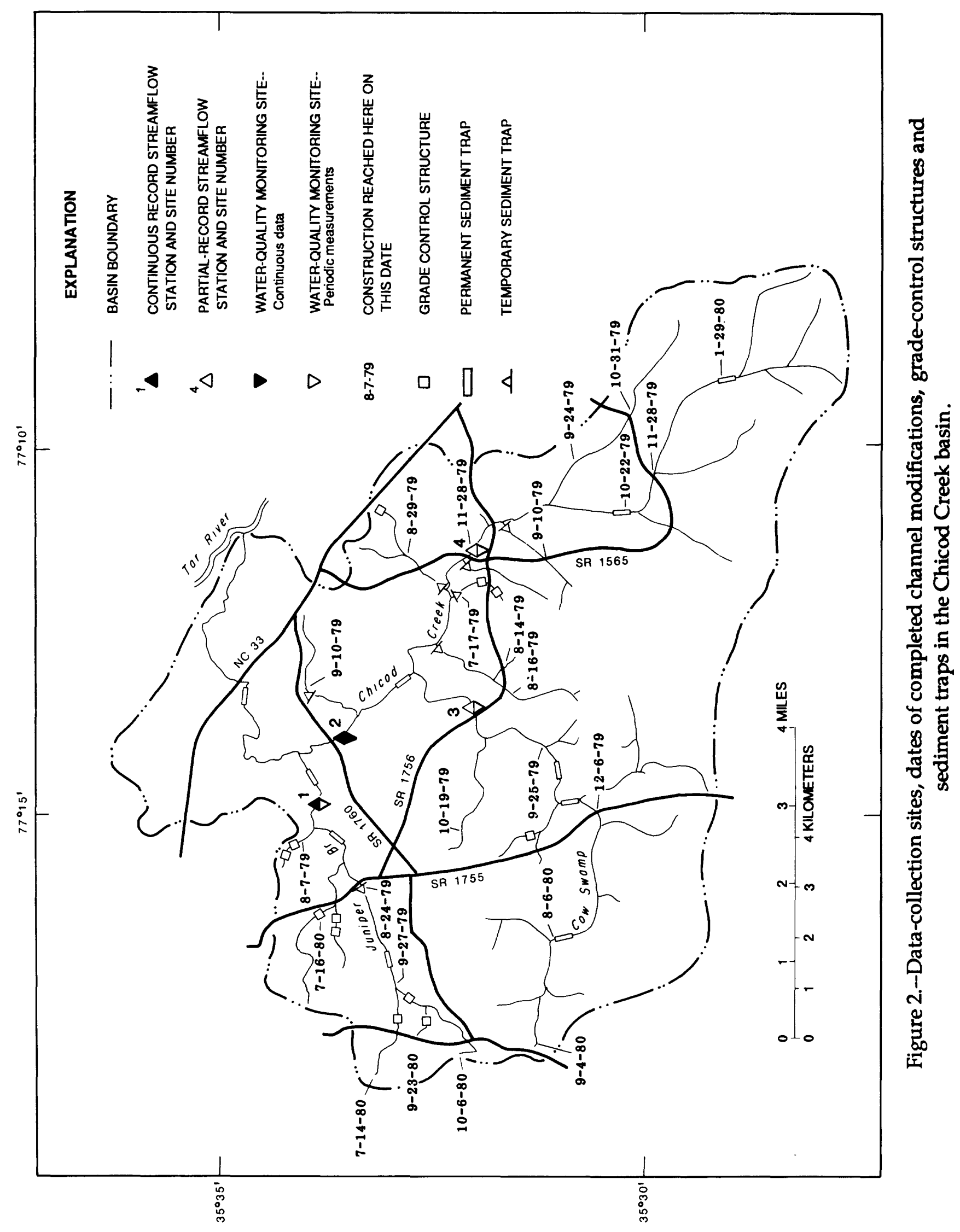


points throughout the basin to minimize channel degradation, and planted grass on spoil areas, unstable stream banks, and barren construction areas.

The modification program consisted of two phases. The first phase began in November 1978 and continued through January 1979. During this period, the first $3 \mathrm{mi}$ of channel, Juniper Branch at Secondary Road 1766 downstream to Chicod Creek at N.C. Highway 33, were cleared and snagged (fig. 2). This activity was downstream of and had no effect on the part of Chicod Creek basin studied in this investigation.

The second phase of channel modifications that affected the study reaches began July 1979 and ended December 1981. As shown in figure 1, channels were generally excavated on the smaller headwater streams, but were cleared and snagged along the larger main streams. Little change was made along reaches having naturally deep pools where the streambed was at or below design elevation. Consequently, some areas underwent more alteration than others. For example, all tributaries and main-stream channels of Juniper Branch, upstream of site 1 , were excavated; whereas, the main channel of Chicod Creek for several miles upstream of site 2 was relatively unaltered.

During the second phase, clearing and snagging operations were confined mainly to stream reaches bordered by wooded swamp. Heavy equipment was used to move large obstacles such as logs, stumps, brush, and debris within the channel; but much of the clearing was done manually. Removed material was piled and bound with wire cables to prevent it from being washed back into the channel during storms.

Channel segments were modified simultaneously in as many as four or five subbasins. One streambank was generally cleared to provide access for the surveyors and heavy equipment such as backhoes and draglines. Locations of grade-control structures, sediment basins, and channels to be excavated were surveyed. Excavation generally began at the downstream end of a prepared reach and progressed upstream (fig. 3). Channels generally were excavated to depths of 2 to $3 \mathrm{ft}$ below the existing stream bed, but at sediment traps the excavation was as much as $7 \mathrm{ft}$. Culverts were installed under private roads. Where channel excavation conflicted with construction at grade-control structures and sediment basins, excavation operations were suspended temporarily or moved to another area until completion of the structure or basin. Spoil areas and streambanks were shaped and seeded with grass following excavation to prevent excessive erosion. 
A.

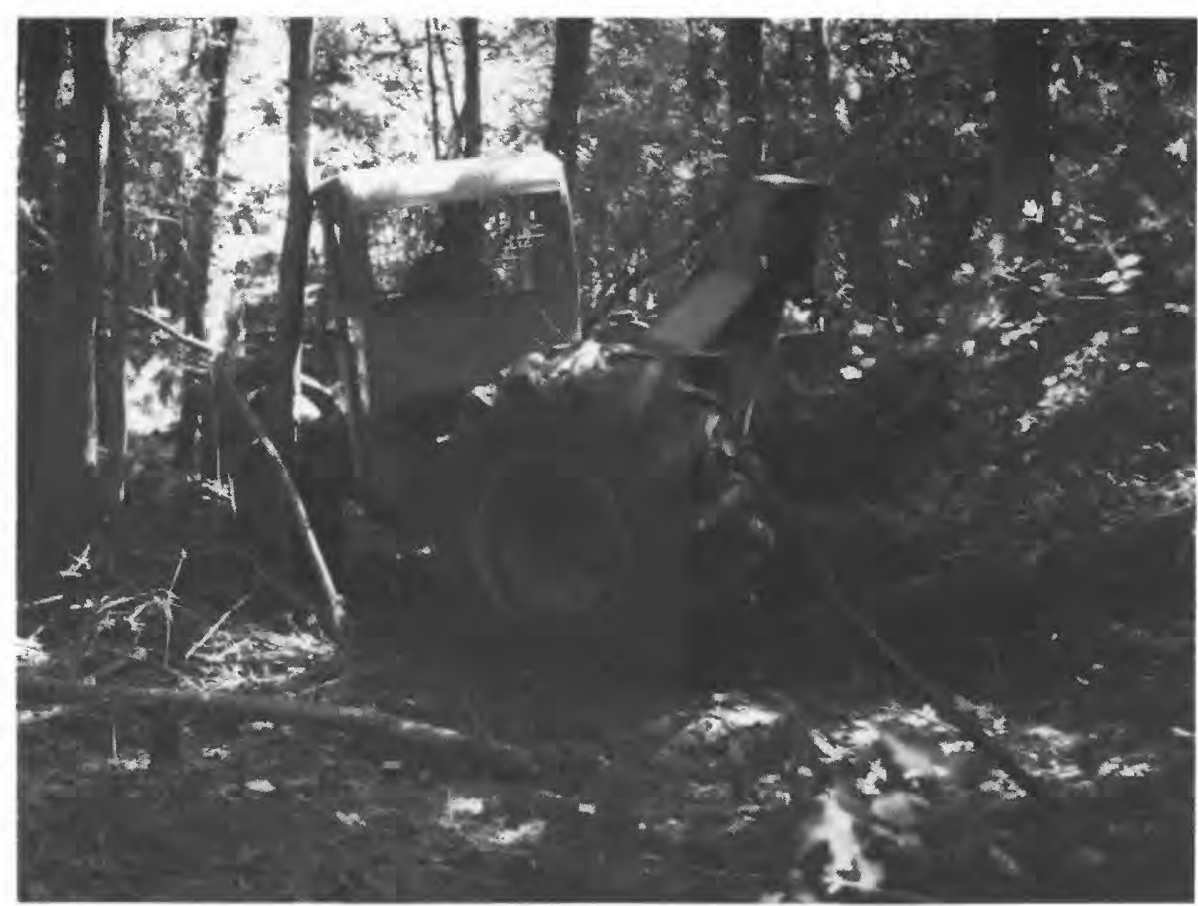

B.

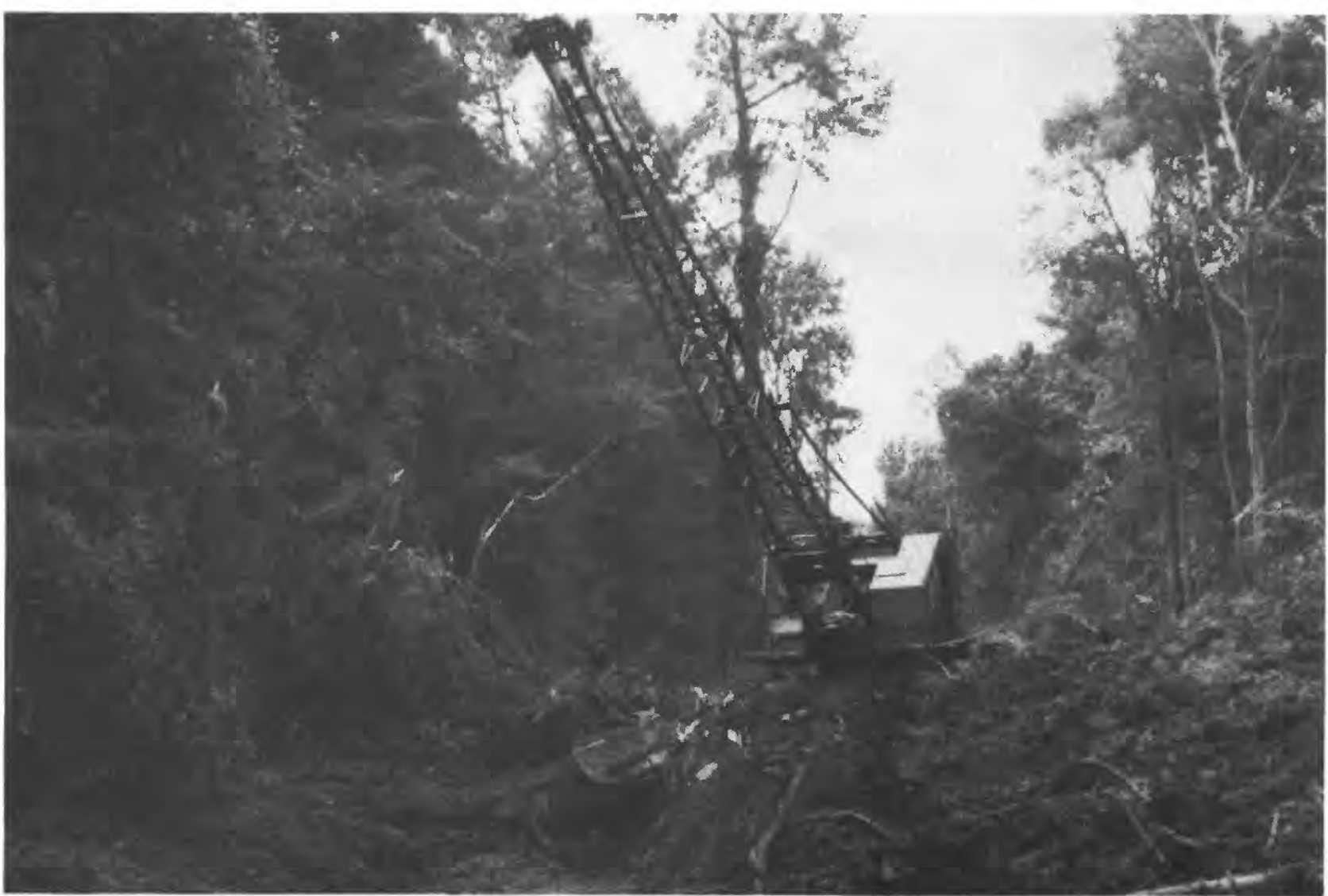

Figure 3.--Typical modification operations in the Chicod Creek basin: A, clearing and snagging in the main stem of Chicod Creek; B, excavation by dragline in the

upstream main stem of Chicod Creek.

(Photographs by Albert Coffey, U.S. Department of Agriculture, Soil Conservation Service) 
Grade-control structures were installed on relatively high-gradient reaches to improve channel stability and reduce erosion (fig. 2). These structures consist of small earthen dams through which large-diameter corrugated metal pipes were placed. The pipe invert at the downstream outlet was placed flush with the downstream channel bed, but the upstream pipe invert was placed substantially lower ( $1-2 \mathrm{ft})$. than the upstream channel bed. Approach and outlet sections were wider than adjacent channels and were lined with sand bags and concrete fill to prevent erosion. Flow is confined within the pipe through the transition from the upstream bed elevation to the downstream bed elevation; this prevents scour and degradation of the channel.

Sediment basins, or traps, were constructed to decrease sediment runoff during and after construction. Ten traps were permanent, and seven were for temporary use during construction (fig. 2). The permanent traps were generally longer than the temporary ones and were maintained after channel modifications. Traps were constructed in the existing or design channel; lengths varied from 210 to $250 \mathrm{ft}$, widths were approximately twice as wide as the upstream channel, and depths were about $4 \mathrm{ft}$ deeper than adjacent reaches (fig. 4). The extra width and depth of the trap caused a reduction in flow velocities, allowing suspended sediment to be dropped from suspension and deposited in the trap, resulting in a net reduction in sediment transport (Schiebe, 1984). A substantial amount of sediment transported as bedload, which is composed of larger material that skips and rolls along the streambed, is also deposited in the traps. Because the bed of the trap is lower than adjacent channels, deposited sediment does not impede flow. Temporary traps were allowed to fill to the level of adjacent channel sections. Permanent traps were re-excavated periodically and after major storms.

During 1983, a few land owners excavated additional channel reaches upstream of the SCS modifications. These drainage improvements were modest compared to those of the SCS and involved only small areas along the headwaters of Cow Swamp immediately south of SR 1755 (fig. 1). The North Carolina Department of Transportation also replaced a bridge spanning Cow Swamp at SR 1755 during this period.

\section{METHODS OF INVESTIGATION}

During this study, hydrologic data were collected to define the surface-water, ground-water, and water-quality characteristics of streams in 
the Chicod Creek basin and to document trends or changes in these hydrologic regimes that might have resulted from channel modifications. Several analytical methods were used to compare and contrast data before, during, and after channel modifications and to identify parametric values and trends. Hydrologic data collected in the Creeping Swamp basin were used for comparative purposes.

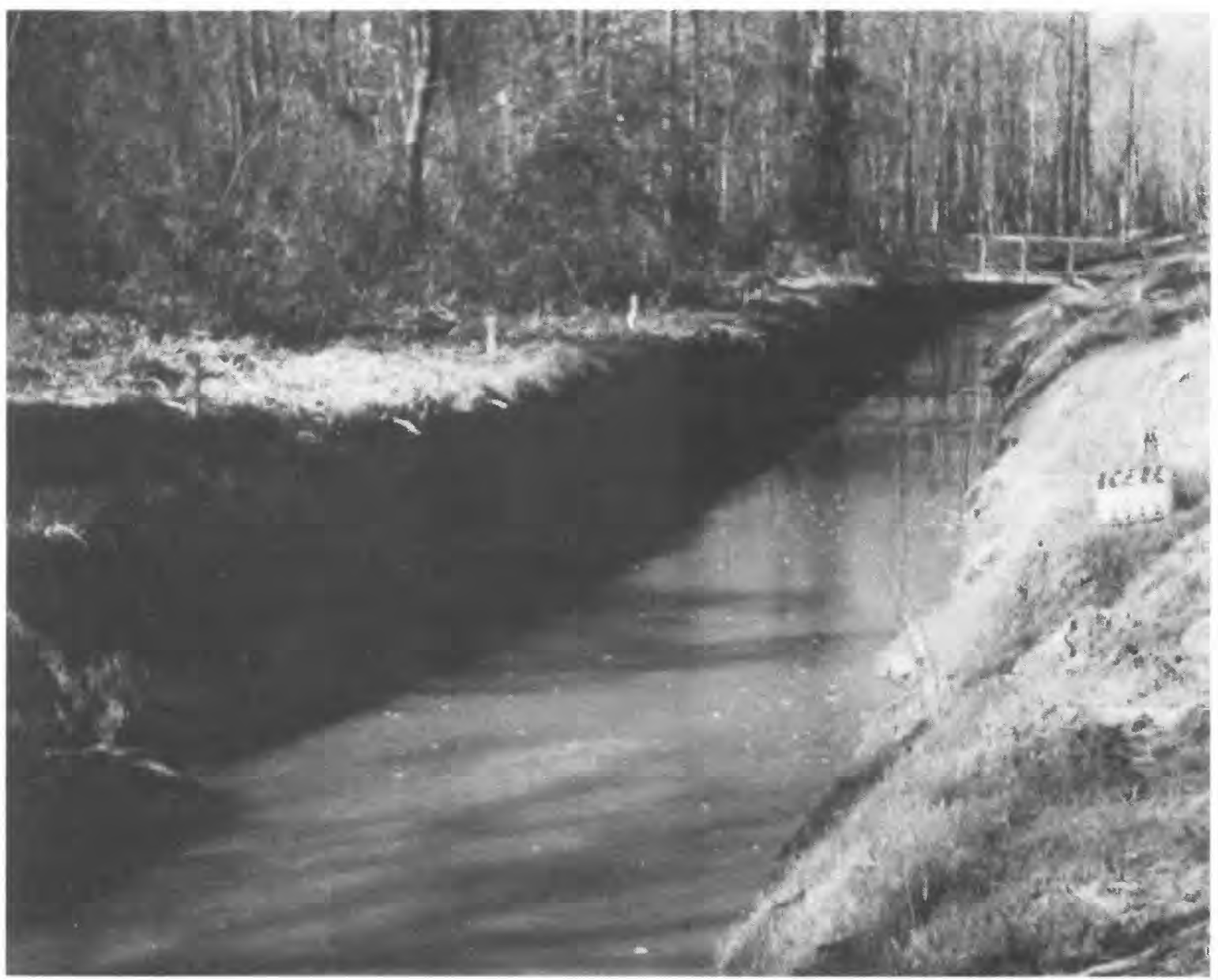

Figure 4.--Sediment trap on Juniper Branch upstream of State Road 1755. (Photograph by Stephen S. Howe, U.S. Geological Survey)

\section{Data Collection}

Continuous-stage records were collected at Juniper Branch (site 1) Chicod Creek (site 2) and at Creeping Swamp (site 5) for determining streamflow. Discharge measurements were made periodically at sites 3 and 4 , Cow Swamp and Chicod Creek, respectively, for defining the stage-discharge relation throughout a full range of flow conditions to support water-quality sampling (fig. 1 and table 1 ). 


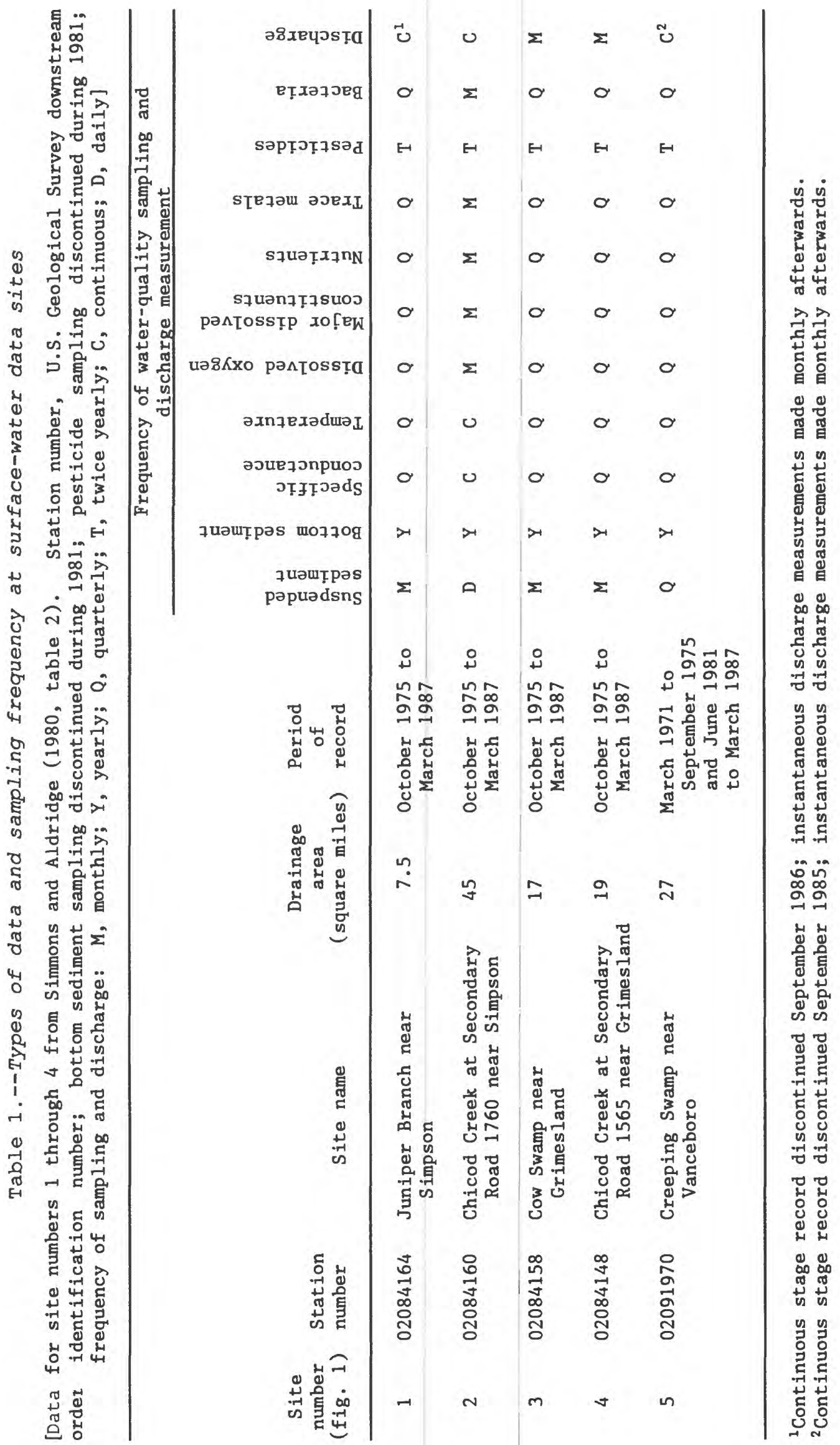


During the study, a number of modifications were made to the surfacewater data-collection network. The continuous-stage record at Creeping Swamp (site 5) was discontinued in September 1985 due to problems associated with beaver dams and concern over localized flooding caused by the dams. In September 1986, the continuous-stage record at Juniper Branch (site 1) was discontinued during reconstruction of a highway bridge. Periodic discharge measurements continued at both sites though March 1987 and were made at the times that water samples were collected.

Ground-water levels were measured at nine observation wells, eight in the Chicod Creek basin and one in the Creeping Swamp basin. The eight observation wells in the Chicod Creek basin were located at distances ranging from $150 \mathrm{ft}$ to $31 / 4 \mathrm{mi}$ from Juniper Branch (fig. 1). The depths of the wells range from 9 to $21 \mathrm{ft}$. Land-surface elevations at the observation wells range from about 27 to $60 \mathrm{ft}$ above sea level. Identification numbers assigned to the Chicod Creek basin wells consist of a sequence number preceded by $\mathrm{Pi}-$, which refers to Pitt County, where the wells are located; NC- is the identification prefix of the Creeping Swamp basin well.

Continuous water-level records were collected at wells $\mathrm{Pi}-527, \mathrm{Pi}-528$, $\mathrm{Pi}-529, \mathrm{Pi}-532, \mathrm{Pi}-533$, and Pi-534. Water levels at wells Pi-530 and Pi-531 were measured monthly. Well NC-138 was the control well and was operated as part of a statewide ground-water level monitoring network; it was $12 \mathrm{ft}$ deep and provided a continuous record of levels. Additional information regarding the observation wells is presented in table 2 .

Water-quality samples were collected periodically at each of the five streamflow sites to define water-quality characteristics throughout the range of streamflow. In addition, continuous specific-conductance and water-temperature data, and daily sediment data were collected at site 2 . During high-flow periods, sediment data were obtained by means of a stageactivated, automatic sampler (set to sample) at prescheduled 6-hour intervals. A suspended-sediment sample was also collected at site 2 each day by an observer for computation of daily loads.

Additional water-quality sampling was conducted to improve definitions of specific water-quality characteristics. These include: four 24-hour dissolved-oxygen surveys, two before and two after channel modifications, at Juniper Branch (site 1) and Chicod Creek (site 2); and the collection of suspended-sediment and related data from November 1979 to January 1982 during selected high-flow periods to define trapping characteristics of two sediment traps constructed on Juniper Branch. The type of data collected, period of record, and frequency of sampling for study sites are listed in table 1 . 


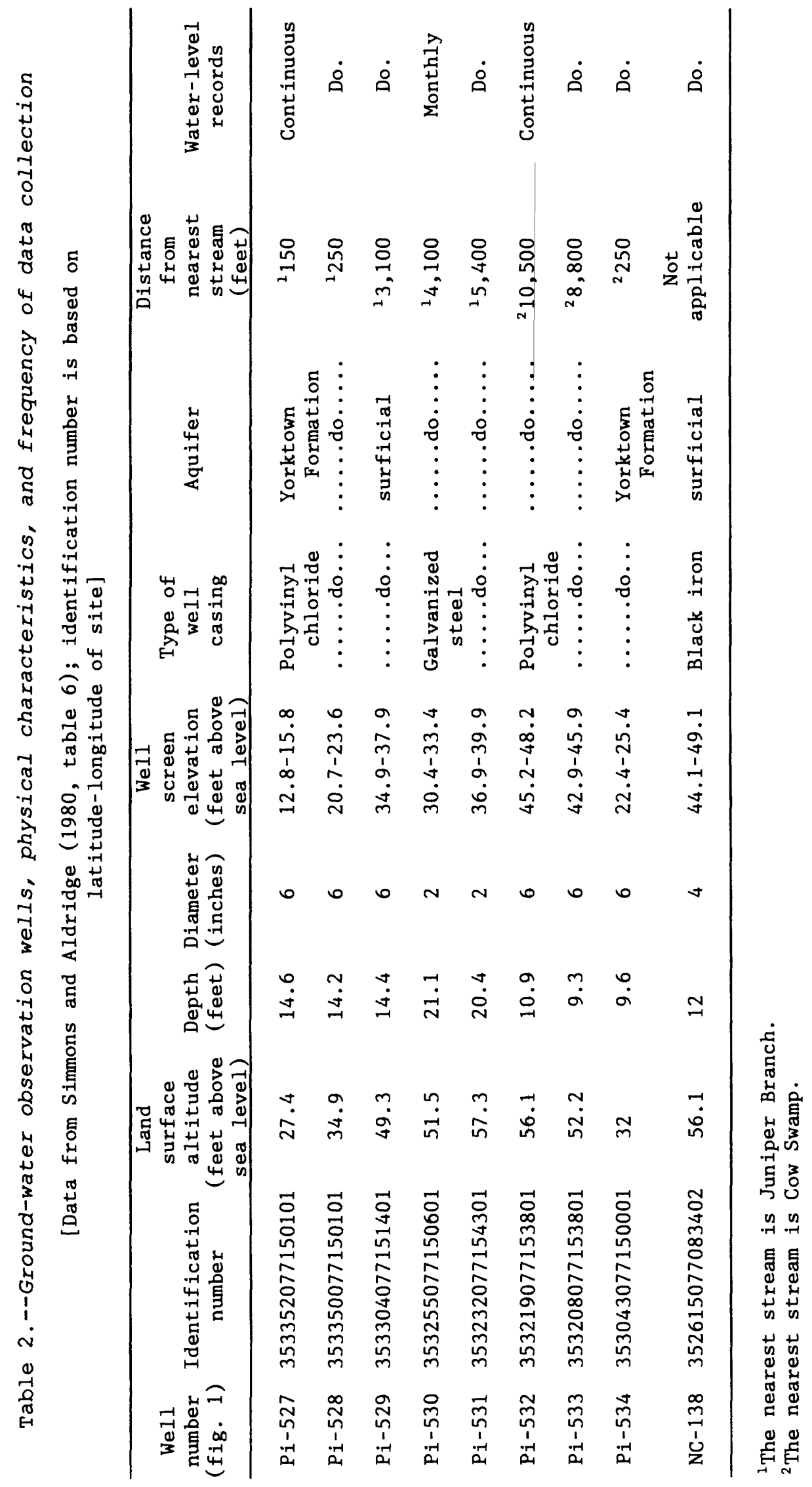


Water-quality samples from observation wells were collected in May 1977 to evaluate overall chemical-quality characteristics of ground water in the study area. These results are reported in Simmons and Aldridge (1980, table 6).

Laboratory and field analyses were made in accordance with methods set forth by the Federal Interagency Work Group (1977) on recommended methods for water-data acquisition. All streamflow and water-quality data collected at study sites are published annually in U.S. Geological Survey WaterResources Data Reports (1976-annually) and can be accessed through the Survey's WATSTORE (Water Data Storage and Retrieval) system (Hutchinson, 1975).

\section{Analytical Approach}

To detect and quantify differences in mean values of hydrologic characteristics directly attributable to channel modifications, a variety of graphical and statistical techniques was used. These techniques were applied hierarchically as shown in figure 5. The first step of the analysis was to graphically evaluate the data on response variables (those hydrologic characteristics suspected of changing as a result of channel modifications) as a function of date and other possible influencing variables to detect trends, changes, and erroneous values. The second step was to statistically summarize groups or subgroups of the response data with respect to the class variable (phase of channel modification) and suspected explanatory variables (year, season of year, discharge or temperature, for example). These simple techniques aided in identifying factors, other than channel modification, which may have influenced the data and which may be used as a control or covariant in a more detailed analysis.

More advanced statistical techniques were used to detect changes and to assess their significance. The next step was to use a covariance model to relate each response variable with explanatory variables. Covariance analysis differs from ordinary regression analysis in that all of the variables within a model do not have to be continuous; a class or factorial variable can be used to identify subgroups of data (Steel and Torrie, 1980). All of the initial covariance models used in this study included a continuous explanatory variable, a class variable representing the phase of channel modification, and the cross product of the explanatory and class variables. The initial covariance models are shown in table 3 . 


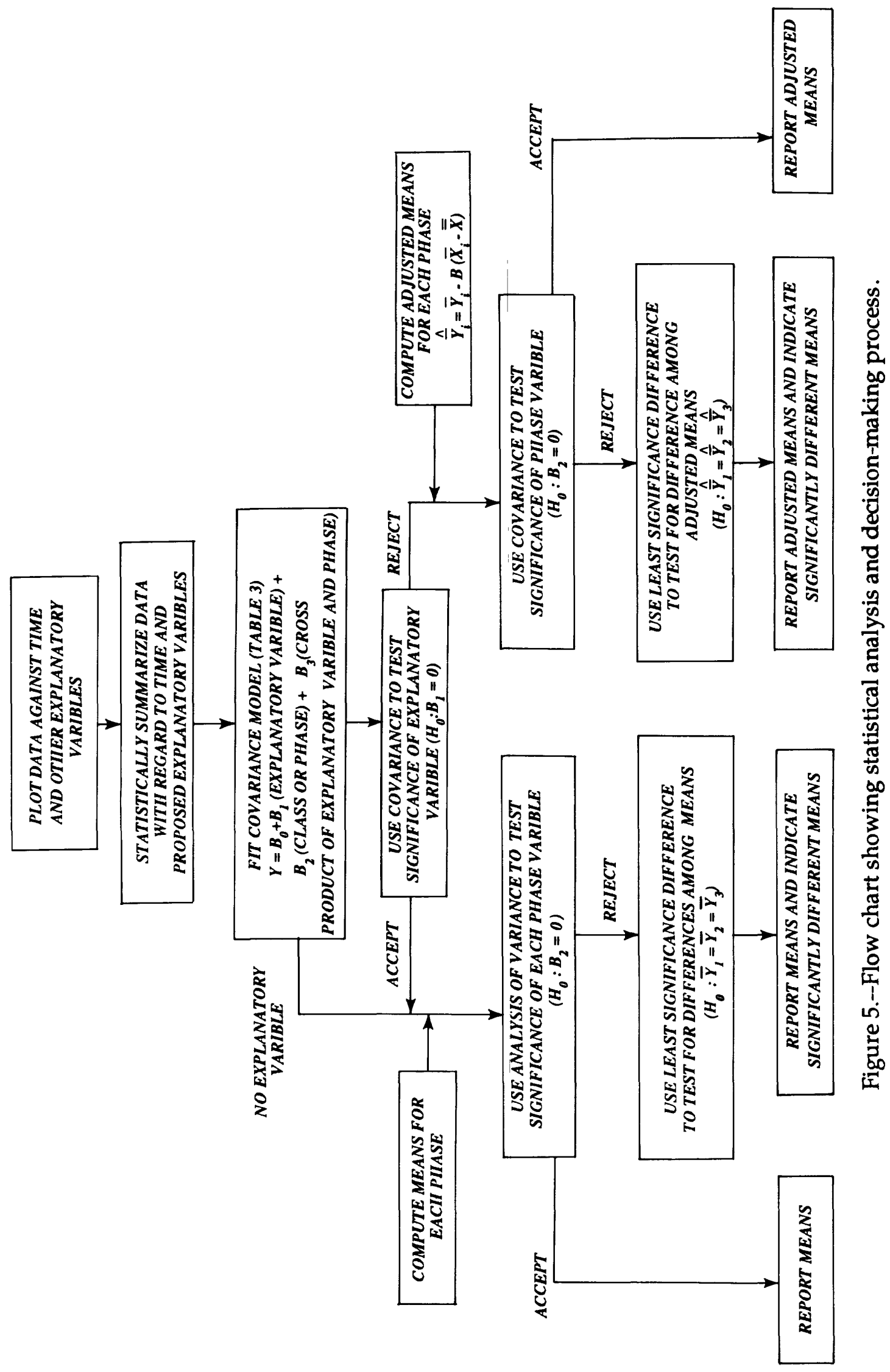




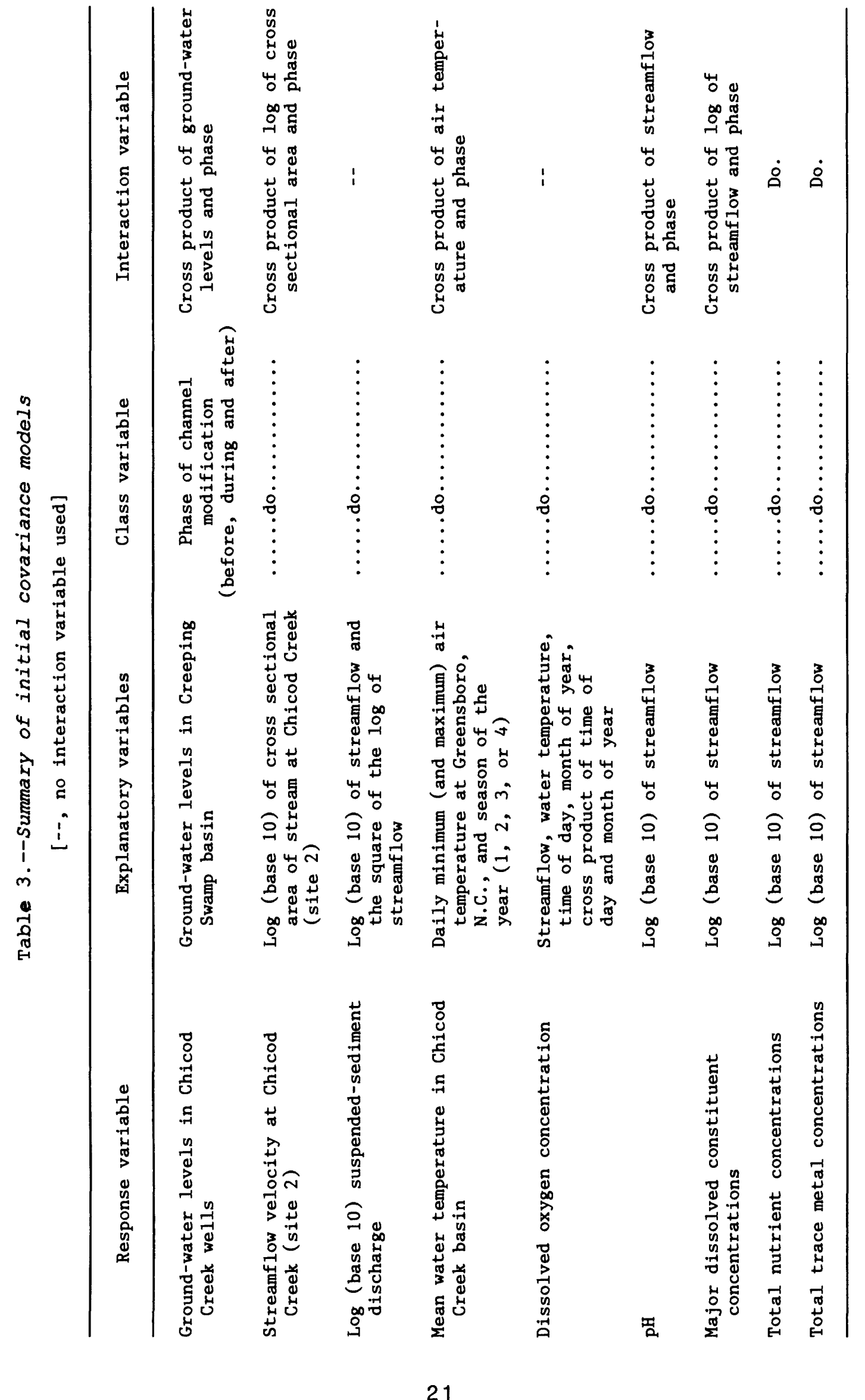


Covariance was then used to determine if fitted parameters representing each of the initial variables were significantly different from zero. If parameter $B_{1}$ (the fitted parameter representing the slope of a relation of the response variable to an explanatory variable) was tested and accepted as being equal to zero, then the response and explanatory variables were not related, and the explanatory variable could be deleted from the model. Once the explanatory variable was deleted the analysis proceeded as an ordinary analysis of variance. The means of the response variable were computed, and parameter $B_{2}$ (the fitted parameter representing the intercepts of the relation of the response and explanatory variable for each phase) was tested to determine if it was significantly different from zero. If the null hypothesis was accepted $\left(B_{2}\right.$ was not significantly different from zero), then there were no significant differences among means from the three phases of channel modification. If the null hypothesis was rejected (B, was significantly different from zero), then differences among means existed and each mean was tested against the others to determine which phase or phases were statistically different from the rest. Testing for differences among means after first rejecting the null hypothesis is equivalent to using Fisher's protected least significant difference (Steel and Torrie, 1980) and adds a measure of conservatism to the analysis.

If the hypothesis that parameter $B_{1}$ was not significantly different from zero was rejected, then the response and explanatory variables were related and the analysis followed a different path (fig. 5). Because differences in the distribution of the explanatory variable during the three phases of the study influenced the distribution of the response variable, the mean of the response variable for each phase was adjusted. The resulting adjusted means are the best estimates of what the means of the response variable for each phase would have been had the mean of the explanatory variable in each phase been equal to the overall mean for the study. The adjusted mean for each phase was given by:

$$
\hat{\mathrm{Y}}_{i}=\overline{\mathrm{Y}}_{\mathbf{i}}-\mathrm{B}\left(\overline{\mathrm{X}}_{\mathbf{i}}-\overline{\overline{\mathrm{X}}}\right)
$$

where: $\hat{\bar{Y}}_{i}$ is the adjusted mean of the response variable for phase $i$;

$\overline{\mathrm{Y}}_{\mathbf{i}}$ is the mean of the response for phase $i$;

$B$ is pooled regression coefficient;

$\bar{x}_{i}$ is the mean of the explanatory variable for phase $i$;

$\overline{\bar{X}}^{1}$ is the mean of the explanatory variable for the study; and

$i$ is the phase of channel modification (before, during, or after). 
The parameter $B_{2}$ was then tested to determine if it was significantly different from zero. If the null hypothesis was accepted ( $B_{2}$ was not significantly different from zero), then there were no significant differences among adjusted means from the three phases of channe1 modification. If the null hypothesis was rejected ( $B_{2}$ was significantly different from zero), then the adjusted means were tested to determine which adjusted mean or means differed from the others.

The results of these statistical tests are summarized in tables throughout the remainder of this report. The occurrence of significant differences among means (either unadjusted or adjusted) are indicated by superscript letters. Where results are termed statistically significant, the level of significance is 0.05 or less. A 0.05 level of significance indicates that there is a 95 -percent chance that an observed difference was caused by something other than random chance.

Data collected in Creeping Swamp basin were used as statistical controls for background conditions in these analyses. However, the use of controls could introduce errors in interpretation if changes in areal weather patterns occurred. To verify that no areal changes in precipitation or temperature patterns occurred during the study period, monthly weather data collected at Greenville, N.C., $12 \mathrm{mi}$ northwest of the study area, and at Kinston, N.C., $30 \mathrm{mi}$ southwest of the study area, were compared before, during, and after channel modifications using a simple covariance analysis (Steel and Torrie, 1980). Neither the intercepts nor the slopes of the resulting relations were significantly different. This indicates that no changes in precipitation or temperature patterns occurred during the study period. Therefore, no climatic changes are apparent that might invalidate the use of data from the control basins.

\section{HYDROLOGIC EFFECTS OF CHANNEL MODIFICATIONS}

Throughout the remainder of this report, the hydrologic conditions in the Chicod Creek basin before, during, and after channel modifications are described and compared in order to quantify the changes that occurred due to channel modifications. The discussions are presented in the order of: surface-water conditions, ground-water conditions, and stream-quality characteristics. The section on stream-quality characteristics considers selected physical and chemical characteristics, pesticides, and bacteria. 


\section{Surface Water}

Extensive channel excavations can substantially alter streamflow characteristics as shown by Heath (1975), Winner and Simmons (1977), and Daniel (1981). In the Chicod Creek basin, the extent of channel modifications differed among individual streams and even along reaches of the same stream (fig. 1). The resulting changes in flow characteristics, such as base flow, streamflow variability, and streamflow velocity, also differed from site to site.

\section{Base-Flow Characteristics}

The excavation of the Juniper Branch channel, the most extensively modified stream in the Chicod basin, increased the amount of base flow to the stream, as depicted by flow-duration graphs at the monitored site on this stream (fig. 6). Prior to channel excavations, daily mean flow at Juniper Branch (site 1) was zero about 6 percent of the time and was less than $0.1 \mathrm{ft}^{3} / \mathrm{s}$ (cubic feet per second) approximately 11 percent of the time. During the modification period, the minimum daily mean flow increased to 0.4 $\mathrm{ft}^{3} / \mathrm{s}$ and was less than $0.9 \mathrm{ft}^{3} / \mathrm{s}$ only 11 percent of the time. This increase in base flow occurred even though most of the Coastal Plain, including the study area, was affected by a drought from July 1980 to early March 1981. (The rainfall deficiency at Greenville, N.C., was more than 10 inches during that period.) After modifications were completed, base flow at site 1 was observed to have decreased slightly; however, daily flow was zero less than 0.1 percent of the time ( 5 out of 1,825 days), and base flow was nearly $0.9 \mathrm{ft}^{3} / \mathrm{s} 11$ percent of the time. This minor decrease may be attributed to normal, random climatic variations.

Base flow also increased at site 2 on Chicod Creek as a result of modifications ( $f i g .6$ ). Before modifications, base flow was less than 0.1 $\mathrm{ft}^{3} / \mathrm{s}$ about 13 percent of the time and commonly ceased to flow. During channel modifications, base flow was less than $0.1 \mathrm{ft}^{3} / \mathrm{s}$ only 6 percent of the time or less than half as often as before modifications; after modifications, flow was less than $0.1 \mathrm{ft}^{3} / \mathrm{s}$ about 3 percent of the time, showing a further slight increase in base flow.

Flow-duration curves were developed for Creeping Swamp (site 5). The curves (fig. 6) were for the pre-excavation period (October 1975 to September 1978), the period when excavation was in progress in Chicod basin 


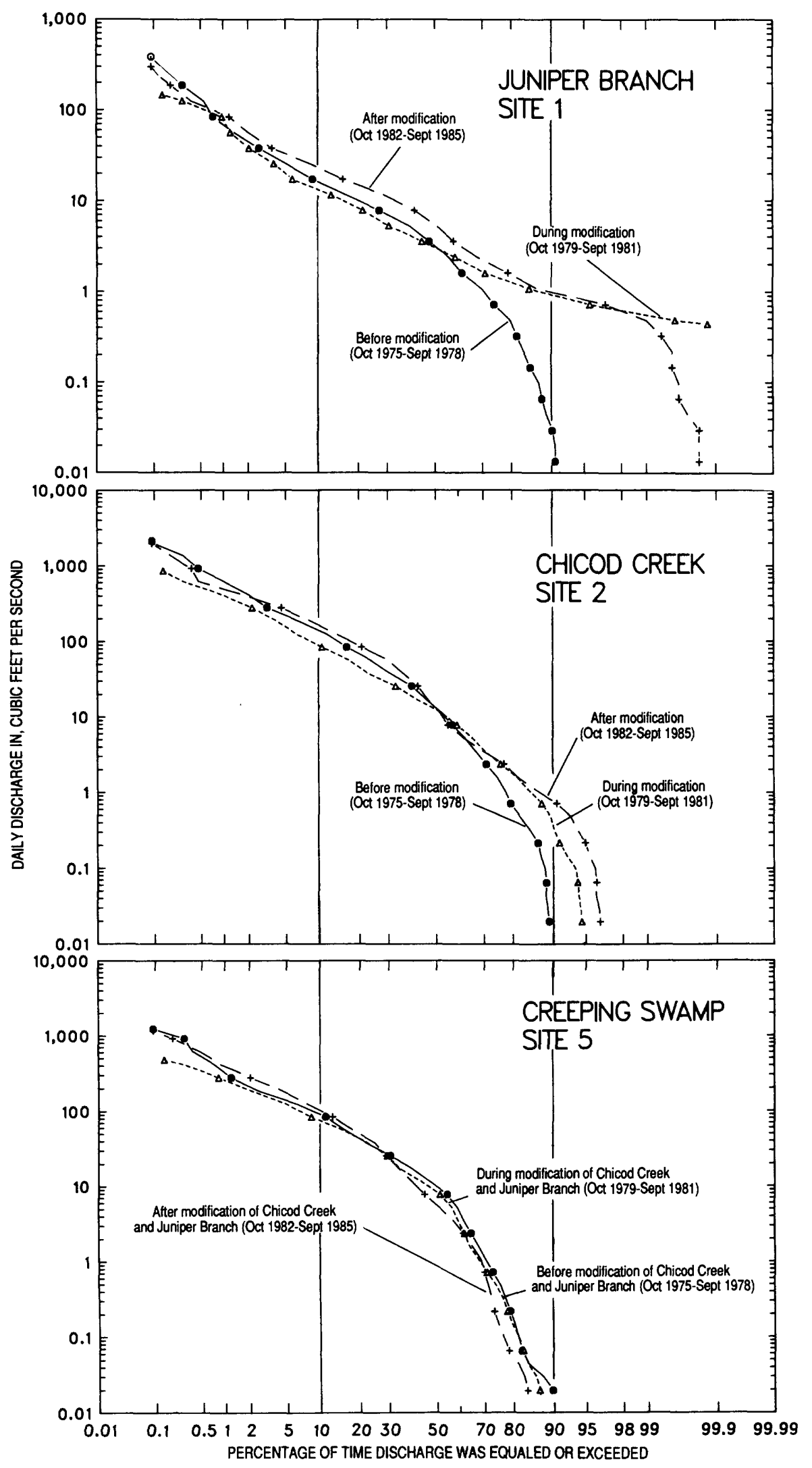

Figure 6.--Flow-duration curves for Juniper Branch and Chicod Creek before, during, and after modifications and for Creeping Swamp during concurrent periods. 
(October 1979 to September 1981), and the post-excavation period (October 1982 to september 1985). The three curves are virtually paralle1, indicating that no redistribution of flow occurred at this site during the study.

\section{Streamflow Variability}

A second, though perhaps less obvious, change in streamflow characteristics after channel modification is a reduction in streamflow variability. Lane and Lei (1950) introduced an index of streamflow variability (Lane's variability indexes), which defined the standard deviation of the logarithms (base 10) of flows corresponding to 10 -percent intervals from 5 percent to 95 percent of the time on the flow-duration curve. This statistic is more sensitive to variation in low and moderate flows than in high or peak flows. The lower the index, the lower the flow variability.

At Juniper Branch (site 1), the variability index was 0.87 before modifications (table 4). During modifications, the variability index was 0.42 , increasing slightly to 0.49 in the period after modification. At Chicod Creek (site 2), the index fell from 1.24 to 0.85 during modification and dropped slightly to 0.80 after modification. At Creeping Swamp (site 5 ), the index varied slightly through the three periods ending with an overal1 increase.

Table 4.--Lane's variability index at Juniper Branch (site 1) and Chicod Creek (site 2) before, during, and after channel modifications and at unmodified Creeping Swamp (site 5) for concurrent periods

\begin{tabular}{lccc}
\hline & Juniper Branch & Chicod Creek & Creeping Swamp \\
\hline Before modification & 0.87 & 1.24 & 1.23 \\
During modification & .42 & .85 & 1.14 \\
After modification & .49 & .80 & 1.31 \\
\hline
\end{tabular}

The reduction in streamflow variability is directly related to channel modification. After stream modification, ground-water discharge to the stream may increase; base flow is more sustained, and streamflow variability is thereby reduced. The decrease in streamflow variability could have important ecological implications as the biological community recovers from the channel disturbance (Resh and others, 1988). 
Hydraulic and Flood Characteristics

Increased drainage efficiency of stream channels and reduced flooding of low-lying areas was the third major change in surface-water conditions as a result of channel modifications. Prior to excavation, runoff from minor storms exceeded the carrying capacities of the poorly defined channels in the Chicod Creek basin. The flood plains stored and attenuated floodwaters. Water levels rose slowly and flood crests lasted for hours before receding. The stream channels' limited capacities to drain floodwaters also caused recessions to be slow, and flood plains were sometimes inundated for days or weeks after a flood.

Channe1 excavation and, to a lesser extent, clearing and snagging altered the timing, duration, and magnitude of flooding. The deeper, more hydraulically efficient channels could convey larger discharges before their capacities were exceeded and flood plains were inundated less frequently after modifications than before. Water levels rose faster and flood crests were sharper and higher. An indication of the extent of these changes can be developed from comparisons of before-and after-modification channel capacity with the magnitude of high flows observed during storms.

Prior to modification, stream channels in the Chicod Creek basin were shallow, braided, and poorly defined. The channel at site 4 was typical of this condition even after clearing and snagging (fig. 7), as was the Juniper Branch channel in the reach adjacent to observation we11 Pi-527 prior to modification ( $f i g .8$ ). According to sCS construction documents, the unmodified streambed of Juniper Branch was generally less than $0.5 \mathrm{ft}$ lower than the surrounding flood plain. Typical widths of the channel ranged from 2 to $12 \mathrm{ft}$. The conveyance of the channel was sma11, probably ranging from 2 to $10 \mathrm{ft}^{3} / \mathrm{s}$ and was frequently exceeded by minor floods (Coffey, 1982). Mean flows exceeded $10 \mathrm{ft}^{3} / \mathrm{s}$ at site 1 on more than 155 days or 20 percent of the time (fig. 6) before modification.

Excavation of the stream channel altered this condition. On the basis of SCS construction drawings, the excavated Juniper Branch channel in the reach near well $\mathrm{Pi}-527$ ( $\mathrm{fig}$. 8) could accommodate, within its banks, a flow of approximately $88 \mathrm{ft}^{3} / \mathrm{s}$. Adjusting this flow using the ratio of the drainage area above this reach to that of site $1\left(7.50 \mathrm{mi}^{2} / 6.58 \mathrm{mi}^{2}\right)$ and comparing this adjusted flow $\left(100 \mathrm{ft}^{3} / \mathrm{s}\right)$ to peak streamflows at site 1 reveals that the capacity of the excavated channel in the reach near Pi-527 was probably exceeded 9 times during modification; daily mean flows at site 1 exceeded $100 \mathrm{ft}^{3} / \mathrm{s}$ on 5 days or 0.5 percent of the time during modification ( $f i g .4$ ). 


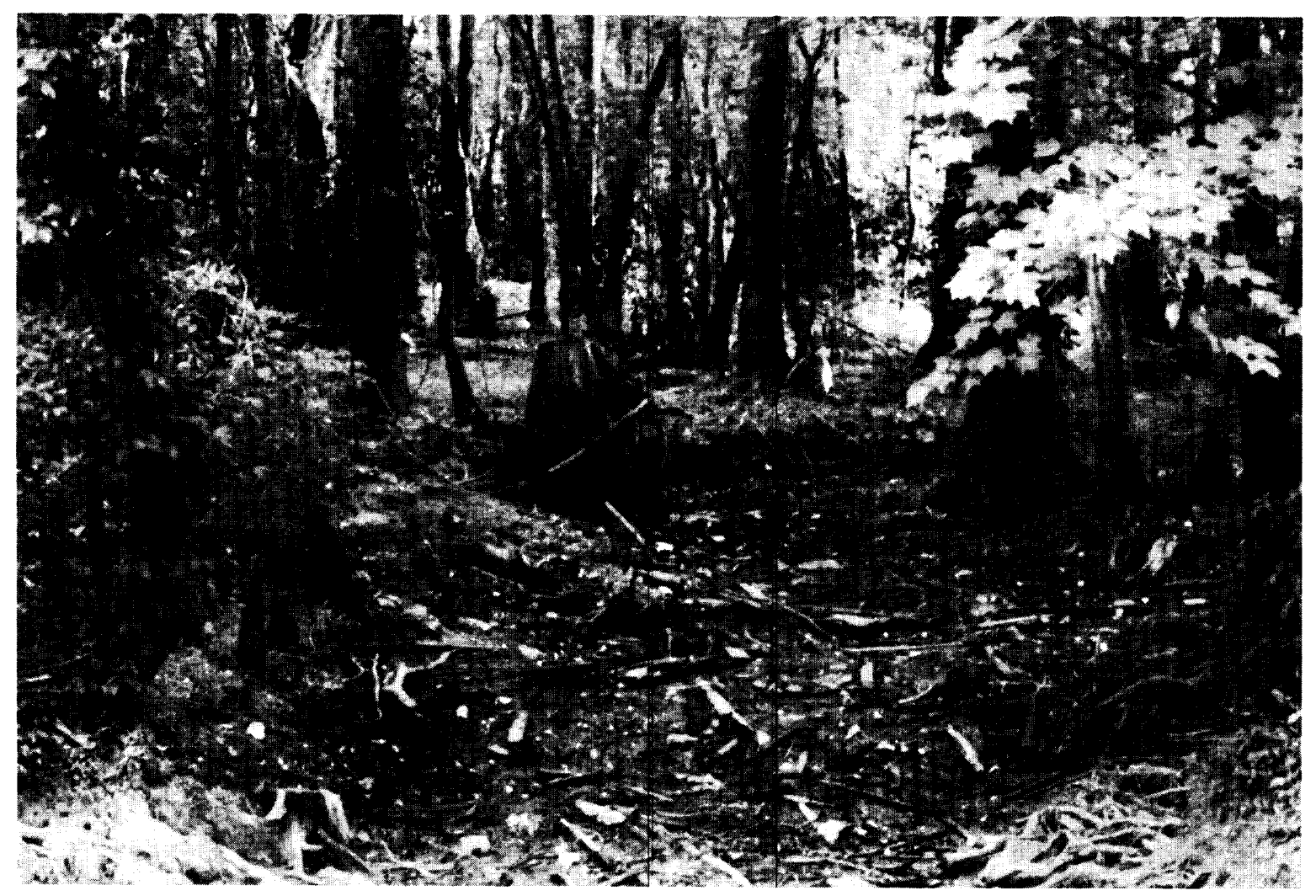

Figure 7.--Stream channel at Chicod Creek (site 4) after clearing and snagging operations.

(Photograph by J. Kent Crawford, U.S. Geological Survey)

In the period after modification the channel capacity decreased 50 percent but remained substantially above estimated capacity before modification. A survey of the Juniper Branch channel adjacent to Pi-527 in August 1987 showed that the channel could accommodate a flow of about $44 \mathrm{ft}^{3} / \mathrm{s}$ within its banks. This corresponds to a flow of $50 \mathrm{ft}^{3} / \mathrm{s}$ at site 1 , which, as a daily mean flow, was exceeded 36 days or 2 percent of the time during the remainder of the study. Parts of the Juniper Branch flood plain that were commonly inundated before modification were only infrequently inundated afterwards.

Channel modifications such as clearing and snagging also altered storm runoff characteristics. These operations increased channel conveyance by removing obstructions and by reducing channel roughness. The hydraulic effects of these changes, including higher streamflow velocities, were detected at Chicod Creek (site 2). Modifications immediately upstream and downstream of site 2 consisted entirely of clearing and snagging (fig. 1). 


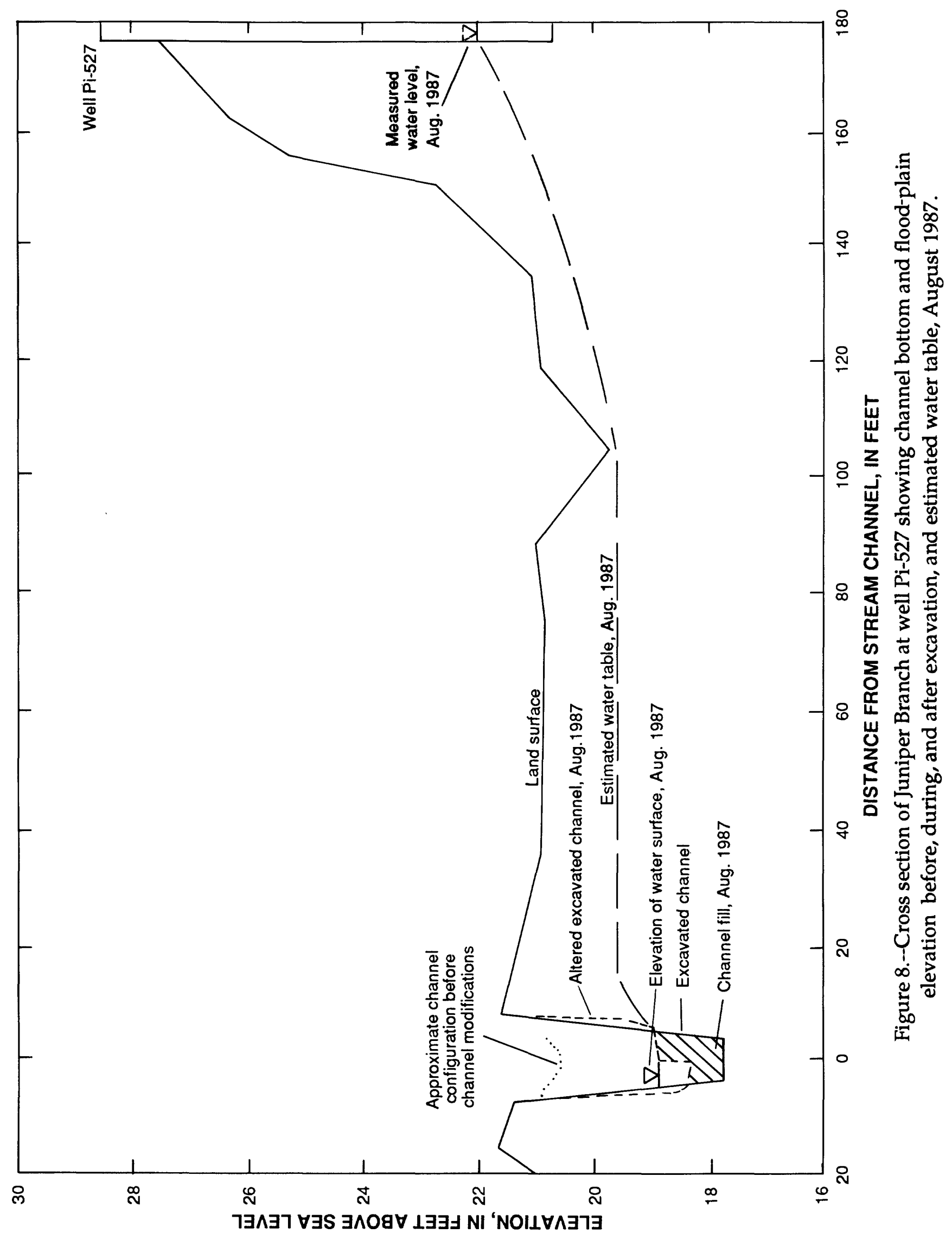


At site 2, a stable channel cross section, lined with concrete, was constructed to facilitate measurement of streamflow and streamflow velocity. No changes in channel geometry occurred at the site during the study. However, streamflow velocity was mostly greater after channel modifications upstream and downstream of the site than before (fig. 9). For instance, before modifications the velocity corresponding to a cross-sectional area of $10 \mathrm{ft}^{2}$ was $0.4 \mathrm{ft} / \mathrm{s}$. After modifications, the velocity for the same crosssectional area was $1.5 \mathrm{ft} / \mathrm{s}$.

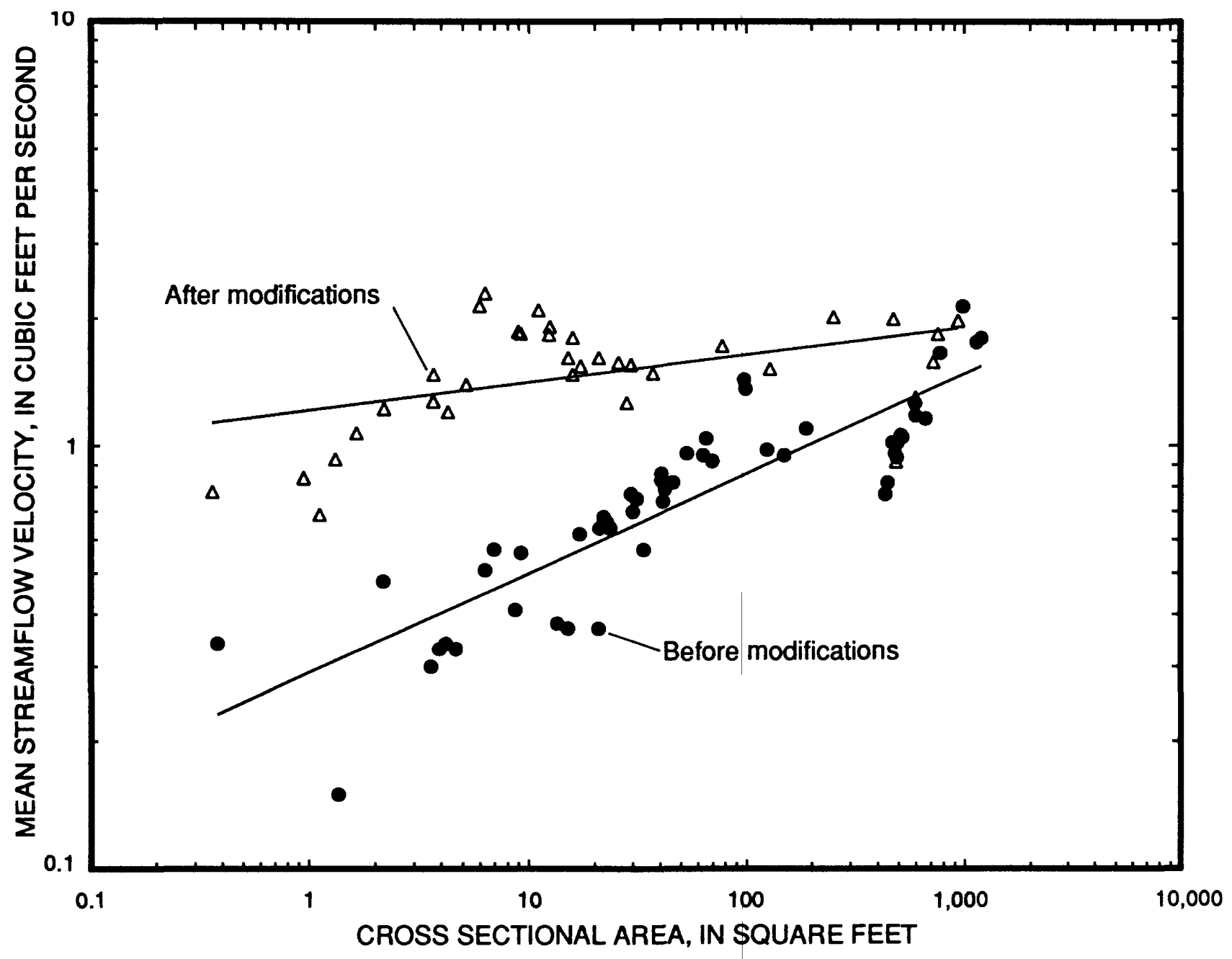

Figure 9.--Measured mean streamflow velocity as a function of stream crosssectional area at Chicod Creek (site 2) before and after downstream channel modifications.

The slopes of the two velocity relations at site 2 also were different. As shown in figure 9, streamflow velocity increases were greatest in the low cross-sectional area (within the main channel), whereas velocity increases 
were less in the high cross-sectional area (overbank flow). This tendency is consistent with how clearing and snagging modifications were accomplished in and around the stream channel. Only the channel bottoms and sides were cleared or snagged; no changes were made to the overbank part of the flood plain. Therefore, streamflow velocity during low and medium discharge was higher after modifications than before, but water flowing over the banks during high flows at site 2 was impeded just as it was before modifications.

An indication of how the excavation and clearing and snagging affected flood timing and duration can be seen by examining the flood hydrograph data collected for Chicod Creek, Juniper Branch, and Creeping Swamp. Although flood-producing storms over the study area were highly variable both spacially and temporally, statistical comparisons of certain hydrograph characteristics of the three streams for floods recorded before and after channel work can give a qualitative assessment of any changes in flood timing and duration due to the channel modifications. The effects of channel modifications on flood magnitudes can also be deduced.

Statistical comparisons of flood durations (hydrograph widths) are given in table 5. For the purpose of this comparison, hydrograph width is defined as the duration that the stream discharge remains higher than a value that corresponds to 75 percent of the peak flow (fig. 10).

Table 5.--Summary of streamflow hydrograph widths (in hours) at 75 percent of peak flows at Juniper Branch (site 1) and Chicod Creek (site 2) before, during, and after modifications and at unmodified Creeping Swamp

(site 5) for concurrent periods

$[\mathrm{N}$, number of samples]

\begin{tabular}{|c|c|c|c|c|c|c|c|c|c|c|c|c|}
\hline \multirow{3}{*}{ Site } & \multicolumn{12}{|c|}{$\begin{array}{c}\text { Mean }^{1} \text { and median hydrograph widths and standard deviation } \\
\text { (hours) }\end{array}$} \\
\hline & \multicolumn{4}{|c|}{ Before modification } & \multicolumn{4}{|c|}{ During modification } & \multicolumn{4}{|c|}{ After modification } \\
\hline & Mean & Median & $\begin{array}{l}\text { Standard } \\
\text { deviation }\end{array}$ & $\mathbf{N}$ & Mean & Median & $\begin{array}{l}\text { Standard } \\
\text { deviation }\end{array}$ & $\mathrm{N}$ & Mean & Median & $\begin{array}{l}\text { Standard } \\
\text { deviation }\end{array}$ & $N$ \\
\hline $\begin{array}{l}\text { Juniper } \\
\text { (site } 1)\end{array}$ & $6.4^{a}$ & 5 & 2.6 & 7 & $3.2^{\mathrm{b}}$ & 3 & 0.38 & 9 & $4.4^{\mathrm{a}}$ & 3 & 1.5 & 30 \\
\hline $\begin{array}{l}\text { Chicod } \\
\text { Creek } \\
\text { (site 2) }\end{array}$ & $22^{a}$ & 22 & 8.7 & 17 & $14.7^{\mathrm{b}}$ & 13 & 6.9 & 11 & $14.2^{b}$ & 14 & 5.5 & 39 \\
\hline $\begin{array}{l}\text { Creeping } \\
\text { Swamp } \\
\text { (site 5) }\end{array}$ & $46^{a}$ & 48 & 18 & 7 & $52^{a}$ & 56 & 10 & 3 & $46.3^{a}$ & 46 & 15 & 10 \\
\hline
\end{tabular}

\footnotetext{
${ }^{1}$ Hydrograph widths at sites with the same letter are not significantly different from one another at the 95-percent confidence level as determined by the Student's t-test; those with different letters are significantly different from one another. For example, there are no statistically significant differences among hydrographs for the three phases of channel modification at site 5; whereas, hydrograph widths before modification are significantly different from hydrograph widths during and after modification at site 2 .
} 


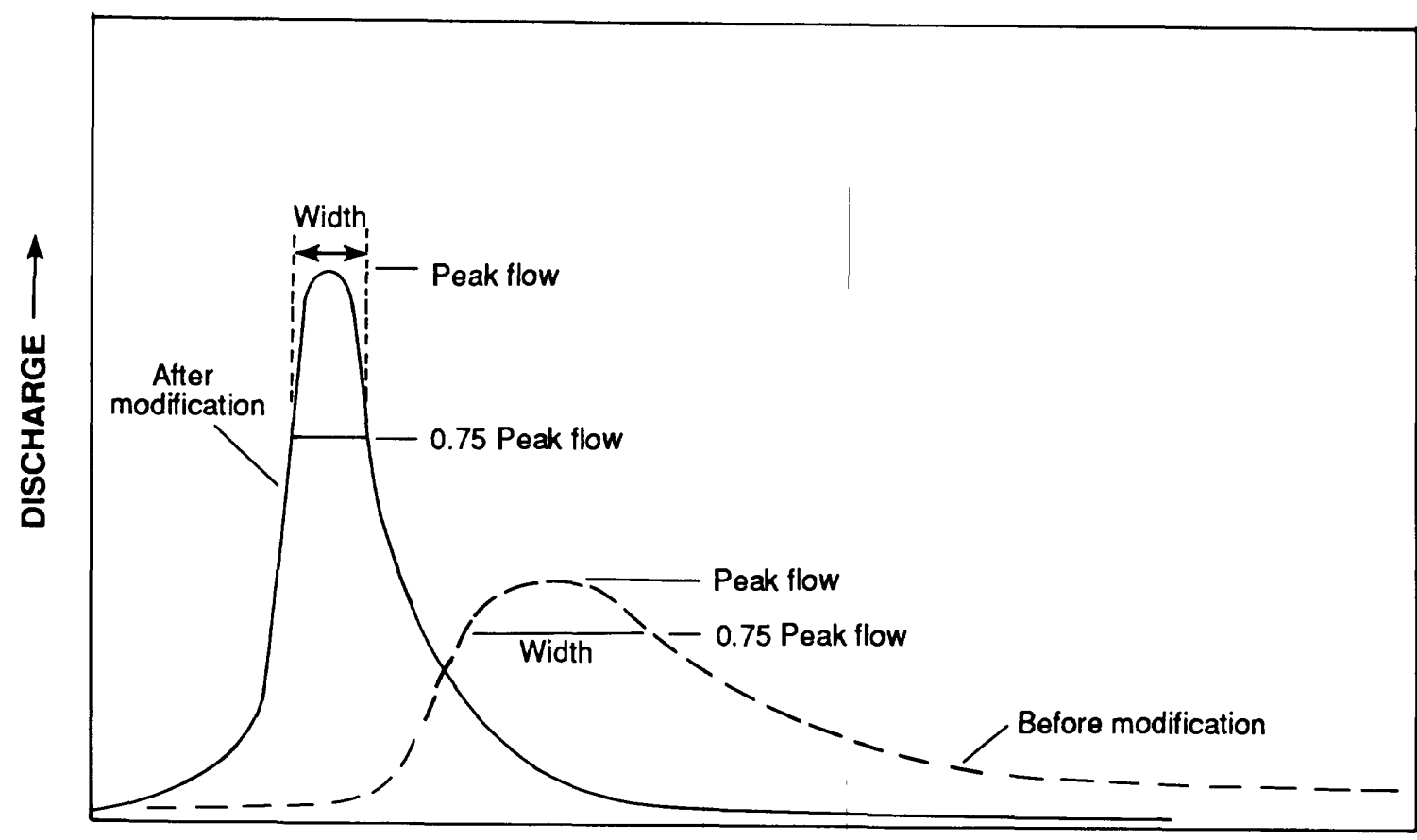

TIME $\longrightarrow$

Figure 10.--Diagram showing hypothetical widths of hydrographs at peak flow and at 75 percent of peak flow before and after channel modifications.

After channel modifications, storm hydrographs at Juniper Branch and Chicod Creek generally were narrower than hydrographs before modifications. Before modifications the mean width at Juniper Branch was 6.4 hours. After modifications, the width was 4.4 hours; however, this difference was not statistically significant at the 95-percent confidence level using the Student's t-test. At Chicod Creek (site 2), the width of the hydrograph declined from 22 hours before modifications to 14.2 hours after modifications, a difference that was significant at the 95-percent level. No differences were detected at the control site, Creeping Swamp (site 5). The width was 46 hours before modification of Chicod Creek and 46.3 hours afterwards, supporting conclusions that the differences in hydrograph widths at the modified sites were due to channel modifications.

Because the hydrograph widths are narrower after channel modifications than before, it follows that flood flows peak more rapidly and are of shorter duration. Assuming that the volume of runoff produced by a given storm of great intensity is the same after modification as it was before modification, the shorter flood duration should produce peak flows that are greater after modification than before. 
Throughout the study, runoff periods consistently peaked at Juniper Branch and Chicod Creek before they did at Creeping Swamp. Noting the differences in the timing of peak flows at Juniper Branch and Chicod Creek from that of the peak flow at Creeping Swamp during concurrent storms before, during, and after modifications provides a comparative measure of changes in timing of peak flows after channel modifications (table 6). Before modification, Juniper Branch reached peak flow an average of 24.3 hours before Creeping Swamp. After modification, Juniper Branch peaked more quickly, an average of 37 hours before Creeping Swamp. At Chicod Creek, peaks occurred 13.7 hours prior to Creeping Swamp before modification but increased to an average of 20.7 hours earlier than Creeping Swamp after modification. The increase at Juniper Branch was statistically significant at the 95-percent level; the increase at Chicod Creek was not.

Table 6.--Summary of lag (in hours) between occurrence of peak flows at Juniper Branch (site 1) and Chicod Creek (site 2) and occurrence of peak flow at unmodified Creeping Swamp (site 5)

$[N$, number of samples]

\begin{tabular}{|c|c|c|c|c|c|c|c|c|c|c|c|c|}
\hline \multirow{3}{*}{ Site } & \multicolumn{12}{|c|}{$\begin{array}{c}\text { Mean }^{1} \text {, median, and standard deviation of lag } \\
\text { (hours) }\end{array}$} \\
\hline & \multicolumn{4}{|c|}{ Before modification } & \multicolumn{4}{|c|}{ During modification } & \multicolumn{4}{|c|}{ After modification } \\
\hline & Mean & Median & $\begin{array}{l}\text { Standard } \\
\text { deviation }\end{array}$ & $\mathrm{N}$ & Mean & Median & $\begin{array}{l}\text { Standard } \\
\text { deviation }\end{array}$ & $\mathrm{N}$ & Mean & Median & $\begin{array}{l}\text { Standard } \\
\text { deviation }\end{array}$ & $\mathrm{N}$ \\
\hline $\begin{array}{c}\text { Juniper } \\
\text { Branch } \\
\text { (site 1) }\end{array}$ & $24.3^{a}$ & 22 & 17 & 23 & $28.4^{a b}$ & 23 & 16 & 14 & $37^{b}$ & 35 & 21.1 & 25 \\
\hline $\begin{array}{l}\text { Chicod } \\
\text { Creek } \\
\text { (site 2) }\end{array}$ & $13.7^{a}$ & 14 & 8.4 & 6 & $32.7^{b}$ & 32 & 6 & 3 & $20.7^{a b}$ & 20 & 9.1 & 9 \\
\hline
\end{tabular}

lMean lags at sites with the same letter are not significantly different from one another at the 95-percent confidence level as determined by the Student's t-test; those with different letters are significantly different from one another. For example, there is no significant difference in mean lag at site 1 before modification compared to during modification; nor is there a significant difference between mean lags during and after modification; whereas, there is a significant difference between mean lags before and after modification.

\section{Ground Water}

Channel modification in the form of excavations in the Chicod Creek basin had some effects on ground-water conditions with respect to groundwater movement through the system, ground-water levels, and base flow. Such effects are best described by first examining some conclusions from data collected in similar Coastal Plain basins. On the basis of data from the 
channelized Ahoskie Creek, Winner and Simmons (1977) observed no change in the total runoff from the Ahoskie Creek basin after channel modifications as shown in their comparison of cumulative rainfall and runoff.

A potential redistribution of the amount of water in the ground-water components of the water budget in Creeping Swamp basin was discussed by Winner and Simmons (1977) as an anticipated result of proposed channel modifications there. The major effect is an increase in water moving through the ground-water system, as part of the shallow aquifer near the channelized stream is dewatered as a result of lower stream stages. When the stream channel is lowered, the water level in the channel is also lowered, especially during base-flow periods. The hydraulic head at the stream is the controlling low head at the ground-water discharge area, which is the stream. This lowered head causes the ground-water gradient to increase toward the stream which, in turn, temporarily results in greater ground-water discharge (base flow). This process also allows an additional part of the shallow aquifer to be dewatered during base-flow periods (fig. 11). During the next recharge event, part or all of the shallow aquifer may be refilled to start a new cycle. The additional recharge is furnished by a reduction in overland runoff (Winner and Simmons, 1977).

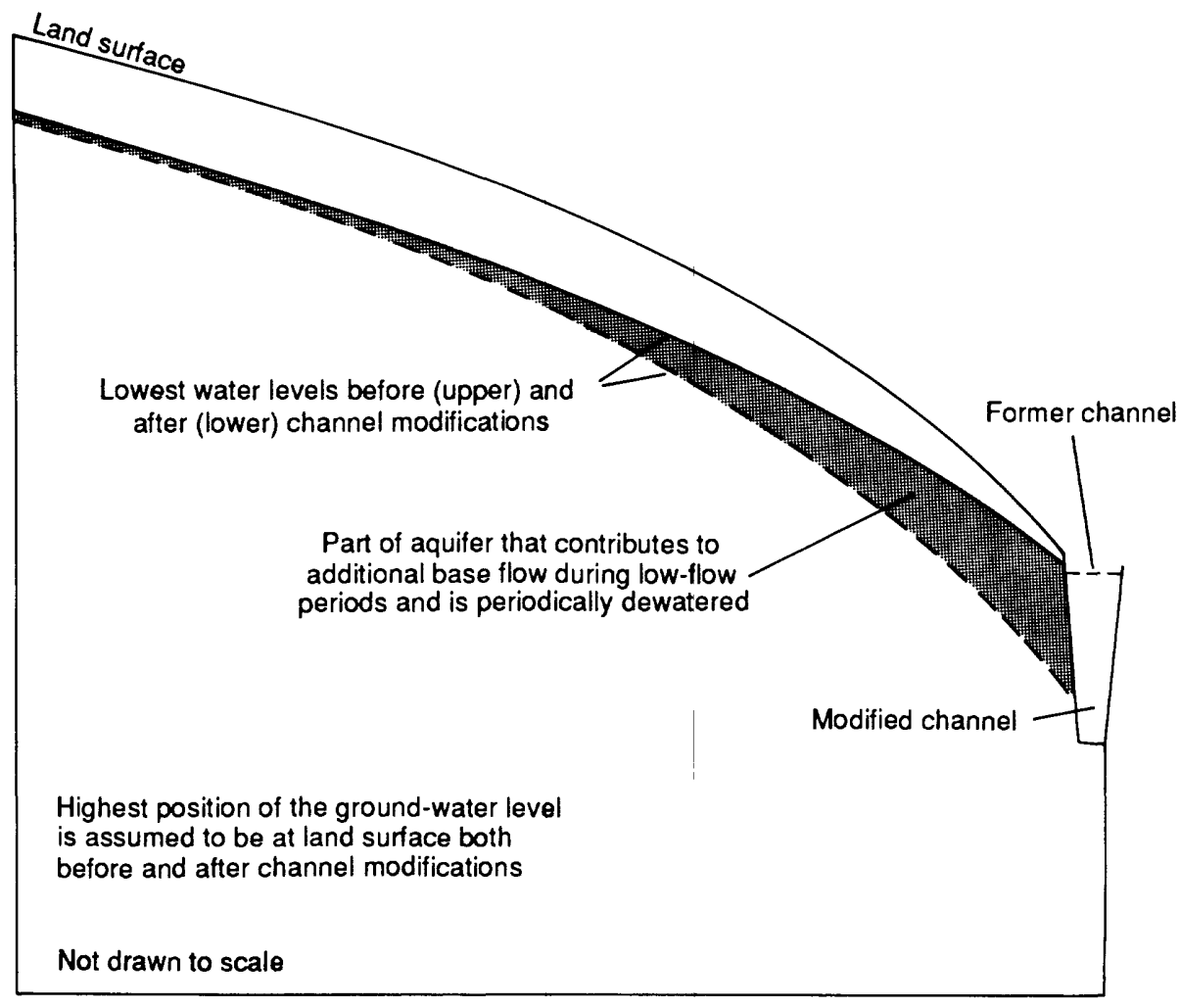

Figure 11.--Drainage of surficial aquifer after channel modification (from Winner and Simmons, 1977). 
If the increase in base flow results from increased ground-water discharge, a greater range in ground-water level fluctuation is expected after the channels are deepened with the greatest change in amplitude occurring near the stream and relatively little or no change in amplitude occurring farther away from the channel (fig. 11). Depending on aquifer characteristics, such as hydraulic conductivity and thickness, and on the extent of channel excavation, the changes in ground-water levels may be undetectable more than a few hundred feet from the stream. Simmons and Watkins (1982) observed declines of ground-water levels that fit this situation after excavation of the Black River near Dunn, North Carolina. After more than $2 \mathrm{ft}$ of channel excavation, ground-water levels near the stream declined an amount inversely proportionate to distance from the stream. At a well 500 feet from the stream, no change was detected.

Three aspects of Chicod Creek basin water budget, as discussed above-total runoff, ground-water levels, and base-flow contributions--were investigated during this study to determine how these were changed by channel modifications in this basin. A double-mass curve (fig. 12) reveals that the relation between cumulative rainfall and cumulative runoff at Juniper Branch remained unchanged after modifications, which began in mid-

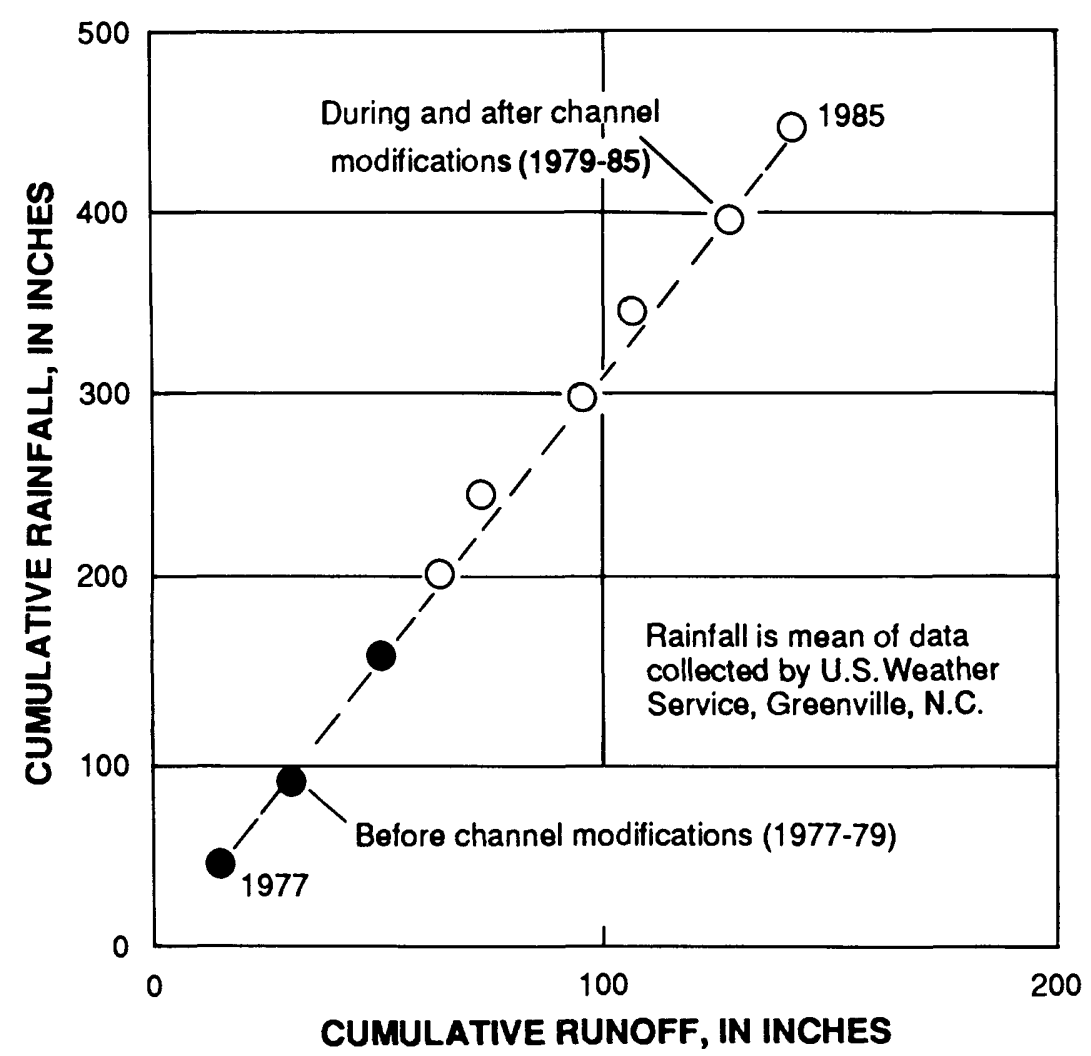

Figure 12.--Cumulative rainfal1-runoff relation for Juniper Branch, 1977-85. 
1979. Thus, channel modifications did not change the rainfall-runoff relation in the Juniper Branch part of the Chicod Creek basin.

Observation wells in the study area were used to monitor ground-water levels in the surficial aquifer before, during and after modifications to detect any ground-water level changes. However, annual precipitation in the study area during 1976-87 ranged from about 39 to 64 in. per year, and a comparison of the position of the water table during those years might be more indicative of variations in ground-water recharge resulting from variations in rainfall than of those caused by channel modifications. Comparison of water-level records at selected wells in the Chicod Creek basin with those of wel1 NC-138 in the Creeping Swamp control basin provided an account of water-level changes that were caused by channel modifications (table 7).

In order to separate climatic influences on ground-water levels in the Chicod Creek basin from those attributable to channel modifications, groundwater level data from the Chicod Creek basin during base-flow periods before, during, and after modifications were subjected to an analysis of covariance (Steel and Torrie, 1980) using concurrent ground-water level data from the control well, NC-138, as the independent or explanatory variable. Statistically significant differences in water levels among the three periods were detected at wells Pi-527, Pi-528, Pi-532, and Pi-533 (Watkins and Simmons, 1984).

The mean ground-water levels for each phase of the project at each of these wells were then adjusted to estimate what each mean would have been if the climatic conditions had been the same in all three phases of the project. The adjusted means are shown in table 8 . Tests of these adjusted mean ground-water levels (Steel and Torrie, 1980) in wells Pi-527, $150 \mathrm{ft}$ from Juniper Branch, and $\mathrm{Pi}-528,250 \mathrm{ft}$ from the stream, indicate statistically significant declines of 0.4 and $0.2 \mathrm{ft}$, respectively, during modification. Essentially, these are the same results as those obtained by Watkins and Simmons (1984) and are consistent with the pattern of waterlevel declines presented by Winner and Simmons (1977) as illustrated in figure 11 .

After channel modification, the mean ground-water levels in wells $\mathrm{Pi}$ 527 and $\mathrm{Pi}-528$ returned to levels slightly higher than levels before modification, an indication that adjustments against the ground-water levels in NC-138 may not have totally removed the effect of the climate on groundwater levels. At least a part of the during-modification phase of the study 


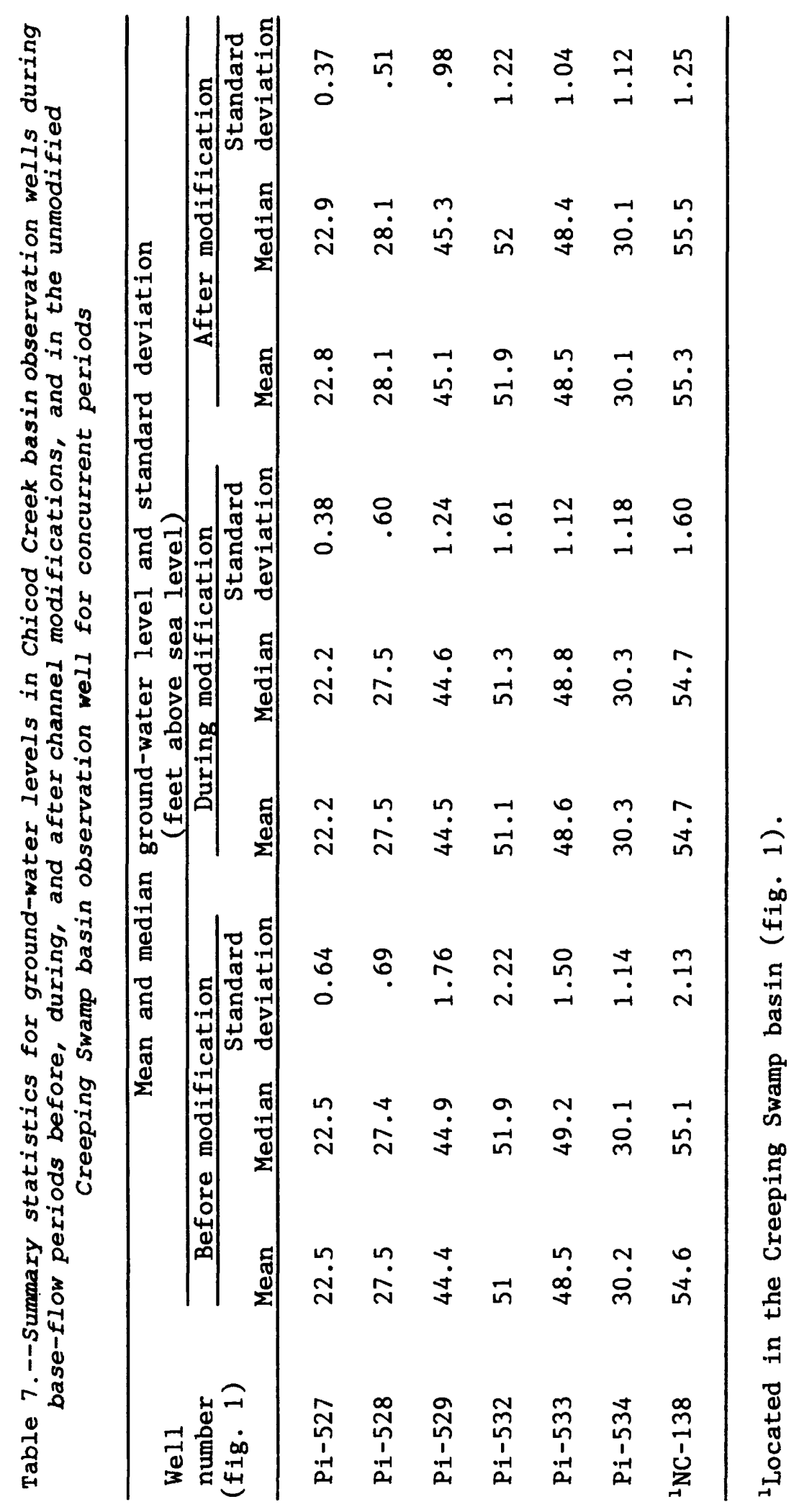


occurred during a severe drought as was previously mentioned, whereas the period after modification was wetter than normal, as indicated by the rises in mean water levels in most of the wells and in the control well, NC-138 (table 7).

Table 8.--Mean ground-water levels in Chicod Creek basin observation wells during base-flow periods before, during, and after channel modifications after adjustment for climatic effects (modified from Watkins and Simmons, 1984)

\begin{tabular}{cccc}
\hline \multirow{2}{*}{$\begin{array}{c}\text { Well } \\
\text { (fimber }\end{array}$} & Adjusted mean & ground-water leve1 ${ }^{1}$ (feet above sea leve1) \\
\cline { 2 - 4 } & $\begin{array}{c}\text { Before } \\
\text { modification }\end{array}$ & $\begin{array}{c}\text { During } \\
\text { modification }\end{array}$ & $\begin{array}{c}\text { After } \\
\text { modification }\end{array}$ \\
\hline Pi-527 & $22.7^{\mathrm{a}}$ & $22.3^{\mathrm{b}}$ & $22.7^{\mathrm{a}}$ \\
$\mathrm{Pi-528}$ & $27.6^{\mathrm{a}}$ & $27.4^{\mathrm{b}}$ & $27.7^{\mathrm{c}}$ \\
$\mathrm{Pi-532}$ & $51.5^{\mathrm{a}}$ & $51.4^{\mathrm{a}}$ & $51.6^{\mathrm{b}}$ \\
$\mathrm{Pi-533}$ & $48.8^{\mathrm{a}}$ & $48.7^{\mathrm{a}}$ & $48.6^{\mathrm{b}}$ \\
\hline
\end{tabular}

${ }^{1}$ Mean ground-water levels at wells with the same letter are not significantly different from one another at the 95-percent confidence level as determined by Fisher's protected least significant difference test. Those with different letters are significantly different from one another. For example, mean ground-water levels at $\mathrm{Pi}-527$ before and after channel modifications are not significantly different; whereas, the mean ground-water level before modification is significantly different from the mean ground-water level during modification.

An analysis of flow duration for channelized Juniper Branch and Chicod Creek for the three periods of the study reveals a change in base flow of the two streams after modifications of their channels (fig. 6). Base flow in Juniper Branch increased during modification, but has decreased somewhat in the after-modification period. This decrease in base flow is consistent with the after-modification filling of the Juniper Branch channel and the consequent rise in mean ground-water levels during base-flow periods in we11s $\mathrm{Pi}-527$ and $\mathrm{Pi}-528$.

As shown or predicted in other studies, channel modifications in the Juniper Creek basin did affect the ground-water contributions to streamflow, although the changes were minor, limited to areas near the stream, and likely temporary. Total runoff from the basin was not changed, but the amount of water moving through the ground-water system increased during channel modifications, especially near the excavated reaches of the streams. 
Ground-water levels were temporarily lowered near the channel during low flow because of lowered stream stage and increased base flow.

\section{Stream Quality}

Stream quality in the Chicod Creek basin is influenced by existing geochemical conditions, quality of precipitation, quality of ground-water discharge, and by man-related activities such as agriculture and septic tank seepage. During and after channel modifications, stream quality also was affected by chemicals induced by excavation, clearing and snagging in the channel, and by increased ground-water discharge.

Water-quality data were not obtained in Creeping Swamp prior to channel modifications of the Chicod basin as part of this study; however, some samples were collected, just before the study period, as part of another project. They are included in this report for comparative purposes.

\section{Physical Characteristics}

The physical characteristics studied include suspended sediment, water temperature, dissolved oxygen, and $\mathrm{pH}$. These factors exert both direct and indirect influences on the chemical quality of the water and on the stream biota. Of these physical characteristics monitored, only suspended sediment differed significantly as a result of some channel modifications.

\section{Suspended sediment}

Suspended-sediment concentrations in streams vary primarily with streamflow, land use, soil type and cover, land slope, and rainfall intensity and duration. Although farming activities in the Chicod Creek basin create large areas of exposed land, the flat topography, sluggish streams, and permeable soils tend to minimize sediment transport. Prior to channel modifications, high sediment concentrations occurred in basin streams only during intense rains when storm runoff transported sediment from cultivated fields, road ditches, and other exposed areas (Watkins and Simmons, 1984). Excavation and clearing and snagging operations disturbed the streambed itself and contributed to elevated sediment concentrations in some reaches even during periods of base flow. As discussed in this section, however, the effects of channel modifications on sediment transport 
were variable among sites primarily because the extent and type of channel alteration varied from one site to another.

At Juniper Branch (site 1) sediment-transport curves (fig. 13) before and after excavation are markedly different compared to those during the period of excavation. Excavation was extensive in the Juniper Branch section of the basin and also was near the sampling site. As shown in figure 13, the transport curve defining characteristics during the excavation phase is considerably to the left of the curves defining conditions before and after excavation. For instance, at a flow of 100 $\mathrm{ft}^{3} / \mathrm{s}$, the sediment discharge was approximately 20 tons/d (tons per day) before and after excavation but was almost 50 tons/d during the excavation phase. The curve defining transport conditions after excavation is virtually coincidental with the curve before excavation (fig. 13), indicating that sediment-transport characteristics at site 1 had returned to approximately premodification conditions. Although the excavation phase in the Juniper Branch basin disturbed the streambed, created unstable banks, and resulted in easily erodible spoil piles, it is likely that natural deep pools, instream sediment traps, and rapid vegetation of spoil piles reduced the total sediment load during construction from the level it might have attained without such features.

Sediment-transport relations for Chicod Creek (site 2) (fig. 14) and Cow Swamp (site 3) (fig. 15) indicate less change in transport characteristics resulting from channel modifications than those that occurred at the other sites. Clearing and snagging operations, coupled with instream erosion control measures, resulted in no apparent increase in sediment transport. Several factors that might have reduced the availability of sediment during modifications of Chicod Creek and Cow Swamp relative to that which was available at Juniper Branch are: (1) the trapping of material by instream sediment traps and deep, natural pools, (2) the deposition of material derived from smaller, higher-gradient tributary streams as they flow into the more-sluggish, lower-gradient main channel streams, (3) the absence of spoil piles, (4) the undisturbed channel banks, and (5) the minimal modifications of the existing streambed within 2 to 3 miles upstream of the three sampling sites.

Sediment-transport relations for Chicod Creek (site 4) (fig. 16) indicate an increase in sediment transport. The transport curve for the period during modification is shifted up and to the left of the other curves. As with site 1 , site 4 is located relatively near reaches of 


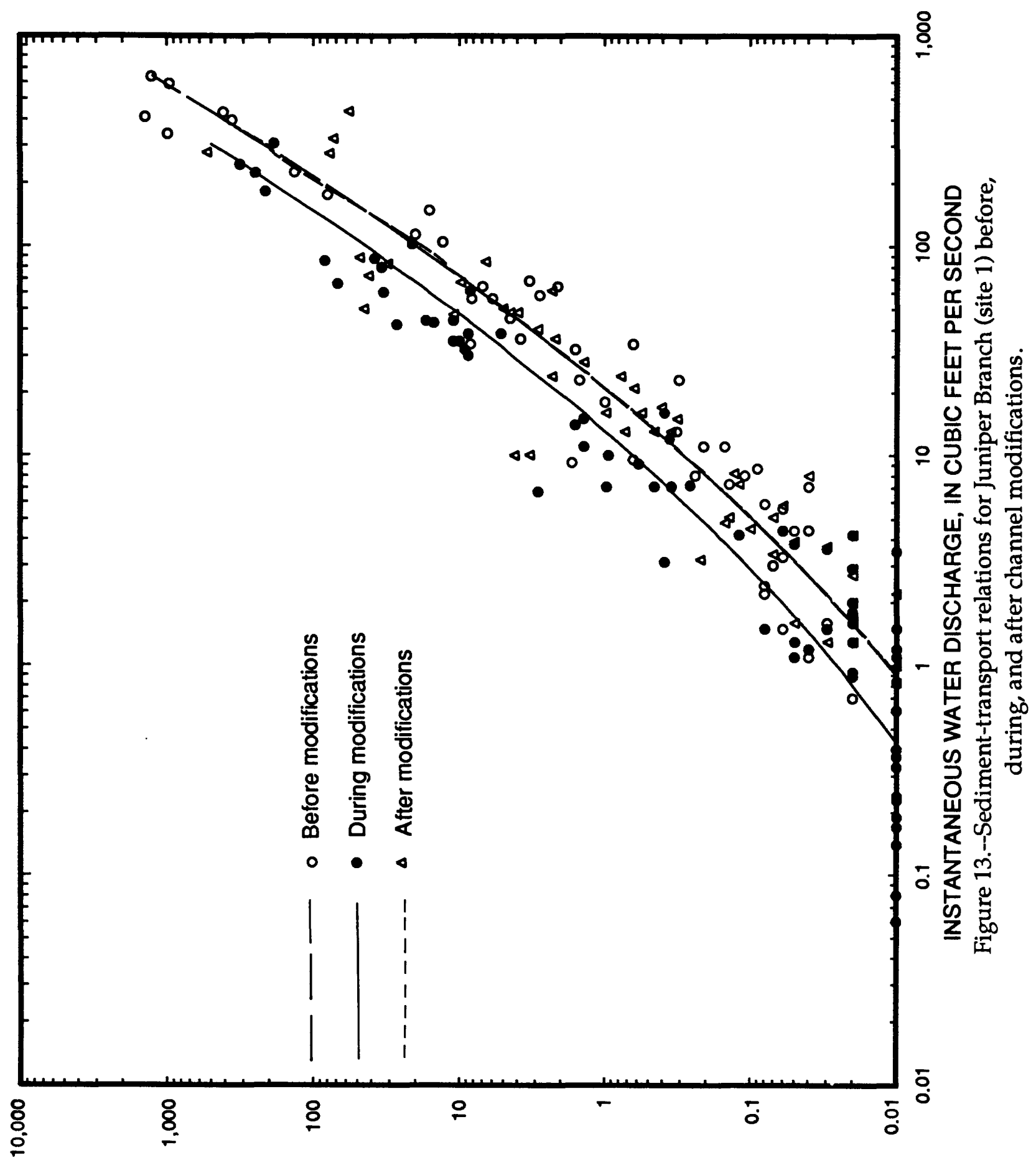

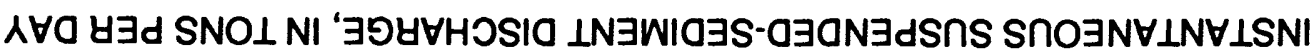




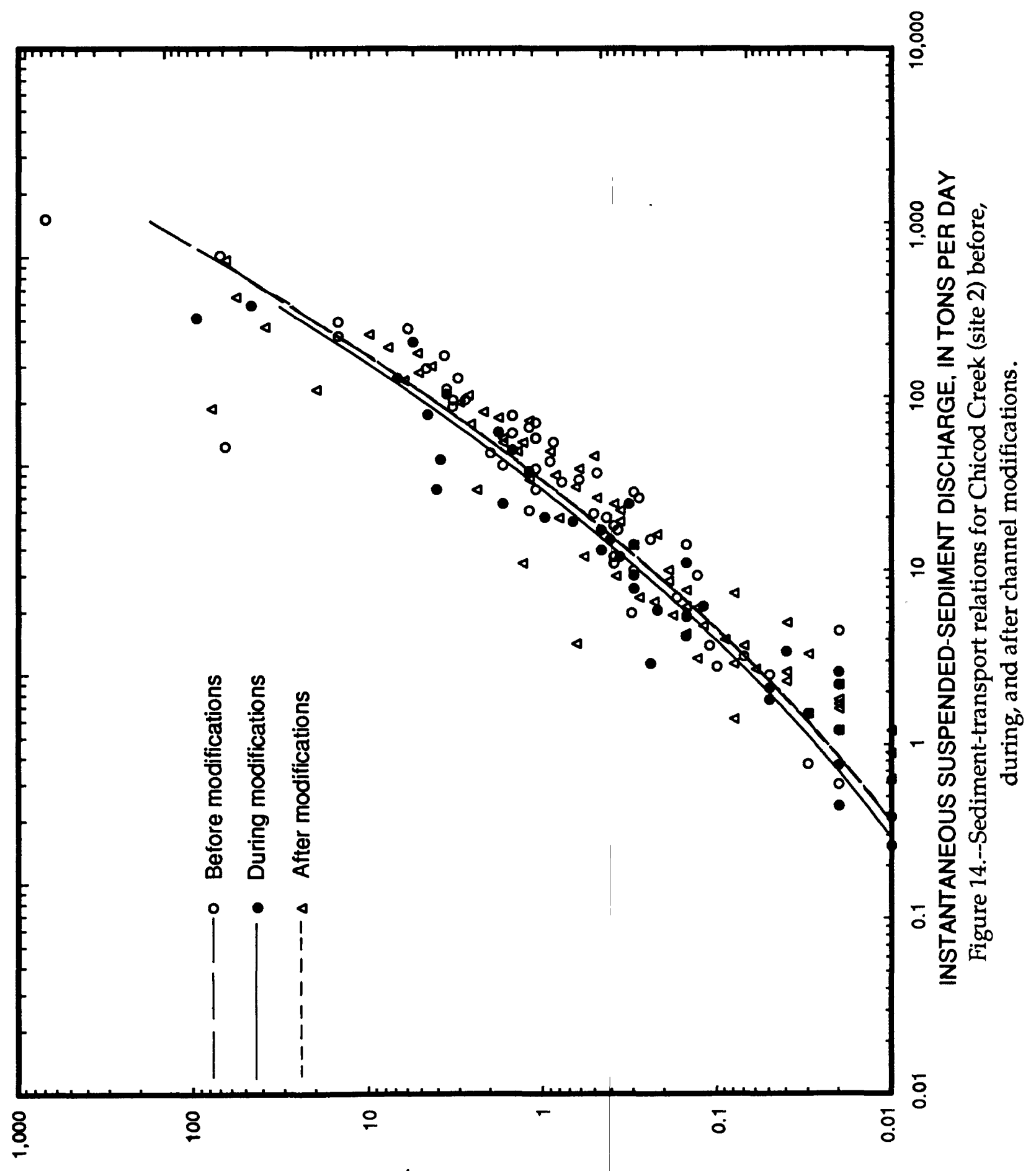

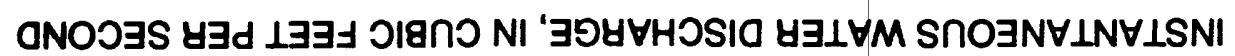




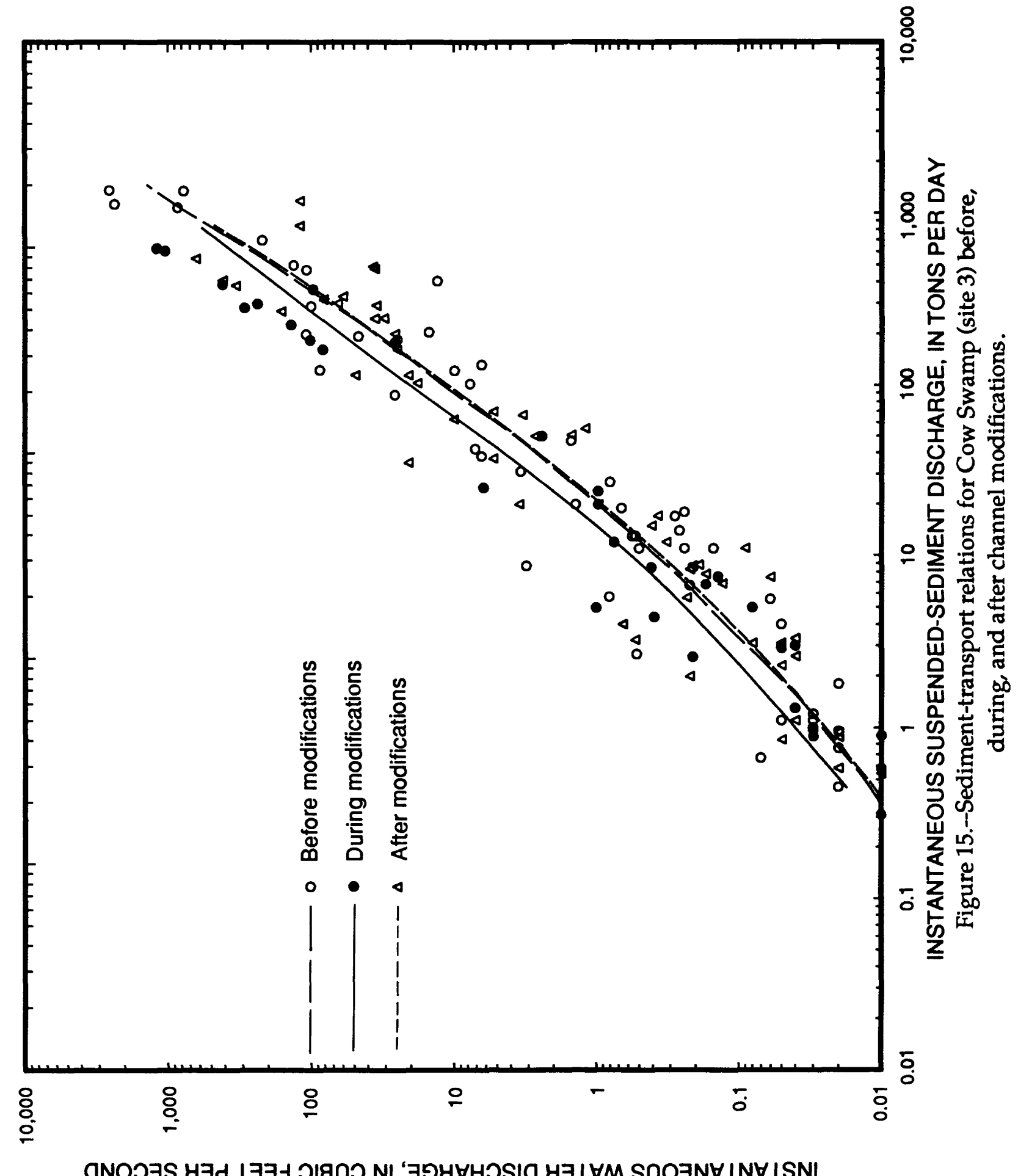

ONOOتS $\forall \exists d \perp \exists \exists \exists$ OIBกO NI ‘ $\exists$ 


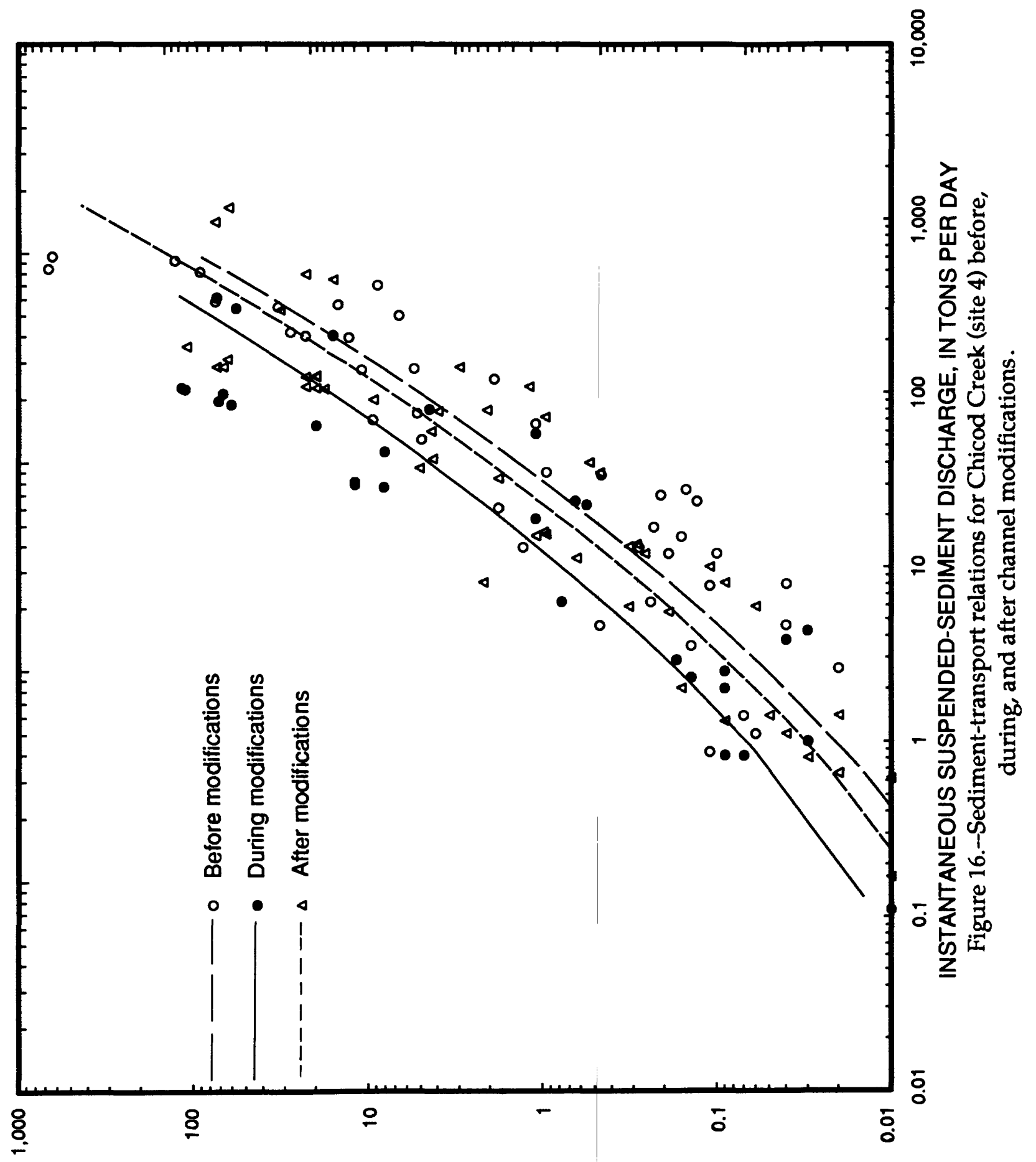

aNOJ 
channels that were excavated during modification but was not as exposed to the effects of upstream sediment traps as sites 2 and 3 were.

Suspended-sediment and streamflow data for the Juniper Branch (site 1) and Chicod Creek (site 2) stations are given in table 9. Although the daily mean water discharge at these sites was less during modifications than before, the daily mean sediment concentration was greater during modifications at both sites.

Table 9.--Suspended-sediment and streamflow data for Juniper Branch (site 1) and Chicod Creek (site 2) before, during, and after channel modifications

$\left[\mathrm{ft}^{3} / \mathrm{s}\right.$, cubic feet per second; mg/L, milligrams per liter; $t / \mathrm{mi}^{2}$, tons per square mile]

\begin{tabular}{|c|c|c|c|c|c|c|}
\hline \multirow{2}{*}{ Properties } & \multicolumn{3}{|c|}{$\begin{array}{l}\text { Juniper Branch, } \\
\text { site } 1\end{array}$} & \multicolumn{3}{|c|}{$\begin{array}{c}\text { Chicod Creek, } \\
\text { site } 2 \\
\end{array}$} \\
\hline & Before & During & After & Before & During & After \\
\hline $\begin{array}{l}\text { Mean daily water } \\
\text { discharge }\left(\mathrm{ft}^{3} / \mathrm{s}\right)\end{array}$ & 9.7 & 5.8 & 8.8 & 75 & 35 & 48 \\
\hline $\begin{array}{l}\text { Mean daily suspended- } \\
\text { sediment } \\
\text { concentration }(\mathrm{mg} / \mathrm{L})\end{array}$ & 26 & 70 & 31 & 52 & 77 & 39 \\
\hline $\begin{array}{l}\text { Annual suspended- } \\
\text { sediment yield } \\
\left(t / \mathrm{mi}^{2}\right)\end{array}$ & 33 & 53 & 36 & 86 & 59 & 47 \\
\hline $\begin{array}{l}\text { Ranges of } \\
\text { instantaneous } \\
\text { suspended-sediment } \\
\text { concentrations } \\
(\mathrm{mg} / \mathrm{L})\end{array}$ & $0-1,260$ & $0-482$ & $1-706$ & $0-662$ & $0-422$ & $1-725$ \\
\hline
\end{tabular}

Instantaneous suspended-sediment data for sites 1-4 (table 10) reflect conditions during selected short-term periods and extreme flow conditions and generally are not representative of the long-term mean and other statistical values characterizing specific study phases. They are included to show the effect of modification on sediment transport characteristics during selected high-flow periods (selected because streamflow was the result of storm runoff) and during selected low-flow periods (selected because rain had not occurred for at least 7 days prior to sampling). Samples collected during intermediate ranges of flow are not included. More complete statistical summaries of all sediment data collected before, during, and after modifications are shown in table 11. 
Table 10.--Summary statistics for selected physical characteristics and streamflow for selected base-flow and high-flow periods before, during, and after channel modifications in the Chicod Creek basin

[N, number of samples; $\mathrm{ft}^{3} / \mathrm{s}$, cubic feet per second; ${ }^{\circ} \mathrm{C}$, degrees Celsius; mg/L, milligrams per liter; $t / d$, tons per day]

\begin{tabular}{|c|c|c|c|c|c|c|c|c|c|c|c|c|c|}
\hline \multirow{2}{*}{ Characteristic } & \multirow{2}{*}{$\begin{array}{c}\text { Site } \\
\text { number } \\
\text { (fig. 1) }\end{array}$} & \multicolumn{4}{|c|}{ Before } & \multicolumn{4}{|c|}{ Durting } & \multicolumn{4}{|c|}{ After } \\
\hline & & 1) Mean & Median & Range & $\mathbf{N}$ & Mean & Median & Range & $\mathrm{N}$ & Mean & Median & Range & $\mathrm{N}$ \\
\hline \multicolumn{14}{|c|}{ Base flow } \\
\hline $\begin{array}{l}\text { Instantaneous } \\
\text { streamf low } \\
\left(\mathrm{ft}^{3} / \mathrm{s}\right)\end{array}$ & $\begin{array}{l}1 \\
2 \\
3 \\
4\end{array}$ & $\begin{array}{l}2.4 \\
7.2 \\
1.6 \\
4.6\end{array}$ & $\begin{array}{l}1.4 \\
2.4 \\
.62 \\
4.6\end{array}$ & $\begin{array}{c}0.13-7.3 \\
.01-23 \\
.25-6.7 \\
1.4-7.8\end{array}$ & $\begin{array}{l}8 \\
6 \\
6 \\
3\end{array}$ & $\begin{array}{l}2.8 \\
8.2 \\
3.9 \\
2.1\end{array}$ & $\begin{array}{l}2.9 \\
5.9 \\
.3 \\
2\end{array}$ & $\begin{array}{c}1.5-4.2 \\
1-20 \\
.31-8.5 \\
.11-4.3\end{array}$ & $\begin{array}{l}5 \\
6 \\
5 \\
4\end{array}$ & $\begin{array}{l}2.1 \\
2.1 \\
1.8 \\
.26\end{array}$ & $\begin{array}{r}1.8 \\
1.2 \\
1.4 \\
.1\end{array}$ & $\begin{array}{r}1-4.2 \\
.10-6.2 \\
.94-3.1 \\
.07-.62\end{array}$ & $\begin{array}{l}6 \\
9 \\
3 \\
3\end{array}$ \\
\hline $\begin{array}{l}\text { Temperature } \\
\left({ }^{\circ} \mathrm{C}\right)\end{array}$ & $\begin{array}{l}1 \\
2 \\
3 \\
4\end{array}$ & $\begin{array}{l}16 \\
16 \\
17 \\
16\end{array}$ & $\begin{array}{l}18 \\
18 \\
19 \\
18\end{array}$ & $\begin{array}{r}8-22 \\
8-22 \\
11-21 \\
9-21\end{array}$ & $\begin{array}{l}6 \\
6 \\
5 \\
3\end{array}$ & $\begin{array}{r}13 \\
14 \\
12 \\
9\end{array}$ & $\begin{array}{c}11 \\
15 \\
10 \\
8.2\end{array}$ & $\begin{array}{r}.5-25 \\
0-24 \\
0-25 \\
0-21\end{array}$ & $\begin{array}{l}5 \\
6 \\
5 \\
4\end{array}$ & $\begin{array}{l}17 \\
17 \\
14 \\
15\end{array}$ & $\begin{array}{l}17 \\
21 \\
14 \\
16\end{array}$ & $\begin{array}{l}9-26 \\
8-26 \\
8-20 \\
8-21\end{array}$ & $\begin{array}{l}4 \\
9 \\
3 \\
3\end{array}$ \\
\hline $\begin{array}{l}\text { Dissolved oxygen } \\
(\mathrm{mg} / \mathrm{L})\end{array}$ & $\begin{array}{l}1 \\
2 \\
3 \\
4\end{array}$ & $\begin{array}{l}5.3 \\
6.2 \\
3.1 \\
6.4\end{array}$ & $\begin{array}{l}5.6 \\
6.6 \\
3.5 \\
5.5\end{array}$ & $\begin{array}{l}2.7-7.5 \\
1.6-11 \\
.8-4.9 \\
3.6-10\end{array}$ & $\begin{array}{l}6 \\
5 \\
6 \\
3\end{array}$ & $\begin{array}{l}8.7 \\
7.4 \\
6 \\
6.4\end{array}$ & $\begin{array}{l}8.2 \\
6.3 \\
3.4 \\
6.1\end{array}$ & $\begin{array}{l}4.9-12 \\
3.6-13 \\
2.9-11 \\
2.8-10\end{array}$ & $\begin{array}{l}5 \\
5 \\
5 \\
4\end{array}$ & $\begin{array}{l}7.4 \\
5.2 \\
5.6 \\
5.4\end{array}$ & $\begin{array}{l}7.6 \\
5.3 \\
6.4 \\
4\end{array}$ & $\begin{array}{l}6.1-8.2 \\
2.4-7.8 \\
3.5-6.9 \\
3.7-8.5\end{array}$ & $\begin{array}{l}4 \\
9 \\
3 \\
3\end{array}$ \\
\hline $\begin{array}{l}\text { Suspended-sediment } \\
\text { concentration } \\
(\mathrm{mg} / \mathrm{L})\end{array}$ & $\begin{array}{l}1 \\
2 \\
3 \\
4\end{array}$ & $\begin{array}{l}7 \\
7.4 \\
14 \\
9\end{array}$ & $\begin{array}{l}7 \\
7 \\
9 \\
5\end{array}$ & $\begin{array}{l}3-12 \\
5-11 \\
7-37 \\
3-19\end{array}$ & $\begin{array}{l}7 \\
5 \\
5 \\
3\end{array}$ & $\begin{array}{l}3 \\
7.7 \\
12 \\
18\end{array}$ & $\begin{array}{r}3 \\
7 \\
12 \\
16\end{array}$ & $\begin{array}{l}2-5 \\
4-15 \\
5-18 \\
3-35\end{array}$ & $\begin{array}{l}4 \\
6 \\
5 \\
4\end{array}$ & $\begin{array}{c}3.2 \\
10 \\
6 \\
14\end{array}$ & $\begin{array}{l}3.5 \\
5 \\
6 \\
7\end{array}$ & $\begin{array}{l}2-4 \\
2-33 \\
6 \\
6-28\end{array}$ & $\begin{array}{l}6 \\
9 \\
2 \\
3\end{array}$ \\
\hline $\begin{array}{l}\text { Suspended-sediment } \\
\text { discharge } \\
(\mathrm{t} / \mathrm{d})\end{array}$ & $\begin{array}{l}1 \\
2 \\
3 \\
4\end{array}$ & $\begin{array}{l}.04 \\
.16 \\
.07 \\
.07\end{array}$ & $\begin{array}{l}.03 \\
.03 \\
.03 \\
.07\end{array}$ & $\begin{array}{c}0-.14 \\
0-.5 \\
.01-.22 \\
.04-.11\end{array}$ & $\begin{array}{l}7 \\
5 \\
5 \\
3\end{array}$ & $\begin{array}{l}.03 \\
.14 \\
.13 \\
.06\end{array}$ & $\begin{array}{l}.02 \\
.12 \\
.04 \\
.03\end{array}$ & $\begin{array}{l}.01-.05 \\
.02-.38 \\
.01-.41 \\
.01-.17\end{array}$ & $\begin{array}{l}4 \\
6 \\
5 \\
4\end{array}$ & $\begin{array}{l}.02 \\
.04 \\
.04 \\
0\end{array}$ & $\begin{array}{l}.02 \\
.08 \\
.04 \\
0\end{array}$ & $\begin{array}{r}0-.02 \\
0-.13 \\
.02-.05 \\
0-.01\end{array}$ & $\begin{array}{l}6 \\
9 \\
2 \\
3\end{array}$ \\
\hline $\mathrm{pH}$ & $\begin{array}{l}1 \\
2 \\
3 \\
4\end{array}$ & $\begin{array}{l}6.4 \\
6.4 \\
6.7 \\
5.4\end{array}$ & $\begin{array}{l}6.4 \\
6.5 \\
6.8 \\
5.7\end{array}$ & $\begin{array}{l}5.9-6.8 \\
5.7-6.8 \\
5.9-7 \\
4.7-5.9\end{array}$ & $\begin{array}{l}6 \\
6 \\
6 \\
3\end{array}$ & $\begin{array}{l}6.5 \\
6.4 \\
6.5 \\
6.3\end{array}$ & $\begin{array}{l}6.5 \\
6.4 \\
6.5 \\
6.4\end{array}$ & $\begin{array}{l}5.5-7.2 \\
5.2-7.2 \\
6.2-6.8 \\
5.6-6.8\end{array}$ & $\begin{array}{l}5 \\
6 \\
5 \\
4\end{array}$ & $\begin{array}{l}6.7 \\
6.5 \\
6.8 \\
6.3\end{array}$ & $\begin{array}{l}6.7 \\
6.5 \\
6.7 \\
6.3\end{array}$ & $\begin{array}{l}6.2-7.3 \\
6.2-7.1 \\
6.6-7.1 \\
6.2-6.3\end{array}$ & $\begin{array}{l}4 \\
9 \\
3 \\
3\end{array}$ \\
\hline \multicolumn{14}{|c|}{ High flow } \\
\hline $\begin{array}{l}\text { Instantaneous } \\
\text { streamflow } \\
\left(\mathrm{ft}^{3} / \mathrm{s}\right)\end{array}$ & $\begin{array}{ll}1 & \\
2 & 1 \\
3 & \\
4 & \end{array}$ & $\begin{array}{r}350 \\
1,240 \\
850 \\
441\end{array}$ & $\begin{array}{r}398 \\
1,320 \\
882 \\
492\end{array}$ & $\begin{array}{l}56-637 \\
545-2,020 \\
404-1,350 \\
211-606\end{array}$ & $\begin{array}{l}6 \\
7 \\
6 \\
7\end{array}$ & $\begin{array}{r}92 \\
687 \\
368 \\
178\end{array}$ & $\begin{array}{r}44 \\
668 \\
360 \\
159\end{array}$ & $\begin{array}{c}38-245 \\
438-1,010 \\
179-621 \\
31-350\end{array}$ & $\begin{array}{l}5 \\
8 \\
5 \\
6\end{array}$ & $\begin{array}{l}99.4 \\
557 \\
338 \\
289\end{array}$ & $\begin{array}{r}50 \\
380 \\
292 \\
140\end{array}$ & $\begin{array}{l}3.2-437 \\
4.6-2,080 \\
3.2-1,170 \\
.17-1,160\end{array}$ & $\begin{array}{l}17 \\
16 \\
17 \\
16\end{array}$ \\
\hline $\begin{array}{l}\text { Temperature } \\
\left({ }^{\circ} \mathrm{C}\right)\end{array}$ & $\begin{array}{l}1 \\
2 \\
3 \\
4\end{array}$ & $\begin{array}{l}15 \\
15 \\
13 \\
15\end{array}$ & $\begin{array}{l}14 \\
16 \\
12 \\
15\end{array}$ & $\begin{array}{l}7.5-21 \\
7.5-22 \\
7.5-21 \\
7.5-21\end{array}$ & $\begin{array}{l}6 \\
6 \\
5 \\
7\end{array}$ & $\begin{array}{l}17 \\
18 \\
17 \\
19\end{array}$ & $\begin{array}{l}20 \\
21 \\
20 \\
21\end{array}$ & $\begin{array}{r}6-21 \\
5-23 \\
4.5-22 \\
5-23\end{array}$ & $\begin{array}{l}4 \\
5 \\
5 \\
6\end{array}$ & $\begin{array}{l}17 \\
14 \\
16 \\
16\end{array}$ & $\begin{array}{l}21 \\
14 \\
20 \\
20\end{array}$ & $\begin{array}{r}7-24 \\
4.5-25 \\
8-24 \\
7-24\end{array}$ & $\begin{array}{r}8 \\
15 \\
9 \\
9\end{array}$ \\
\hline $\begin{array}{l}\text { Dissolved oxygen } \\
\text { (mg/L) }\end{array}$ & $\begin{array}{l}1 \\
2 \\
3 \\
4\end{array}$ & $\begin{array}{l}7.2 \\
6.9 \\
7.5 \\
6.2\end{array}$ & $\begin{array}{l}7.8 \\
5.4 \\
8.1 \\
6\end{array}$ & $\begin{array}{c}4.6-9.6 \\
4.6-10 \\
5-8 \\
3.6-9.5\end{array}$ & $\begin{array}{l}5 \\
5 \\
4 \\
6\end{array}$ & $\begin{array}{l}8.1 \\
8.2 \\
7.6 \\
7.1\end{array}$ & $\begin{array}{l}7.1 \\
6.7 \\
6.6 \\
5.8\end{array}$ & $\begin{array}{l}6.5-11 \\
5.9-12 \\
5.1-12 \\
5.3-11\end{array}$ & $\begin{array}{l}4 \\
3 \\
4 \\
4\end{array}$ & $\begin{array}{l}7.6 \\
7.5 \\
6.9 \\
6.5\end{array}$ & $\begin{array}{l}7.4 \\
6.8 \\
6 \\
6.2\end{array}$ & $\begin{array}{l}\quad 6-9.3 \\
3.7-12 \\
5.2-9 \\
3.6-9.3\end{array}$ & $\begin{array}{r}8 \\
14 \\
8 \\
8\end{array}$ \\
\hline $\begin{array}{l}\text { Suspended-sediment } \\
\text { concentration } \\
(\mathrm{mg} / \mathrm{L})\end{array}$ & $\begin{array}{l}1 \\
2 \\
3 \\
4\end{array}$ & $\begin{array}{l}516 \\
168 \\
334 \\
155\end{array}$ & $\begin{array}{r}352 \\
146 \\
207 \\
69\end{array}$ & $\begin{array}{l}12-1,260 \\
14-595 \\
12-776 \\
8-488\end{array}$ & $\begin{array}{l}9 \\
7 \\
6 \\
7\end{array}$ & $\begin{array}{l}194 \\
134 \\
313 \\
141\end{array}$ & $\begin{array}{r}142 \\
60 \\
295 \\
96\end{array}$ & $\begin{array}{l}85-482 \\
15-426 \\
54-716 \\
28-410\end{array}$ & $\begin{array}{l}5 \\
7 \\
5 \\
6\end{array}$ & $\begin{array}{c}65.5 \\
85 \\
109 \\
62\end{array}$ & $\begin{array}{l}48 \\
55 \\
60 \\
40\end{array}$ & $\begin{array}{r}4-218 \\
4-297 \\
28-381 \\
9-195\end{array}$ & $\begin{array}{l}19 \\
16 \\
16 \\
15\end{array}$ \\
\hline $\begin{array}{l}\text { Suspended-sediment } \\
\text { discharge } \\
(\mathrm{t} / \mathrm{d})\end{array}$ & $\begin{array}{ll}1 & \\
2 & \\
3 & 1 \\
4 & \end{array}$ & $\begin{array}{r}615 \\
813 \\
1,020 \\
225\end{array}$ & $\begin{array}{r}412 \\
426 \\
538 \\
92\end{array}$ & $\begin{array}{c}2.1-1,400 \\
31-2,940 \\
12-2,560 \\
7-676\end{array}$ & $\begin{array}{l}9 \\
6 \\
6 \\
7\end{array}$ & $\begin{array}{r}79 \\
215 \\
395 \\
49\end{array}$ & $\begin{array}{r}17 \\
74 \\
237 \\
38\end{array}$ & $\begin{array}{l}8.7-319 \\
26-810 \\
26-1,200 \\
12-117\end{array}$ & $\begin{array}{l}5 \\
7 \\
5 \\
6\end{array}$ & $\begin{array}{r}22 \\
160 \\
97 \\
34\end{array}$ & $\begin{array}{l}6.6 \\
99 \\
43 \\
23\end{array}$ & $\begin{array}{l}.15-78 \\
.05-330 \\
.53-417 \\
.01-75\end{array}$ & $\begin{array}{l}17 \\
16 \\
16 \\
15\end{array}$ \\
\hline $\mathrm{pH}$ & $\begin{array}{l}1 \\
2 \\
3 \\
4\end{array}$ & $\begin{array}{l}5.6 \\
5.8 \\
5.5 \\
5.3\end{array}$ & $\begin{array}{l}5.6 \\
5.8 \\
5.4 \\
5.5\end{array}$ & $\begin{array}{r}5-6.4 \\
5.4-6.4 \\
5.2-5.9 \\
4.4-6.3\end{array}$ & $\begin{array}{l}6 \\
7 \\
6 \\
7\end{array}$ & $\begin{array}{l}5.7 \\
6.2 \\
5.9 \\
5.6\end{array}$ & $\begin{array}{l}5.5 \\
6 \\
6.1 \\
5.6\end{array}$ & $\begin{array}{l}5.5-6.1 \\
5.9-6.8 \\
5.6-6.2 \\
5.4-5.8\end{array}$ & $\begin{array}{l}5 \\
6 \\
5 \\
6\end{array}$ & $\begin{array}{l}6.3 \\
6.2 \\
6.2 \\
5.8\end{array}$ & $\begin{array}{l}6.2 \\
6.1 \\
5.9 \\
5.8\end{array}$ & $\begin{array}{l}5.9-6.7 \\
5.4-6.8 \\
5.8-7 \\
5.1-6.7\end{array}$ & $\begin{array}{r}7 \\
12 \\
7 \\
7\end{array}$ \\
\hline
\end{tabular}




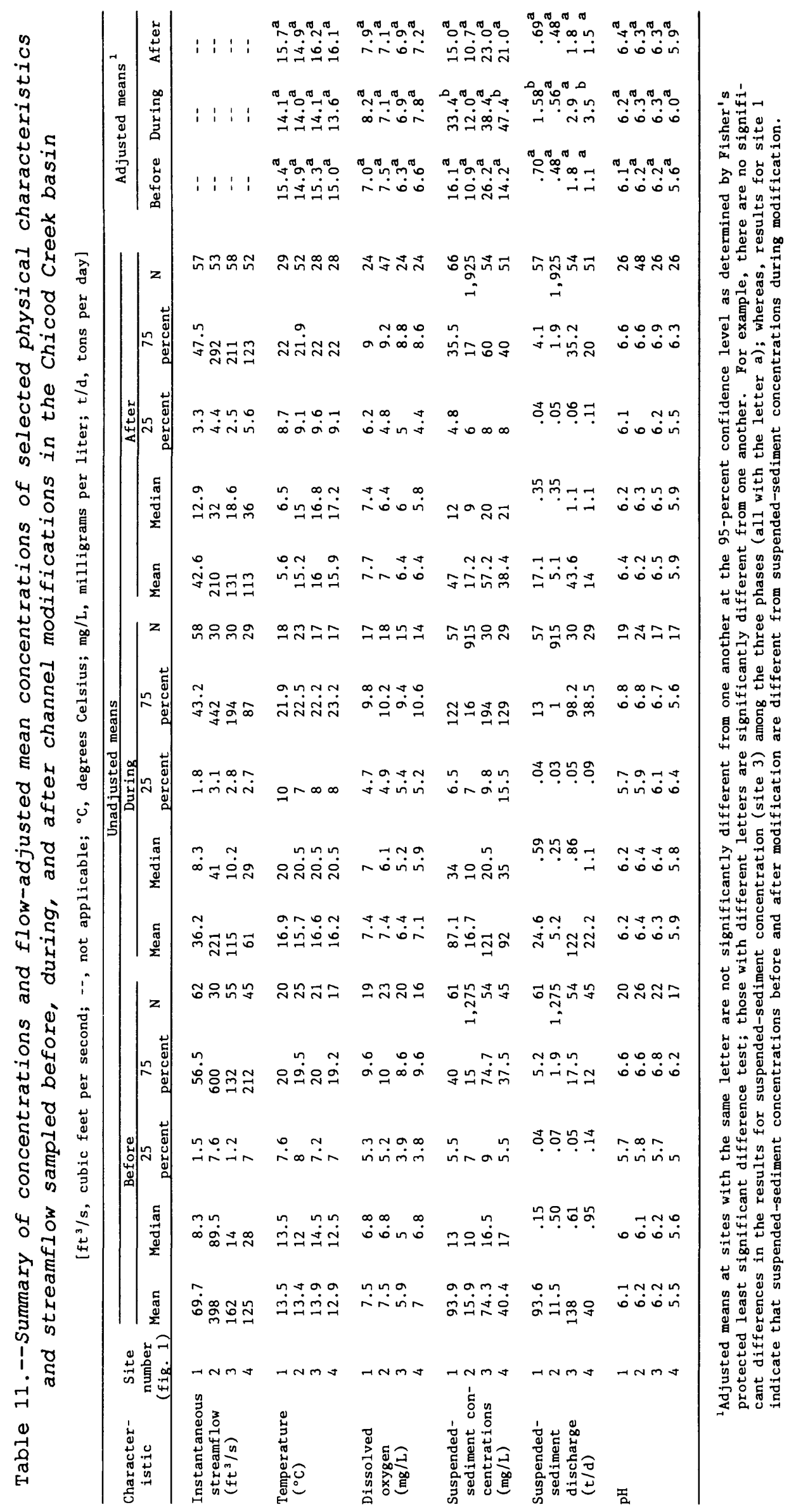


Sediment discharge increases with increasing flow, and more sediment will likely be transported during wet weather, high-flow conditions than during dry, base-flow conditions. To facilitate comparisons of the sediment-discharge and water-discharge data among the three phases of modification, analysis of covariance was used. The analysis indicates that sediment-discharge relations at Juniper Branch (site 1) and Chicod Creek (site 4) before and after channel modification were statistically different from relations during modification. After adjustment for differences in discharge (Steel and Torrie, 1980), the adjusted mean daily sediment discharge at Juniper Branch more than doubled during channel modification, increasing from 0.70 to 1.5 tons/d (table 11). After modification the flowadjusted mean daily sediment discharge declined to 0.69 ton $/ \mathrm{d}$. A somewhat similar pattern of change occurred at Chicod Creek (site 4) where flowadjusted mean daily sediment discharge was $1.0,3.5$, and 1.5 tons/d before, during, and after modifications, respectively. There were no statistically significant differences at Chicod Creek (site 2) and Cow Swamp (site 3) at the 95 -percent level.

Sediment yield is also a function of streamflow. To facilitate comparisons of sediment yields among the three phases of channel modification (before, during, and after) at Juniper Branch, streamflow-duration data for only the before-modification period were applied to sedimenttransport curves (fig. 13) for all three phases of modification. The flowduration sediment-transport curve method described by simmons (1988) was used for the computations. This procedure shows that, had the same runoff conditions occurred during each phase of the study, the effects of channel excavation alone would have increased suspended-sediment discharge at Juniper Branch from 330 tons/yr before modification to 1,100 tons/yr during modification, or an approximate increase of about 300 percent.

\section{Temperature}

The temperature of surface water is influenced by ambient air temperature, solar radiation, the temperature and volume of incoming groundwater, and vegetative cover. Removing the natural canopy of vegetation and exposing previously-shaded parts of the stream to direct solar radiation through channel-modification activities could increase stream temperatures. Increases in the amount of cooler ground water flowing into the stream after channel modifications might also tend to decrease stream temperatures in the summer months. 
Selected base-flow and high-flow periods were chosen from the hydrographs at Juniper Branch (site 1) and Chicod Creek (site 2) for the analysis of temperature data. Temperatures observed during base flows were preceded by at least 10 days of uninterrupted flow recession, and high-flow temperatures during high flows were observed on the rising stage at or just below the crest of the hydrograph. Means and ranges of temperatures observed during these selected periods in the Chicod Creek basin are presented in table 10; summaries of temperature data before, during, and after modifications are shown in table 11 . In general, mean temperatures ranged from 9 to $17^{\circ} \mathrm{C}$ during base flow and from 13 to $19^{\circ} \mathrm{C}$ during high flow (table 10).

Instantaneous stream temperature data for all channelized sites and daily stream temperature data for Chicod Creek (site 2) were compared to air temperature data collected by the National Oceanic and Atmospheric Administration (1987). Analyses of covariance of concurrent water and air temperatures were conducted. The results of these analyses indicate that no significant changes in mean or seasonal stream temperatures occurred during or after channel modifications. The adjusted mean water temperatures before, during, and after modifications are shown in table 11.

\section{Dissolved oxygen}

Dissolved-oxygen concentrations in stream water are related primarily to temperature; the biological processes of decomposition, oxidation, respiration and photosynthesis; and the reaeration capacity of the stream, which is a function of stream turbulence. These factors might be affected by channel modifications, which in turn could cause changes in dissolvedoxygen concentrations. Temporary changes in dissolved-oxygen concentration might also result from disturbance of anaerobic bottom sediment during modifications.

Dissolved-oxygen concentrations were recorded over a wide range of flow and temperature conditions throughout the study. Mean dissolved-oxygen concentrations ranged from a minimum of $5.9 \mathrm{mg} / \mathrm{L}$ at Cow Swamp (site 3 ) before modifications to a maximum of $7.7 \mathrm{mg} / \mathrm{L}$ at Juniper Branch after modifications (table 11). During summer and fall base-flow periods throughout the study, concentrations at all sampling sites frequently declined below the $5 \mathrm{mg} / \mathrm{L}$ value, which is needed to support a varied fish population (U.S. Environmental Protection Agency, 1986). Means and ranges of dissolved-oxygen concentrations for selected base flow and high-flow 
samples are presented in table 10. These values are not adjusted for temperature, flow, or time of day, and should not be used for determining trends. They serve only to represent conditions that existed during selected flow conditions.

Dissolved-oxygen concentrations before, during, and after channel modifications were tested using covariance analyses to determine the significance of any changes. As indicated in table 3 , the initial covariance model for dissolved oxygen was a relatively complex model because of the need to account for many influencing factors. However, the initial models were simplified during the analysis by eliminating statistically insignificant explanatory variables. Only water temperature and month of year were significant; time of day was not significant. The results revealed no statistically significant change in dissolved-oxygen concentration during the three phases of the study (table 11). Although velocity and turbulence may have increased in some streams, the increases have not resulted in statistically significant increases in dissolved-oxygen concentrations.

$\underline{\mathrm{pH}}$

The $\mathrm{pH}$ of water is a major factor influencing the relative concentrations of dissolved and particulate metals in stream water. Acidic conditions increase solubility and favor dissolved species of metals. The $\mathrm{pH}$ of natural waters generally is controlled by the reactions of dissolved carbon dioxide with the water and is buffered by bicarbonates. However, the presence of naturally-occurring organic acids, or a reducing environment resulting from oxygen depletion, can decrease the $\mathrm{pH}$.

The mean $\mathrm{pH}$ of base-flow and high-flow waters tended to increase after channel modifications (table 10). For example, during base flow at site 4 the mean $\mathrm{pH}$ increased from 5.4 before channel modifications to 6.3 after modifications (table 10). However, using analysis of covariance (Steel and Torrie, 1980), no statistically significant changes in $\mathrm{pH}$ were apparent at any of the sites at the 95-percent level (table 11).

\section{Chemical Characteristics}

The chemical characteristics described in this section are major dissolved constituents, nutrients, trace metals, and pesticides. The major dissolved ions are calcium, magnesium, sodium, potassium, bicarbonate, 
sulfate, chloride, fluoride, silica and dissolved solids. The nutrients consist of several species of nitrogen and phosphorus, and the trace metals are copper, iron, lead, mercury, and zinc. Water and bottom sediments were analyzed for the pesticides chlordane, DDD, DDE, DDT, diazinon', dieldrin, endrin and heptachlor, and for polychlorinated biphenyls (PCB). Changes in these chemical characteristics in the Chicod Creek basin during and after channel modifications varied with flow conditions, the extent of channel modifications, prevailing ground-water chemical characteristics, and changes in agricultural practices and livestock operations.

Flow conditions commonly influence chemical quality in a stream, and maximum and minimum values of various constituents generally occur during extreme discharge events. To properly evaluate water-quality conditions before, during, and after channel modification, samples collected during similar flow conditions need to be compared to minimize the bias caused by large variations in flow. Thus, data collected during extended dry periods were selected as representative of base-flow periods and data collected during the highest flows were selected as representative of storm runoff.

\section{Major dissolved constituents}

Concentrations of the major dissolved constituents are usually at maximum levels during base-flow periods and tend to decrease with increased streamflow. Concentrations of these dissolved constituents generally are lower in streamflow during high-flow than during base flow because storm runoff tends to dilute many of the constituents contributed by ground water. This is shown in table 12, where major dissolved constituents were almost always in greater concentrations during base-flow periods during each of the modification phases.

A second, though less pronounced trend in concentration is also indicated from comparisons of concentrations among the three phases of modification within the base- and high-flow categories (table 12). Concentrations of most constituents are greater during and after channel modification than before. A similar trend of increasing concentration is indicated in table 13 . The median bicarbonate concentration at site 2 , for example, increased from $16 \mathrm{mg} / \mathrm{L}$ before to $26 \mathrm{mg} / \mathrm{L}$ during modification, and then increased further to $30 \mathrm{mg} / \mathrm{L}$ after modification.

The use of brand names in this report is for identification purposes only and does not constitute endorsement by the U.S. Geological Survey. 
Table 12.--Summary statistics for concentrations of major dissolved constituents and after channel modifications in the Chicod Creek basin (sites 1, 2,

Creeping Swamp

[mg/L, milligrams per liter; $N$, number of

\begin{tabular}{|c|c|c|c|c|c|c|c|c|c|c|c|c|c|}
\hline \multirow{2}{*}{$\begin{array}{c}\text { Constituent } \\
(\mathrm{mg} / \mathrm{L})\end{array}$} & \multirow{2}{*}{$\begin{array}{c}\text { Site } \\
\text { number } \\
\text { (fig. 1) }\end{array}$} & \multicolumn{4}{|c|}{ Before } & \multicolumn{4}{|c|}{ During } & \multicolumn{4}{|c|}{ After } \\
\hline & & Mean & Median & Range & $\mathrm{N}$ & Mean & Median & Range & $\mathbf{N}$ & Mean & Median & Range & $\mathrm{N}$ \\
\hline \multicolumn{14}{|c|}{ Base flow } \\
\hline Calcium & $\begin{array}{l}1 \\
2 \\
3 \\
4 \\
5\end{array}$ & $\begin{array}{c}18 \\
13 \\
24 \\
9.7 \\
--\end{array}$ & $\begin{array}{c}17 \\
13 \\
24 \\
4.4 \\
--\end{array}$ & $\begin{array}{r}11-29 \\
7-18 \\
12-41 \\
2.7-22 \\
--\end{array}$ & $\begin{array}{r}6 \\
6 \\
6 \\
3 \\
--\end{array}$ & $\begin{array}{c}20 \\
16 \\
23 \\
4.9 \\
--\end{array}$ & $\begin{array}{c}18 \\
12 \\
25 \\
4.9 \\
--\end{array}$ & $\begin{array}{c}14-25 \\
9.1-27 \\
17-28 \\
3.4-6.4 \\
--\end{array}$ & $\begin{array}{r}5 \\
6 \\
5 \\
4 \\
--\end{array}$ & $\begin{array}{l}20 \\
24 \\
34 \\
7.2 \\
4.8\end{array}$ & $\begin{array}{l}19.5 \\
24 \\
33 \\
7.2 \\
5.1\end{array}$ & $\begin{array}{c}18-21 \\
15-32 \\
32-37 \\
6.1-8.5 \\
3.6-5.7\end{array}$ & $\begin{array}{l}4 \\
9 \\
3 \\
3 \\
3\end{array}$ \\
\hline Magnesium & $\begin{array}{l}1 \\
2 \\
3 \\
4 \\
5\end{array}$ & $\begin{array}{l}2.6 \\
2.2 \\
3.4 \\
2.9 \\
. .\end{array}$ & $\begin{array}{l}2.3 \\
2.1 \\
2.8 \\
1.3 \\
-.-\end{array}$ & $\begin{array}{c}2.3-3.3 \\
1.6-2.8 \\
2.2-6.5 \\
.9-6.6 \\
--\end{array}$ & $\begin{array}{r}6 \\
6 \\
6 \\
3 \\
--\end{array}$ & $\begin{array}{l}2.6 \\
2.4 \\
2.7 \\
1.7 \\
-.-\end{array}$ & $\begin{array}{l}2.6 \\
2.1 \\
2.5 \\
1.6 \\
--\end{array}$ & $\begin{array}{c}2.3-2.9 \\
1.3-3.1 \\
1.7-3.7 \\
1.2-2.3 \\
--\end{array}$ & $\begin{array}{r}5 \\
6 \\
5 \\
4 \\
--\end{array}$ & $\begin{array}{l}2.5 \\
2.9 \\
3 \\
2.3 \\
1.3\end{array}$ & $\begin{array}{l}2.5 \\
2.9 \\
3 \\
2.1 \\
1.4\end{array}$ & $\begin{array}{l}2.2-2.7 \\
2.4-3.6 \\
2.8-3.1 \\
1.9-3 \\
1.1-1.5\end{array}$ & $\begin{array}{l}4 \\
9 \\
3 \\
3 \\
3\end{array}$ \\
\hline Sodium & $\begin{array}{l}1 \\
2 \\
3 \\
4 \\
5\end{array}$ & $\begin{array}{l}7.1 \\
6.7 \\
8.4 \\
7.1 \\
. .\end{array}$ & $\begin{array}{l}7 \\
6.7 \\
7.6 \\
5.4 \\
---\end{array}$ & $\begin{array}{l}6.4-8 \\
4.6-9.1 \\
6.5-12 \\
4.8-11 \\
\quad--\end{array}$ & $\begin{array}{r}6 \\
6 \\
6 \\
3 \\
--\end{array}$ & $\begin{array}{l}6.6 \\
7.1 \\
8.6 \\
5.7 \\
--\end{array}$ & $\begin{array}{l}6.2 \\
6.8 \\
8.3 \\
6 \\
--\end{array}$ & $\begin{array}{l}5.9-7.4 \\
5.3-8.7 \\
6.6-11 \\
4.3-6.5 \\
\quad-.\end{array}$ & $\begin{array}{r}5 \\
6 \\
5 \\
4 \\
--\end{array}$ & $\begin{array}{c}6.3 \\
9.3 \\
10 \\
9 \\
4.8\end{array}$ & $\begin{array}{l}6.3 \\
8.1 \\
9.8 \\
8.1 \\
4.8\end{array}$ & $\begin{array}{l}5.6-6.9 \\
6.3-15 \\
8.2-11 \\
8-11 \\
4.5-5\end{array}$ & $\begin{array}{l}4 \\
9 \\
3 \\
3 \\
3\end{array}$ \\
\hline Potassium & $\begin{array}{l}1 \\
2 \\
3 \\
4 \\
5\end{array}$ & $\begin{array}{l}3.7 \\
4.2 \\
7.8 \\
2.8 \\
-.\end{array}$ & $\begin{array}{l}3.2 \\
4 \\
5.8 \\
2.3 \\
--.\end{array}$ & $\begin{array}{l}2.4-7.2 \\
2.1-7.2 \\
3.2-20 \\
1.3-4.8 \\
--\end{array}$ & $\begin{array}{r}6 \\
6 \\
6 \\
3 \\
--\end{array}$ & $\begin{array}{l}3.1 \\
4.7 \\
7.5 \\
3.2 \\
-.-\end{array}$ & $\begin{array}{l}3.1 \\
4.6 \\
4.8 \\
2.8 \\
-.\end{array}$ & $\begin{array}{l}2.3-4 \\
3.6-7.1 \\
3.3-17 \\
2.1-5 \\
\quad--\end{array}$ & $\begin{array}{r}5 \\
6 \\
5 \\
4 \\
--\end{array}$ & $\begin{array}{l}2.7 \\
6.9 \\
6 \\
7.6 \\
2.1\end{array}$ & $\begin{array}{l}2.8 \\
7.2 \\
6 \\
6 \\
2.1\end{array}$ & $\begin{array}{l}1.5-3.6 \\
3.1-11 \\
3.1-8.8 \\
5.9-11 \\
1.5-2.6\end{array}$ & $\begin{array}{l}4 \\
9 \\
3 \\
3 \\
3\end{array}$ \\
\hline Bicarbonate & $\begin{array}{l}1 \\
2 \\
3 \\
4 \\
5\end{array}$ & $\begin{array}{c}34 \\
32 \\
76 \\
6.7 \\
--\end{array}$ & $\begin{array}{r}31 \\
31 \\
73 \\
5 \\
--\end{array}$ & $\begin{array}{c}20-57 \\
15-58 \\
28-140 \\
3-12 \\
--\end{array}$ & $\begin{array}{r}6 \\
6 \\
6 \\
3 \\
--\end{array}$ & $\begin{array}{l}42 \\
52 \\
95 \\
13 \\
--\end{array}$ & $\begin{array}{l}42 \\
41 \\
82 \\
15 \\
--\end{array}$ & $\begin{array}{l}32-53 \\
26-94 \\
50-168 \\
9-28 \\
--\end{array}$ & $\begin{array}{r}5 \\
5 \\
4 \\
3 \\
--\end{array}$ & $\begin{array}{r}44 \\
73 \\
109 \\
56 \\
14\end{array}$ & $\begin{array}{r}45 \\
68 \\
110 \\
42 \\
15\end{array}$ & $\begin{array}{l}38-48 \\
52-104 \\
89-128 \\
38-87 \\
8-20\end{array}$ & $\begin{array}{l}4 \\
9 \\
3 \\
3 \\
3\end{array}$ \\
\hline Sulfate & $\begin{array}{l}1 \\
2 \\
3 \\
4 \\
5\end{array}$ & $\begin{array}{l}26 \\
11 \\
11 \\
27 \\
--\end{array}$ & $\begin{array}{l}15 \\
8.3 \\
8.2 \\
6.4 \\
-.-\end{array}$ & $\begin{array}{c}13-61 \\
6.7-22 \\
2.9-22 \\
4.3-71 \\
--\end{array}$ & $\begin{array}{r}6 \\
6 \\
6 \\
3 \\
--\end{array}$ & $\begin{array}{l}24 \\
14 \\
19 \\
7.3 \\
--\end{array}$ & $\begin{array}{l}26 \\
12 \\
16 \\
7.1 \\
--\end{array}$ & $\begin{array}{r}13-35 \\
5.9-22 \\
6.5-31 \\
4.1-11 \\
--\end{array}$ & $\begin{array}{r}5 \\
6 \\
5 \\
4 \\
--\end{array}$ & $\begin{array}{c}20 \\
17 \\
23 \\
14 \\
5.6\end{array}$ & $\begin{array}{l}19.5 \\
18 \\
24 \\
9 \\
4.7\end{array}$ & $\begin{array}{r}18-25 \\
11-22 \\
21-24 \\
2.7-29 \\
1.2-11\end{array}$ & $\begin{array}{l}4 \\
9 \\
3 \\
3 \\
3\end{array}$ \\
\hline Chloride & $\begin{array}{l}1 \\
2 \\
3 \\
4 \\
5\end{array}$ & $\begin{array}{c}12 \\
11 \\
13 \\
9.4 \\
--\end{array}$ & $\begin{array}{r}12 \\
12 \\
12 \\
9 \\
--\end{array}$ & $\begin{array}{l}11-15 \\
7.8-14 \\
9.4-19 \\
6-3.13 \\
--\end{array}$ & $\begin{array}{r}6 \\
6 \\
6 \\
3 \\
--\end{array}$ & $\begin{array}{l}12 \\
12 \\
14 \\
11 \\
\ldots\end{array}$ & $\begin{array}{l}11 \\
12 \\
15 \\
11 \\
--\end{array}$ & $\begin{array}{r}11-14 \\
8.4-14 \\
13-16 \\
8-13 \\
--\end{array}$ & $\begin{array}{r}5 \\
6 \\
5 \\
3 \\
--\end{array}$ & $\begin{array}{l}11 \\
14 \\
14 \\
16 \\
10\end{array}$ & $\begin{array}{c}10 \\
15 \\
14 \\
14 \\
9.5\end{array}$ & $\begin{array}{r}9.8-13 \\
8.5-18 \\
13-16 \\
13-20 \\
9.2-12\end{array}$ & $\begin{array}{l}4 \\
9 \\
3 \\
3 \\
3\end{array}$ \\
\hline Fluoride & $\begin{array}{l}1 \\
2 \\
3 \\
4 \\
5\end{array}$ & $\begin{array}{l}.2 \\
.2 \\
.2 \\
.2 \\
-.\end{array}$ & $\begin{array}{l}.2 \\
.1 \\
.1 \\
.2 \\
-.-\end{array}$ & $\begin{array}{l}.1-.4 \\
.1-.8 \\
.1-.5 \\
.1-.3 \\
--\end{array}$ & $\begin{array}{r}6 \\
6 \\
6 \\
3 \\
--\end{array}$ & $\begin{array}{r}.2 \\
.1 \\
.2 \\
<.1 \\
. .\end{array}$ & $\begin{array}{l}.2 \\
.1 \\
.2 \\
.1 \\
-.\end{array}$ & $\begin{array}{c}.1-.2 \\
.1-.2 \\
.2 \\
<.1-.1 \\
.-\end{array}$ & $\begin{array}{r}5 \\
6 \\
5 \\
4 \\
--\end{array}$ & $\begin{array}{l}.1 \\
.2 \\
.2 \\
.1 \\
.1\end{array}$ & $\begin{array}{l}.1 \\
.2 \\
.2 \\
.1 \\
.1\end{array}$ & $\begin{array}{l}.1-.2 \\
.1-.2 \\
.2-.2 \\
.1-.1 \\
.1-.1\end{array}$ & $\begin{array}{l}4 \\
9 \\
3 \\
3 \\
3\end{array}$ \\
\hline Silica & $\begin{array}{l}1 \\
2 \\
3 \\
4 \\
5\end{array}$ & $\begin{array}{c}10 \\
7.1 \\
11 \\
8.9 \\
--\end{array}$ & $\begin{array}{l}10 \\
8.2 \\
11 \\
11 \\
--\end{array}$ & $\begin{array}{c}5.8-14 \\
2.3-11 \\
8-13 \\
2.8-13 \\
--\end{array}$ & $\begin{array}{r}6 \\
6 \\
6 \\
3 \\
--\end{array}$ & $\begin{array}{l}10 \\
9 \\
9.3 \\
9 \\
-.\end{array}$ & $\begin{array}{l}9.5 \\
8.5 \\
9.1 \\
8.6 \\
--\end{array}$ & $\begin{array}{c}8.9-12 \\
7.9-11 \\
6.8-12 \\
8-11 \\
--\end{array}$ & $\begin{array}{r}5 \\
6 \\
5 \\
4 \\
--\end{array}$ & $\begin{array}{c}7.8 \\
6.9 \\
10 \\
6.7 \\
6.8\end{array}$ & $\begin{array}{c}7.8 \\
6.8 \\
12 \\
6.6 \\
5.1\end{array}$ & $\begin{array}{l}5.7-10 \\
3.5-9.8 \\
6.1-12 \\
6.1-7.4 \\
2.4-13\end{array}$ & $\begin{array}{l}4 \\
9 \\
3 \\
3 \\
3\end{array}$ \\
\hline Dissolved solids & $\begin{array}{l}1 \\
2 \\
3 \\
4 \\
5\end{array}$ & $\begin{array}{r}111 \\
91 \\
152 \\
100 \\
-.\end{array}$ & $\begin{array}{r}95 \\
95 \\
126 \\
94 \\
--\end{array}$ & $\begin{array}{l}84-166 \\
67-110 \\
93-293 \\
50-158 \\
--\end{array}$ & $\begin{array}{r}6 \\
6 \\
6 \\
3 \\
--\end{array}$ & $\begin{array}{r}122 \\
104 \\
142 \\
78 \\
--\end{array}$ & $\begin{array}{c}130 \\
99 \\
150 \\
80.5 \\
--\end{array}$ & $\begin{array}{c}100-131 \\
82-130 \\
109-159 \\
62-84 \\
--\end{array}$ & $\begin{array}{r}5 \\
5 \\
4 \\
4 \\
--\end{array}$ & $\begin{array}{r}111 \\
145 \\
166 \\
114 \\
62\end{array}$ & $\begin{array}{r}112 \\
147 \\
166 \\
117 \\
64\end{array}$ & $\begin{array}{r}99-123 \\
121-186 \\
139-192 \\
99-125 \\
34-89\end{array}$ & $\begin{array}{l}4 \\
9 \\
3 \\
3 \\
3\end{array}$ \\
\hline
\end{tabular}


during selected base-flow and high-flow periods before, during, 3 , and 4) and for concurrent periods in the unmodified basin (site 5)

samples; --, insufficient data; <, less than]

\begin{tabular}{|c|c|c|c|c|c|c|c|c|c|c|c|}
\hline \multicolumn{4}{|c|}{ Before } & \multicolumn{4}{|c|}{ During } & \multicolumn{4}{|c|}{ After } \\
\hline Mean & Median & Range & $\mathbf{N}$ & Mean & Median & Range & $\mathbf{N}$ & Mean & Median & Range & $\mathbf{N}$ \\
\hline \multicolumn{12}{|c|}{ High flow } \\
\hline $\begin{array}{l}7 \\
5 \\
4.2 \\
2.8 \\
--\end{array}$ & $\begin{array}{l}4.4 \\
5.1 \\
4.3 \\
2.7 \\
--\end{array}$ & $\begin{array}{l}3.3-14 \\
3.3-7.6 \\
3.2-5 \\
2.2-4.4 \\
=-\end{array}$ & $\begin{array}{r}5 \\
5 \\
4 \\
7 \\
--\end{array}$ & $\begin{array}{l}9.6 \\
5.2 \\
5.5 \\
3.4 \\
3.9\end{array}$ & $\begin{array}{l}9.9 \\
5.1 \\
5.1 \\
3.4 \\
--\end{array}$ & $\begin{array}{c}6.9-13 \\
4.1-6.5 \\
4.4-6.7 \\
2.7-4.1 \\
3.9\end{array}$ & $\begin{array}{l}5 \\
8 \\
5 \\
6 \\
1\end{array}$ & $\begin{array}{r}11.9 \\
8.9 \\
9.5 \\
4.1 \\
4.9\end{array}$ & $\begin{array}{l}11 \\
7.9 \\
6.4 \\
4 \\
5.8\end{array}$ & $\begin{array}{l}5.9-20 \\
4.4-26 \\
3.8-25 \\
2.8-5.2 \\
2.6-7.8\end{array}$ & $\begin{array}{r}9 \\
16 \\
8 \\
8 \\
7\end{array}$ \\
\hline $\begin{array}{l}1.4 \\
1 \\
.9 \\
.9\end{array}$ & $\begin{array}{r}1.2 \\
.9 \\
.9 \\
.8 \\
-.\end{array}$ & $\begin{array}{l}.9-2.4 \\
.8-1.3 \\
.7-1.1 \\
.7-1.6 \\
--\end{array}$ & $\begin{array}{r}5 \\
5 \\
4 \\
7 \\
--\end{array}$ & $\begin{array}{r}2.2 \\
1.1 \\
1.2 \\
1.2 \\
.9\end{array}$ & $\begin{array}{l}2.4 \\
1.1 \\
1.1 \\
1.2 \\
--\end{array}$ & $\begin{array}{r}1.6-2.6 \\
.9-1.4 \\
1-1.5 \\
1.1-1.5 \\
.9\end{array}$ & $\begin{array}{l}5 \\
8 \\
5 \\
6 \\
1\end{array}$ & $\begin{array}{l}2.5 \\
1.8 \\
1.7 \\
1.4 \\
1.4\end{array}$ & $\begin{array}{l}2.4 \\
1.7 \\
1.2 \\
1.4 \\
1.6\end{array}$ & $\begin{array}{r}1.4-4.4 \\
1-4.3 \\
.8-3.2 \\
.9-2.1 \\
.6-2.2\end{array}$ & $\begin{array}{r}9 \\
16 \\
8 \\
8 \\
7\end{array}$ \\
\hline $\begin{array}{l}3.4 \\
2.6 \\
2.2 \\
2.5 \\
--\end{array}$ & $\begin{array}{l}2.7 \\
2.4 \\
2 \\
2.3 \\
-.\end{array}$ & $\begin{array}{l}2-5.7 \\
1.8-4 \\
1.7-3.3 \\
2.2-3.5 \\
\quad--\end{array}$ & $\begin{array}{r}5 \\
5 \\
4 \\
7 \\
--\end{array}$ & $\begin{array}{l}4.7 \\
2.9 \\
2.8 \\
3.2 \\
3.1\end{array}$ & $\begin{array}{l}5.1 \\
2.8 \\
2.7 \\
2.9 \\
--\end{array}$ & $\begin{array}{c}3.7-5.4 \\
2.1-4.2 \\
2.2-3.8 \\
2.5-4.3 \\
\quad 3.1\end{array}$ & $\begin{array}{l}5 \\
8 \\
5 \\
6 \\
1\end{array}$ & $\begin{array}{l}5.2 \\
4.6 \\
4.2 \\
3.2 \\
4.4\end{array}$ & $\begin{array}{l}5.2 \\
3.8 \\
2.8 \\
3 \\
4\end{array}$ & $\begin{array}{l}2.3-8 \\
1.8-14 \\
1.4-11 \\
1.5-4.9 \\
1.5-8.2\end{array}$ & $\begin{array}{r}9 \\
16 \\
8 \\
8 \\
7\end{array}$ \\
\hline $\begin{array}{l}2.8 \\
3.3 \\
2.7 \\
2.3 \\
--\end{array}$ & $\begin{array}{l}3 \\
3 \\
2.5 \\
2.3 \\
--\end{array}$ & $\begin{array}{r}2.2-3.3 \\
2.2-5.2 \\
2-3.9 \\
1.5-3 \\
--\end{array}$ & $\begin{array}{r}5 \\
5 \\
4 \\
7 \\
--\end{array}$ & $\begin{array}{l}3.5 \\
4.5 \\
3.6 \\
2.6 \\
2\end{array}$ & $\begin{array}{l}4 \\
3.8 \\
3.4 \\
2.8 \\
--\end{array}$ & $\begin{array}{c}2.5-4.4 \\
2.5-6.6 \\
2.7-4.5 \\
1.5-3 \\
2\end{array}$ & $\begin{array}{l}5 \\
8 \\
5 \\
6 \\
1\end{array}$ & $\begin{array}{l}4.3 \\
6.1 \\
5.3 \\
3 \\
2\end{array}$ & $\begin{array}{l}4.5 \\
5.4 \\
3.8 \\
3 \\
2\end{array}$ & $\begin{array}{l}2.9-6.7 \\
2.6-18 \\
3.3-11 \\
1.9-3.8 \\
1.3-3.3\end{array}$ & $\begin{array}{r}9 \\
16 \\
8 \\
8 \\
7\end{array}$ \\
\hline $\begin{array}{l}6 \\
8 \\
6.2 \\
4.7 \\
--\end{array}$ & $\begin{array}{l}7 \\
8 \\
6.5 \\
5 \\
--\end{array}$ & $\begin{array}{l}4-8 \\
6-9 \\
4-8 \\
3-9 \\
--\end{array}$ & $\begin{array}{r}5 \\
5 \\
4 \\
7 \\
--\end{array}$ & $\begin{array}{l}7.6 \\
14 \\
11 \\
5.8 \\
6\end{array}$ & $\begin{array}{l}8 \\
12.5 \\
11 \\
5.5 \\
--\end{array}$ & $\begin{array}{c}4-10 \\
10-24 \\
8-13 \\
4-9 \\
6\end{array}$ & $\begin{array}{l}5 \\
6 \\
5 \\
6 \\
1\end{array}$ & $\begin{array}{l}18.7 \\
22 \\
28 \\
11 \\
5.3\end{array}$ & $\begin{array}{l}13 \\
18 \\
17 \\
10.5 \\
6\end{array}$ & $\begin{array}{c}11-38 \\
12-44 \\
13-64 \\
8-14 \\
4-6\end{array}$ & $\begin{array}{l}4 \\
9 \\
4 \\
4\end{array}$ \\
\hline $\begin{array}{l}15 \\
9.6 \\
8.4 \\
7.9 \\
--\end{array}$ & $\begin{array}{l}10 \\
10 \\
8.2 \\
7.6 \\
--\end{array}$ & $\begin{array}{c}8.8-24 \\
6.9-13 \\
6-11 \\
5.4-10 \\
--\end{array}$ & $\begin{array}{r}5 \\
5 \\
4 \\
7 \\
--\end{array}$ & $\begin{array}{r}22 \\
7.3 \\
9.3 \\
6.8 \\
4.9\end{array}$ & $\begin{array}{c}19 \\
8.2 \\
9.6 \\
6.8 \\
--\end{array}$ & $\begin{array}{l}17-29 \\
5.4-8.8 \\
7.3-11 \\
5.5-8.3 \\
4.9\end{array}$ & $\begin{array}{l}5 \\
8 \\
5 \\
6 \\
1\end{array}$ & $\begin{array}{c}24 \\
16 \\
15 \\
8.3 \\
15\end{array}$ & $\begin{array}{r}24 \\
13 \\
12 \\
9 \\
16\end{array}$ & $\begin{array}{r}9.9-40 \\
7.2-37 \\
6-29 \\
3.5-12 \\
3.9-34\end{array}$ & $\begin{array}{r}9 \\
16 \\
8 \\
8 \\
7\end{array}$ \\
\hline $\begin{array}{l}5.7 \\
4.5 \\
3.7 \\
4.2 \\
--\end{array}$ & $\begin{array}{l}5.5 \\
3.8 \\
3.5 \\
4.1 \\
--\end{array}$ & $\begin{array}{c}2.8-10 \\
3-6.5 \\
2.5-5.2 \\
2.4-6 \\
\quad--\end{array}$ & $\begin{array}{r}5 \\
5 \\
4 \\
7 \\
--\end{array}$ & $\begin{array}{l}7.1 \\
5 \\
4.6 \\
5.8 \\
7\end{array}$ & $\begin{array}{l}7.1 \\
5 \\
4.3 \\
5 \\
--\end{array}$ & $\begin{array}{l}4.7-9.1 \\
3.4-6 \\
3.3-6.4 \\
4.7-7.5 \\
7\end{array}$ & $\begin{array}{l}5 \\
8 \\
5 \\
6 \\
1\end{array}$ & $\begin{array}{l}9.6 \\
8.6 \\
8.8 \\
7.2 \\
6.8\end{array}$ & $\begin{array}{l}9.2 \\
7.6 \\
5 \\
6.2 \\
7.5\end{array}$ & $\begin{array}{l}5-16 \\
3.7-25 \\
3.6-23 \\
3.6-13 \\
3.5-9.7\end{array}$ & $\begin{array}{r}9 \\
16 \\
8 \\
8 \\
7\end{array}$ \\
\hline $\begin{array}{l}.1 \\
.1 \\
.1 \\
<.1 \\
--\end{array}$ & $\begin{array}{c}.1 \\
.1 \\
.1 \\
.1 \\
-.\end{array}$ & $\begin{array}{c}.1 \\
.1-.2 \\
.1-.2 \\
<.1-.1 \\
--\end{array}$ & $\begin{array}{r}5 \\
5 \\
4 \\
6 \\
--\end{array}$ & $\begin{array}{l}.2 \\
.2 \\
.2 \\
<.2 \\
.10\end{array}$ & $\begin{array}{c}.2 \\
.2 \\
.2 \\
.1 \\
--\end{array}$ & $\begin{array}{c}.1-.2 \\
.1-.3 \\
.1-.3 \\
<.1-.2 \\
.10\end{array}$ & $\begin{array}{l}5 \\
8 \\
5 \\
6 \\
1\end{array}$ & $\begin{array}{l}.2 \\
.1 \\
.2 \\
.1 \\
.1\end{array}$ & $\begin{array}{l}.2 \\
.1 \\
.2 \\
.1 \\
.1\end{array}$ & $\begin{array}{l}.1-.3 \\
.1-.3 \\
.1-.3 \\
.1-.2 \\
.1-.2\end{array}$ & $\begin{array}{r}9 \\
16 \\
8 \\
8 \\
7\end{array}$ \\
\hline $\begin{array}{l}3.8 \\
3.4 \\
2.4 \\
3.7 \\
--\end{array}$ & $\begin{array}{l}2.6 \\
3 \\
2.4 \\
3.2 \\
--\end{array}$ & $\begin{array}{c}2-6 \\
2-4.9 \\
1.9-2.9 \\
2.6-5.1 \\
--\end{array}$ & $\begin{array}{r}5 \\
5 \\
4 \\
7 \\
--\end{array}$ & $\begin{array}{l}4.7 \\
3.3 \\
3 \\
4.9 \\
5.1\end{array}$ & $\begin{array}{l}4.6 \\
3.4 \\
2.7 \\
5 \\
--\end{array}$ & $\begin{array}{c}3-6.4 \\
2.3-4.2 \\
2.6-4.2 \\
3.5-6.4 \\
5.1\end{array}$ & $\begin{array}{l}5 \\
8 \\
4 \\
6 \\
1\end{array}$ & $\begin{array}{l}6.1 \\
5.2 \\
4.9 \\
5.1 \\
5.6\end{array}$ & $\begin{array}{l}5.6 \\
4.6 \\
4.1 \\
5 \\
6.6\end{array}$ & $\begin{array}{l}3.8-9.6 \\
2.2-11 \\
3-10 \\
3.6-7.1 \\
2.3-8.5\end{array}$ & $\begin{array}{r}9 \\
16 \\
8 \\
8 \\
7\end{array}$ \\
\hline $\begin{array}{c}75 \\
65 \\
48 \\
56 \\
--\end{array}$ & $\begin{array}{c}60 \\
54 \\
46 \\
54 \\
--\end{array}$ & $\begin{array}{l}50-130 \\
49-93 \\
44-56 \\
45-74 \\
--\end{array}$ & $\begin{array}{r}5 \\
5 \\
4 \\
7 \\
--\end{array}$ & $\begin{array}{l}94 \\
64 \\
62 \\
61 \\
63\end{array}$ & $\begin{array}{c}98 \\
67 \\
62 \\
59 \\
--\end{array}$ & $\begin{array}{c}71-122 \\
53-75 \\
50-79 \\
49-83 \\
63\end{array}$ & $\begin{array}{l}5 \\
8 \\
5 \\
6 \\
1\end{array}$ & $\begin{array}{r}100 \\
87 \\
87 \\
65 \\
67\end{array}$ & $\begin{array}{l}98 \\
82 \\
66 \\
64 \\
65\end{array}$ & $\begin{array}{l}68-147 \\
50-196 \\
62-163 \\
47-86 \\
46-89\end{array}$ & $\begin{array}{r}9 \\
16 \\
8 \\
8 \\
7\end{array}$ \\
\hline
\end{tabular}




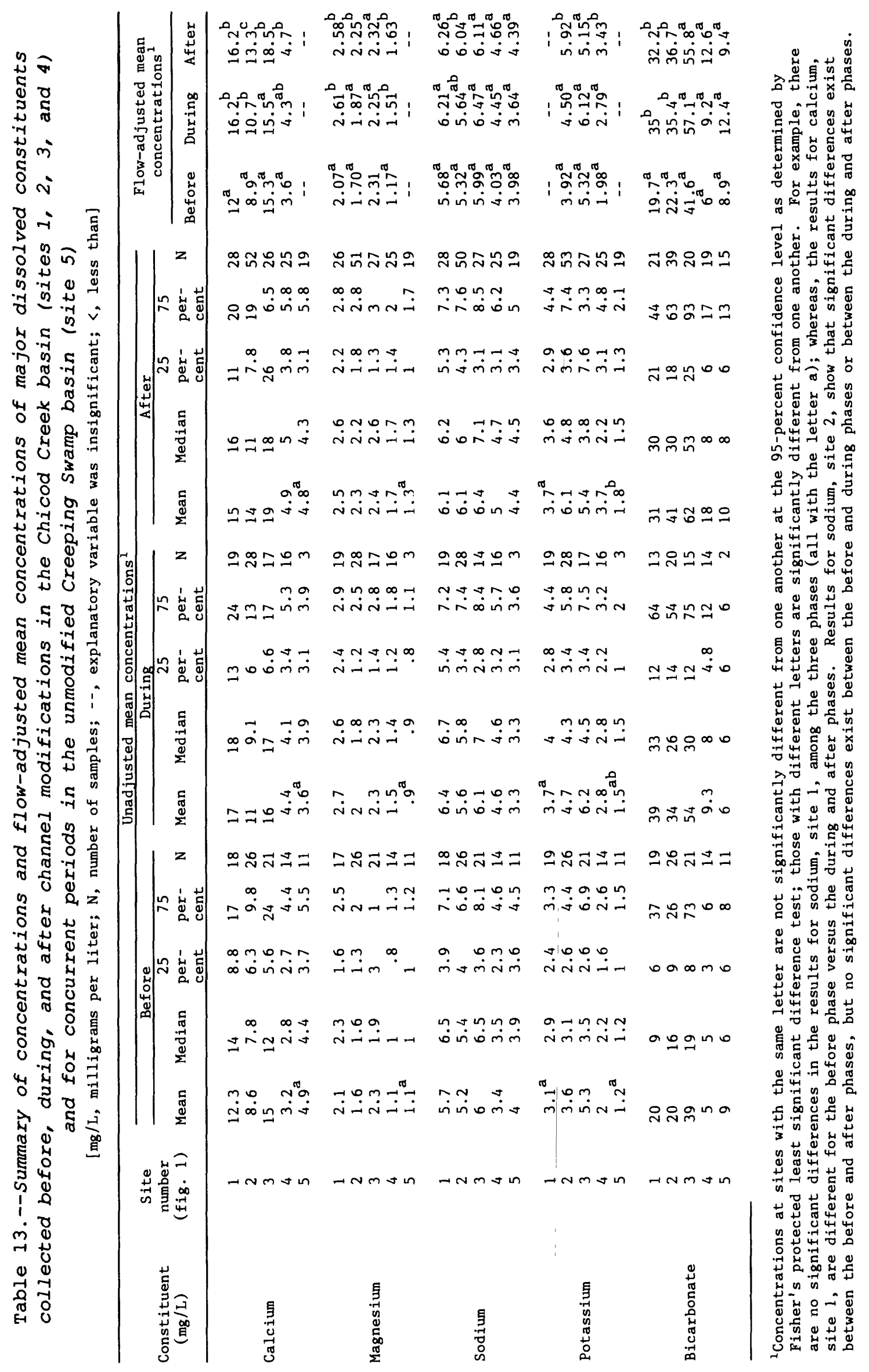




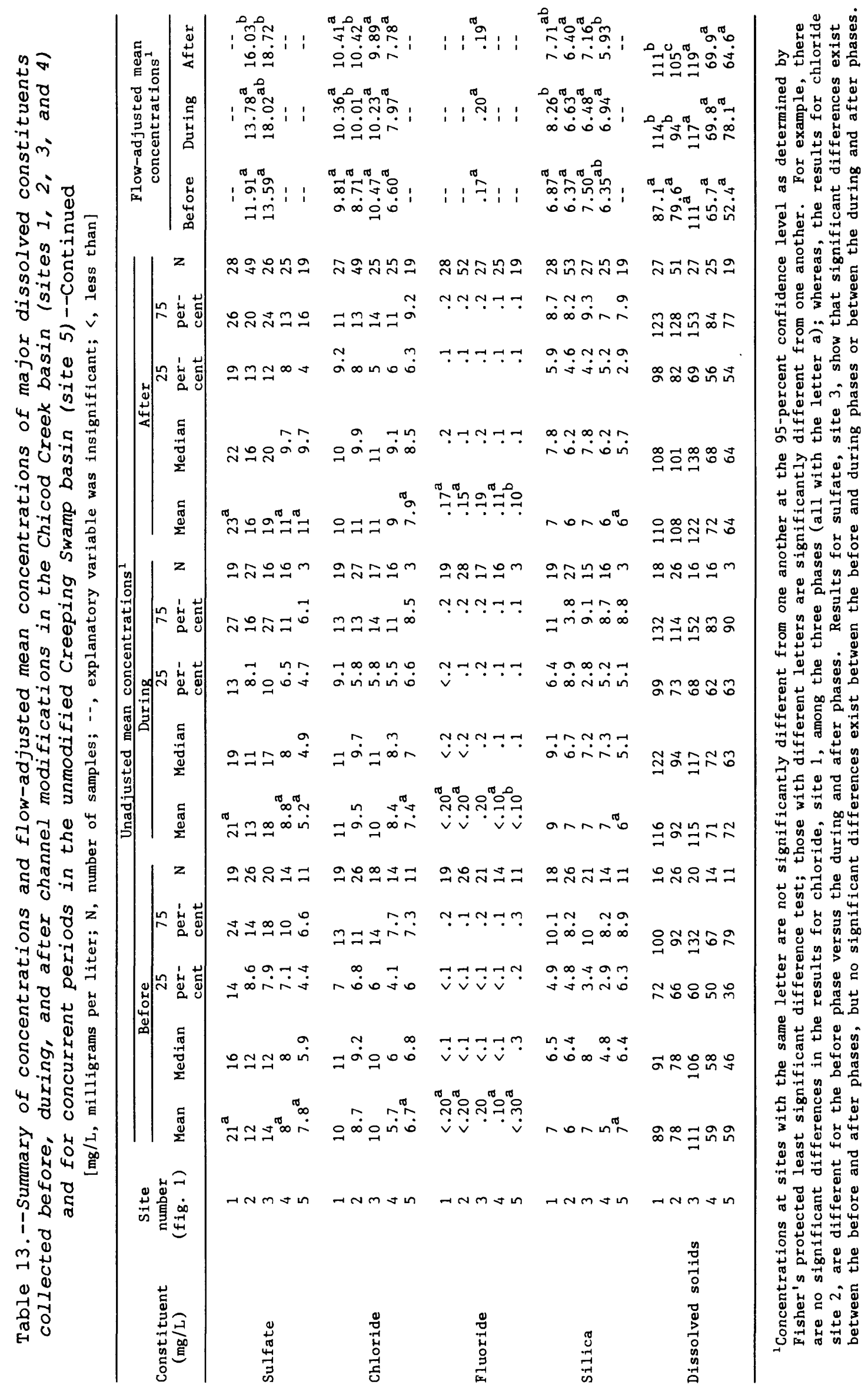


More changes in the concentration of major dissolved constituents occurred at Juniper Branch (site 1) during channel modifications than at the other sampling sites (table 13). Analysis of variance or covariance analysis reveals that of the 10 dissolved constituents measured, concentrations of 5 constituents increased significantly at the 95 -percent confidence level during channel excavation. For example, the flow-adjusted mean concentration of calcium increased from $12.0 \mathrm{mg} / \mathrm{L}$ (table 13) before modification to $16.2 \mathrm{mg} / \mathrm{L}$ during modification, an increase of 35 percent. Increases in other flow-adjusted mean concentrations during the modification period were: magnesium, 26 percent; bicarbonate, 78 percent; silica, 20 percent; and dissolved solids, 31 percent. No significant change in the concentration of any dissolved constituent was detected when comparing concentrations during modifications to those after modifications.

A comparison of the flow-adjusted concentrations of dissolved constituents before channel modification with concentrations after modification at Juniper Branch (table 13) indicated an overall increase in calcium of 35 percent; magnesium, 25 percent; bicarbonate, 63 percent; silica, 12 percent; and dissolved solids, 27 percent. For these constituents, the greatest increases occurred during the excavation phase.

Increases in the concentrations of major dissolved constituents at Juniper Branch are probably related to the degree of channel excavation and the shallow depths to marine deposits beneath the stream bed. of the four modified sites, Juniper Branch was the most extensively channelized. Almost all of the stream reaches upstream of the site were excavated. Furthermore, examination of drilling records of $\mathrm{Pi}-527$ indicate that the top of the Yorktown Formation is at an elevation of $19 \mathrm{ft}$ above mean sea level, approximately 1 to $2 \mathrm{ft}$ below the average elevation of the Juniper Branch flood plain at site 1 near the well. Excavations of the streambed exposed fossil shell beds at several points along Juniper Branch, which were probably part of the Yorktown Formation. These she11s are composed primarily of calcium carbonate, and it is likely that the exposure and subsequent weathering of these shells contributed to the increased concentrations of calcium, magnesium, bicarbonate, and dissolved solids that were observed.

Changes in flow-adjusted concentrations of the major dissolved constituents at site 2 on Chicod Creek reflect the influence of a 7 -mile segment of the stream immediately above the site that was snagged and cleared to remove dead trees and channel blockages. Fewer and smaller 
percentage changes in concentrations of dissolved constituents occurred at this site during modifications than at Juniper Branch. Covariance analysis reveals that statistically significant increases in flow-adjusted mean concentrations during the excavation period, as compared to those prior to excavation, were (table 13): calcium, 20 percent; bicarbonate, 59 percent; chloride, 15 percent; and dissolved solids, 18 percent. Significant increases in some constituents also are apparent when comparing after to during modification concentrations. Increases include: calcium, 24 percent; magnesium, 20 percent; potassium, 32 percent; sulfate, 16 percent; and dissolved solids, 12 percent. A comparison of before and after modifications data indicates that significant overall increases in constituent concentrations at site 2 were: calcium, 49 percent; magnesium, 32 percent; sodium, 14 percent; potassium, 51 percent; bicarbonate, 64 percent; sulfate, 34 percent; chloride, 20 percent; and dissolved solids, 32 percent.

Concentrations of nearly all dissolved constituents were higher and the range in concentrations was somewhat broader (table 12) at Cow Swamp (site 3 ) than at the other sites. No statistically significant changes in concentrations were detected at this site when before-modification flowadjusted concentrations were compared to during-modification flow-adjusted concentrations (table 13). When during-modification concentrations were compared with after-modification concentrations, only calcium, which increased 19 percent, showed a significant change. The only significant overall increases at site 3 during the study were calcium (21 percent) and sulfate ( 38 percent) (table 13).

Flow-adjusted concentrations of dissolved constituents at the upstream Chicod Creek site (site 4) appear to be substantially less than those observed at other sites before excavation. This pattern continued throughout the study. The only dissolved constituent to change significantly during modification was magnesium, which increased 29 percent (table 13). After modifications, an increase was noted in potassium (23 percent); however, silica decreased approximately 15 percent during the same period. Overall significant increases in major dissolved constituents were: calcium, 31 percent; magnesium, 39 percent; and potassium, 73 percent.

Chicod Creek was extensively channelized along its headwaters near site 4 but generally to a shallower depth than at Juniper Branch. Furthermore, the Yorktown Formation was more deeply buried in the headwaters area. Therefore, the channelized upstream segments of Chicod Creek did not incise 
shell beds of this formation and the concentrations of most of the major dissolved constituents remained unchanged.

With the exception of potassium and fluoride, there were no significant changes in major dissolved constituents in the control basin, Creeping Swamp (site 5) as determined through analysis of variance (table 13). A comparison of unadjusted means for before and after channel modification indicates that potassium increased about 50 percent and fluoride decreased about 33 percent. Flow-adjusted means are not available for these constituents at Creeping Swamp, and it is not known whether these changes might be accounted for by differences in flow or are due to some other cause.

\section{Nutrients}

Nutrients, such as various nitrogen and phosphorus species, are transported in both dissolved and suspended forms. In the suspended state, most nutrients are attached to soil or sediment particles. During base-flow periods, these particles lie undisturbed on the ground or in the streambed. During high-flow periods or when the streambed is physically disturbed, the particles become suspended, causing the total concentrations of nutrients in the water column to increase. For this reason, nutrients in streams often reach maximum concentrations during high-flow periods.

During base-flow periods in the Chicod Creek basin, high dissolved nutrient concentrations may occur where livestock have direct access to some streams for watering purposes and directly input solid and liquid waste to the stream. These wastes are a significant source of various forms of nitrogen. But in most cases, total nutrient concentrations were generally higher during high-flow periods than base-flow periods (table 14).

Significant increases in flow-adjusted nutrient concentrations during or after modifications were observed only at Juniper Branch (site 1) and Chicod Creek (site 2) as revealed by an analysis of covariance or analysis of variance. No changes in nutrient concentrations were detected at Cow Swamp (site 3) upstream Chicod Creek (site 4) or Creeping Swamp (site 5) (table 15).

During modifications, flow-adjusted total nitrogen concentrations at Juniper Branch (site 1) rose from 2.32 to $3.46 \mathrm{mg} / \mathrm{L}$, an increase of 49 percent from premodification levels (table 15). Unadjusted total nitrite, total nitrate, and flow-adjusted total $\mathrm{Kjeldahl}$ nitrogen also increased 
Table 14.--Summary statistics for concentrations of nutrients during selected base-flow and high-flow periods before, during, and after channel modifications in the Chicod Creek basin (sites 1, 2, 3, and 4) and for concurrent periods in the unmodified Creeping Swamp basin (site 5)

[mg/L, milligrams per liter; $N$, number of samples; <, less than; -- , insufficient data]

\begin{tabular}{|c|c|c|c|c|c|c|c|c|c|c|c|c|c|}
\hline \multirow{2}{*}{$\begin{array}{l}\text { Nutrient } \\
(\mathrm{mg} / \mathrm{L})\end{array}$} & \multirow{2}{*}{$\begin{array}{c}\text { Site } \\
\text { number } \\
\text { (fig. 1) }\end{array}$} & \multicolumn{4}{|c|}{ Before } & \multicolumn{4}{|c|}{ During } & \multicolumn{4}{|c|}{ After } \\
\hline & & Mean & Median & Range & $\mathbf{N}$ & Mean & Median & Range & $\mathrm{N}$ & Mean & Median & Range & $\mathrm{N}$ \\
\hline \multicolumn{14}{|c|}{ Base flow } \\
\hline $\begin{array}{l}\text { Total nitrite } \\
\text { as nitrogen }\end{array}$ & $\begin{array}{l}1 \\
2 \\
3 \\
4 \\
5\end{array}$ & $\begin{array}{c}<0.02 \\
.02 \\
.05 \\
.01 \\
-.\end{array}$ & $\begin{array}{l}<0.01 \\
.02 \\
.04 \\
-- \\
--\end{array}$ & $\begin{array}{c}<0.01-0.02 \\
.01-.02 \\
.01-.08 \\
.01 \\
--\end{array}$ & $\begin{array}{r}4 \\
5 \\
5 \\
1 \\
--\end{array}$ & $\begin{array}{r}0.03 \\
.02 \\
.03 \\
<.02 \\
--\end{array}$ & $\begin{array}{r}0.02 \\
.02 \\
.01 \\
.01 \\
-.\end{array}$ & $\begin{array}{c}0.01-0.06 \\
.00-.05 \\
.00-.10 \\
<.01-.04 \\
-.\end{array}$ & $\begin{array}{r}5 \\
5 \\
4 \\
4 \\
--\end{array}$ & $\begin{array}{l}0.05 \\
.05 \\
.14 \\
.07 \\
.01\end{array}$ & $\begin{array}{l}0.05 \\
.03 \\
.08 \\
.06 \\
.01\end{array}$ & $\begin{array}{c}0.02-0.07 \\
.01-.13 \\
.08-.27 \\
.04-.10 \\
.01-.02\end{array}$ & $\begin{array}{l}4 \\
8 \\
3 \\
3 \\
3\end{array}$ \\
\hline $\begin{array}{l}\text { Total nitrate } \\
\text { as nitrogen }\end{array}$ & $\begin{array}{l}1 \\
2 \\
3 \\
4 \\
5\end{array}$ & $\begin{array}{l}.54 \\
.83 \\
.57 \\
.17 \\
. .\end{array}$ & $\begin{array}{l}.36 \\
.76 \\
.33 \\
-. \\
--\end{array}$ & $\begin{array}{c}.13-1.3 \\
.05-1.2 \\
.08-1.4 \\
.17 \\
--\end{array}$ & $\begin{array}{r}4 \\
5 \\
5 \\
1 \\
--\end{array}$ & $\begin{array}{l}2.1 \\
1.5 \\
1.3 \\
.67 \\
--\end{array}$ & $\begin{array}{l}2.1 \\
1.4 \\
1.3 \\
.74 \\
\therefore .\end{array}$ & $\begin{array}{c}1.4-2.9 \\
.95-2.2 \\
.07-2.5 \\
.06-1.2 \\
\ldots\end{array}$ & $\begin{array}{r}5 \\
5 \\
5 \\
3 \\
--\end{array}$ & $\begin{array}{l}2 \\
2.6 \\
1.5 \\
1.1 \\
0\end{array}$ & $\begin{array}{l}1.7 \\
2.7 \\
1.5 \\
.75 \\
. .\end{array}$ & $\begin{array}{c}1.4-3.1 \\
.78-4.2 \\
.82-2.2 \\
.66-2 \\
0\end{array}$ & $\begin{array}{l}4 \\
7 \\
3 \\
3 \\
1\end{array}$ \\
\hline Total nitrogen & $\begin{array}{l}1 \\
2 \\
3 \\
4 \\
5\end{array}$ & $\begin{array}{l}1.1 \\
1.6 \\
6.7 \\
2.2 \\
--\end{array}$ & $\begin{array}{l}.88 \\
1.5 \\
3.8 \\
.87 \\
--\end{array}$ & $\begin{array}{l}.49-2 \\
.83-2.2 \\
.89-25 \\
.84-5 \\
--\end{array}$ & $\begin{array}{r}6 \\
5 \\
6 \\
3 \\
--\end{array}$ & $\begin{array}{l}3.1 \\
2.9 \\
6.8 \\
1.9 \\
--\end{array}$ & $\begin{array}{l}2.6 \\
3 \\
3.8 \\
1.8 \\
--\end{array}$ & $\begin{array}{l}2.2-4.5 \\
2.2-3.7 \\
2.7-19 \\
1.3-2.7 \\
\quad--\end{array}$ & $\begin{array}{r}5 \\
5 \\
5 \\
4 \\
--\end{array}$ & $\begin{array}{l}3 \\
3.9 \\
5.2 \\
8.8 \\
1\end{array}$ & $\begin{array}{l}2.2 \\
3.7 \\
6 \\
7.2 \\
.-\end{array}$ & $\begin{array}{c}1.8-5.8 \\
1.5-6.9 \\
2.3-7.4 \\
5.2-14 \\
1\end{array}$ & $\begin{array}{l}4 \\
9 \\
3 \\
3 \\
1\end{array}$ \\
\hline $\begin{array}{l}\text { Total kjeldahl } \\
\text { nitrogen } \\
\text { as nitrogen }\end{array}$ & $\begin{array}{l}1 \\
2 \\
3 \\
4 \\
5\end{array}$ & $\begin{array}{l}.62 \\
1 \\
6.3 \\
.98 \\
--\end{array}$ & $\begin{array}{c}.54 \\
.95 \\
2.9 \\
.78 \\
-.\end{array}$ & $\begin{array}{c}.37-1.1 \\
.76-1.3 \\
.80-25 \\
.66-1.5 \\
--\end{array}$ & $\begin{array}{r}8 \\
6 \\
6 \\
3 \\
--\end{array}$ & $\begin{array}{l}.96 \\
1.5 \\
5.5 \\
1.1 \\
-.\end{array}$ & $\begin{array}{l}.84 \\
1.4 \\
2.5 \\
1.1 \\
--\end{array}$ & $\begin{array}{c}.5-1.8 \\
.9-2.6 \\
1.6-19 \\
.68-1.5 \\
--\end{array}$ & $\begin{array}{r}5 \\
6 \\
5 \\
4 \\
--\end{array}$ & $\begin{array}{l}1 \\
1.4 \\
3.6 \\
7.5 \\
.9\end{array}$ & $\begin{array}{l}.5 \\
1.1 \\
4.4 \\
5.1 \\
1\end{array}$ & $\begin{array}{c}.4-2.6 \\
.7-3.5 \\
1.4-4.9 \\
4.4-13 \\
.5-1.2\end{array}$ & $\begin{array}{l}4 \\
9 \\
3 \\
3 \\
3\end{array}$ \\
\hline Total phosphorus & $\begin{array}{l}1 \\
2 \\
3 \\
4 \\
5\end{array}$ & $\begin{array}{c}.13 \\
.24 \\
1.3 \\
.05 \\
-.\end{array}$ & $\begin{array}{c}.16 \\
.23 \\
1.2 \\
.05 \\
-.\end{array}$ & $\begin{array}{c}.02-.20 \\
.16-.38 \\
.60-2.6 \\
.04-.06 \\
--\end{array}$ & $\begin{array}{r}6 \\
6 \\
6 \\
3 \\
--\end{array}$ & $\begin{array}{r}.12 \\
.37 \\
.85 \\
.09 \\
--\end{array}$ & $\begin{array}{l}.09 \\
.40 \\
.59 \\
.09 \\
-.\end{array}$ & $\begin{array}{c}.08-.20 \\
.21-.49 \\
.35-2.2 \\
.03-.15 \\
--\end{array}$ & $\begin{array}{r}5 \\
6 \\
5 \\
4 \\
--\end{array}$ & $\begin{array}{l}.18 \\
.51 \\
.42 \\
.28 \\
.03\end{array}$ & $\begin{array}{l}.20 \\
.43 \\
.43 \\
.28 \\
.04\end{array}$ & $\begin{array}{l}.09-.24 \\
.35-1.10 \\
.31-.54 \\
.24-.31 \\
.01-.05\end{array}$ & $\begin{array}{l}4 \\
9 \\
3 \\
3 \\
3\end{array}$ \\
\hline
\end{tabular}

\begin{tabular}{|c|c|c|c|c|c|c|c|c|c|c|c|c|c|}
\hline \multicolumn{14}{|c|}{ High flow } \\
\hline $\begin{array}{l}\text { Total nitrite } \\
\text { as nitrogen }\end{array}$ & $\begin{array}{l}1 \\
2 \\
3 \\
4 \\
5\end{array}$ & $\begin{array}{l}0.05 \\
.04 \\
.06 \\
.04 \\
-.\end{array}$ & $\begin{array}{l}0.03 \\
.04 \\
.06 \\
.03 \\
-.\end{array}$ & $\begin{array}{c}0.02-0.12 \\
.01-.07 \\
.02-.12 \\
.01-.06 \\
--\end{array}$ & $\begin{array}{r}6 \\
7 \\
5 \\
7 \\
--\end{array}$ & $\begin{array}{l}0.05 \\
.08 \\
.07 \\
.04 \\
.03\end{array}$ & $\begin{array}{l}0.06 \\
.09 \\
.08 \\
.05 \\
--\end{array}$ & $\begin{array}{c}0.01-0.09 \\
.01-.13 \\
.01-.11 \\
.00-.07 \\
.03\end{array}$ & $\begin{array}{l}4 \\
5 \\
4 \\
5 \\
1\end{array}$ & $\begin{array}{l}0.06 \\
.06 \\
.06 \\
.03 \\
.02\end{array}$ & $\begin{array}{l}0.04 \\
.06 \\
.05 \\
.02 \\
.02\end{array}$ & $\begin{array}{c}0.02-0.24 \\
.01-.16 \\
.02-.15 \\
.01-.05 \\
.01-.03\end{array}$ & $\begin{array}{r}8 \\
14 \\
7 \\
7 \\
6\end{array}$ \\
\hline $\begin{array}{l}\text { Total nitrate } \\
\text { as nitrogen }\end{array}$ & $\begin{array}{l}1 \\
2 \\
3 \\
4 \\
5\end{array}$ & $\begin{array}{l}1.7 \\
.80 \\
.60 \\
.50 \\
--\end{array}$ & $\begin{array}{l}1.1 \\
.70 \\
.56 \\
.39 \\
-.\end{array}$ & $\begin{array}{c}.64-4.8 \\
.30-1.9 \\
.43-.88 \\
.15-1.6 \\
--\end{array}$ & $\begin{array}{r}6 \\
7 \\
5 \\
7 \\
--\end{array}$ & $\begin{array}{l}1.8 \\
.84 \\
1.1 \\
.70 \\
.20\end{array}$ & $\begin{array}{l}1.8 \\
.99 \\
1 \\
.51 \\
-.\end{array}$ & $\begin{array}{c}1.1-2.3 \\
.41-1.2 \\
.55-1.6 \\
.44-.92 \\
.20\end{array}$ & $\begin{array}{l}4 \\
5 \\
4 \\
5 \\
1\end{array}$ & $\begin{array}{l}2.1 \\
1.3 \\
.86 \\
.59 \\
.18\end{array}$ & $\begin{array}{l}2.2 \\
1.1 \\
.85 \\
.62 \\
.18\end{array}$ & $\begin{array}{l}.58-4.6 \\
.47-3.4 \\
.28-1.3 \\
.30-.85 \\
.17-.18\end{array}$ & $\begin{array}{r}8 \\
13 \\
7 \\
6 \\
2\end{array}$ \\
\hline Total nitrogen & $\begin{array}{l}1 \\
2 \\
3 \\
4 \\
5\end{array}$ & $\begin{array}{l}3.5 \\
2.5 \\
3 \\
2 \\
--\end{array}$ & $\begin{array}{l}2.8 \\
2.2 \\
2.3 \\
1.6 \\
--\end{array}$ & $\begin{array}{c}1.8-6.2 \\
1.3-3.9 \\
1.6-5.2 \\
.75-3.3 \\
--\end{array}$ & $\begin{array}{r}5 \\
7 \\
5 \\
7 \\
--\end{array}$ & $\begin{array}{l}3.7 \\
3.8 \\
3.1 \\
2.2 \\
1.1\end{array}$ & $\begin{array}{l}3.2 \\
3 \\
3.1 \\
1.8 \\
-.\end{array}$ & $\begin{array}{c}2.8-5.5 \\
2.1-6.5 \\
2.1-4.2 \\
1.5-4.2 \\
\quad 1.1\end{array}$ & $\begin{array}{l}5 \\
8 \\
5 \\
6 \\
1\end{array}$ & $\begin{array}{l}3.9 \\
4.6 \\
3.5 \\
1.9 \\
1.4\end{array}$ & $\begin{array}{l}3.9 \\
3.7 \\
2.8 \\
1.8 \\
1.4\end{array}$ & $\begin{array}{c}1.5-6.7 \\
2-20 \\
1.1-7.1 \\
1.2-2.8 \\
.6-2.5\end{array}$ & $\begin{array}{r}9 \\
15 \\
8 \\
8 \\
4\end{array}$ \\
\hline $\begin{array}{l}\text { Tota1 kjeldah1 } \\
\text { nitrogen } \\
\text { as nitrogen }\end{array}$ & $\begin{array}{l}1 \\
2 \\
3 \\
4 \\
5\end{array}$ & $\begin{array}{l}1.7 \\
1.6 \\
2.3 \\
1.4 \\
--\end{array}$ & $\begin{array}{l}1.4 \\
1.6 \\
1.7 \\
1.3 \\
--\end{array}$ & $\begin{array}{c}.83-3.5 \\
1-25 \\
.99-4.4 \\
.60-2.8 \\
--\end{array}$ & $\begin{array}{r}6 \\
7 \\
5 \\
7 \\
--\end{array}$ & $\begin{array}{l}1.9 \\
2.7 \\
2 \\
1.4 \\
.86\end{array}$ & $\begin{array}{l}1.4 \\
1.8 \\
1.7 \\
1.2 \\
--\end{array}$ & $\begin{array}{c}.9-4.3 \\
1.4-5.3 \\
1.5-3 \\
.62-2.7 \\
.86\end{array}$ & $\begin{array}{l}5 \\
8 \\
5 \\
5 \\
1\end{array}$ & $\begin{array}{l}1.4 \\
3.1 \\
2.3 \\
1.1 \\
1\end{array}$ & $\begin{array}{r}1.2 \\
2.5 \\
1.8 \\
1.1 \\
.8\end{array}$ & $\begin{array}{c}.9-2 \\
1.1-16 \\
.8-4.5 \\
.7-1.6 \\
.4-2.3\end{array}$ & $\begin{array}{r}9 \\
15 \\
8 \\
8 \\
8\end{array}$ \\
\hline Total phosphorus & $\begin{array}{l}1 \\
2 \\
3 \\
4 \\
5\end{array}$ & $\begin{array}{l}.49 \\
.51 \\
.47 \\
.23 \\
-.\end{array}$ & $\begin{array}{l}.28 \\
.47 \\
.44 \\
.16 \\
--\end{array}$ & $\begin{array}{c}.16-.93 \\
.37-.63 \\
.37-.63 \\
.05-.48 \\
--\end{array}$ & $\begin{array}{r}6 \\
7 \\
5 \\
7 \\
--\end{array}$ & $\begin{array}{l}.62 \\
.64 \\
.84 \\
.20 \\
.16\end{array}$ & $\begin{array}{l}.35 \\
.65 \\
.92 \\
.23 \\
-.\end{array}$ & $\begin{array}{c}.18-2 \\
.19-1.1 \\
.21-1.6 \\
.06-.30 \\
.16\end{array}$ & $\begin{array}{l}5 \\
8 \\
5 \\
6 \\
1\end{array}$ & $\begin{array}{l}.31 \\
.56 \\
.58 \\
.18 \\
.08\end{array}$ & $\begin{array}{l}.31 \\
.56 \\
.50 \\
.18 \\
.07\end{array}$ & $\begin{array}{l}.20-.54 \\
.28-.94 \\
.36-1.2 \\
.07-.29 \\
.04-.13\end{array}$ & $\begin{array}{r}9 \\
16 \\
8 \\
8 \\
8\end{array}$ \\
\hline
\end{tabular}




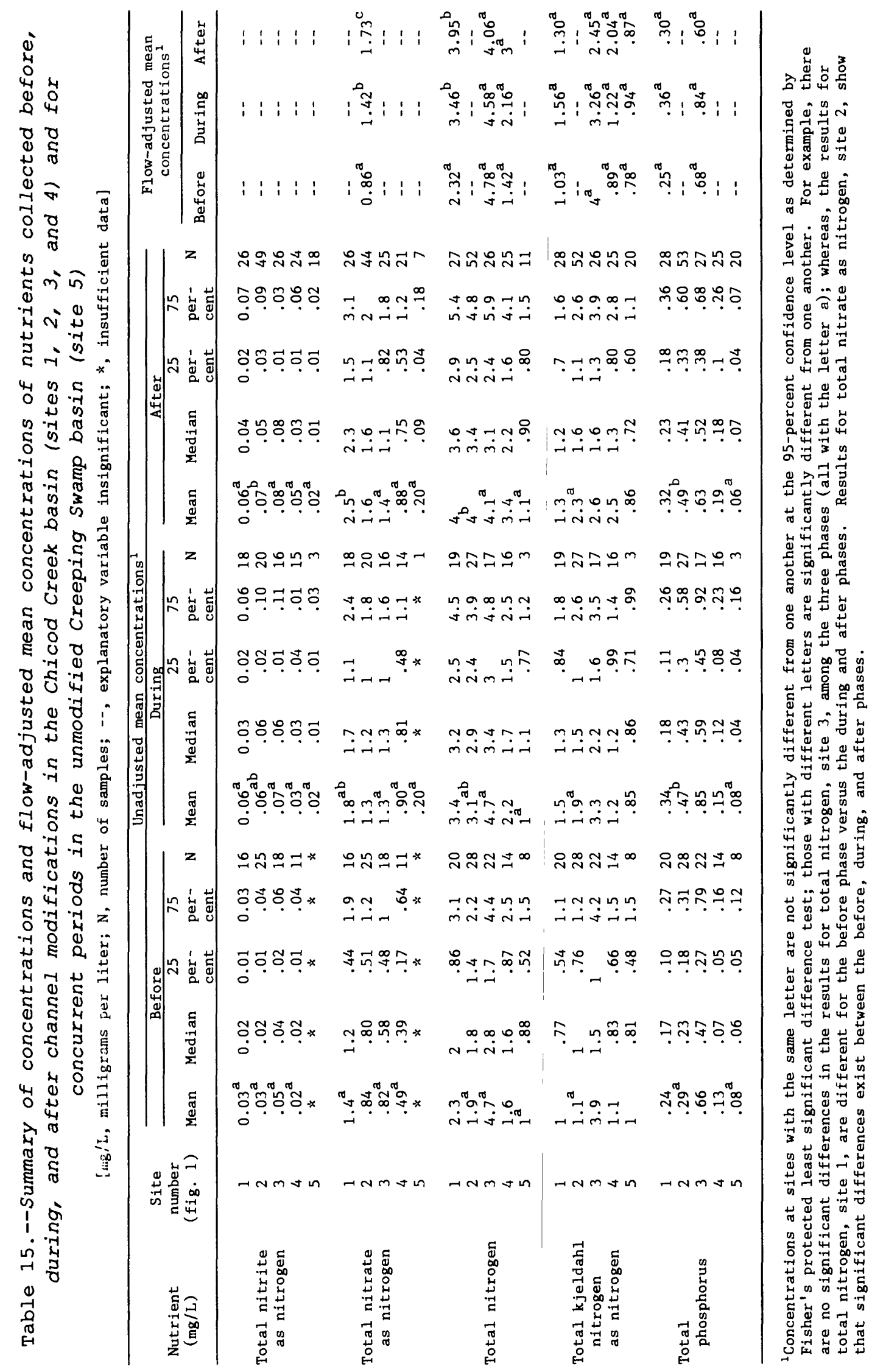


during this period, but the increases were not statistically significant at the 95-percent confidence leve1. After modifications, the increase in unadjusted total nitrate and flow-adjusted total nitrogen concentrations over premodification concentrations were statistically significant and were 70 and 78 percent, respectively.

Concentrations of most nitrogen species increased more at Chicod Creek (site 2) than at Juniper Branch, both in terms of percentages and absolute values. Flow-adjusted total nitrate concentrations at site 2 increased from 0.86 to $1.42 \mathrm{mg} / \mathrm{L}$, a 65 -percent increase during modification; unadjusted total nitrite and unadjusted total nitrogen concentrations showed smaller increases (table 15). Statistically significant increases were detected at site 2 only when comparing before-modification concentrations with aftermodification concentrations. These increases were: unadjusted total nitrite, 130 percent; flow-adjusted total nitrate, 100 percent; and unadjusted total nitrogen, 110 percent.

Chicod Creek (site 2) was the only site where statistically significant increases in total phosphorus concentrations were detected. Unadjusted total phosphorus concentrations at this site increased 62 percent during modification compared with premodification concentrations, but no statistically significant increase occurred in the after-modification phase. The overall increase was 69 percent (table 15).

The increased concentration of nitrogen compounds observed at Juniper Branch (site 1) and Chicod Creek (site 2) after channel modifications may be related to livestock populations in the basin, to agricultural fertilizer applications, to seepage from septic tanks, and to changes in various nitrogen cycling processes brought about by the channel modifications. These sources are not quantifiable but could be major contributors of nitrogen to these streams as discussed below.

Agricultural statistics for Pitt and Beaufort Counties indicate that poultry populations nearly doubled during the study period and that pork populations have increased by appoximately 60 percent (North Carolina Department of Agriculture, 1976a-annually). Increases in these populations in the Chicod Creek basin probably exceeded county-wide averages (Albert Coffey, U.S. Department of Agriculture, SCS, oral commun., 1987). Total nitrite concentrations increased at site 2 after channel modification and may have originated from livestock wastes observed near the sampling site. Oxidation of organic nitrogen, ammonia, and nitrite compounds in the wastes during stream transport could also account for the nitrate concentrations 
observed along Chicod Creek during the study period. At Juniper Branch, however, increases in nitrate concentrations were detected where no substantial increase in livestock populations occurred, which indicates that sources other than animal wastes are contibuting nitrates to that stream.

The amount of fertilizer chemicals shipped to Pitt and Beaufort Counties declined steadily during the study period (North Carolina Department of Agriculture, 1976b-annual1y). Fertilizer applications in fields bordering Juniper Branch probably followed this trend (Albert Coffey, U.S. Department of Agriculture, SCS, oral commun., 1987). A1so, no improvements were made to drainage systems leading to Juniper Branch, such as the installation of drain tile or surface ditching, that could increase leaching of fertilizer nitrates. Thus, increases in the contributions of fertilizer-nitrogen species to streams in the Chicod Creek basin were likely minimal during the study period and probably were not responsible for the increases in nitrates observed.

Septic tank seepage from some of the 30 to 50 new homes built along the headwaters of Juniper Branch during the study may be responsible for some of the increase in nitrogen compounds. Some of these homes are as close as 300 ft to the stream. Carlile and others (1981) report that researchers have detected nitrates as much as $235 \mathrm{ft}$ from septic tank drainfields and that nitrates occasionally migrate $100 \mathrm{ft}$ or more from the fields when the water table is seasonally high and soil texture is coarse as in the case of the upstream areas of the Juniper Branch basin.

Changes in various nitrogen cycling processes brought about by the channel modifications is a fourth possible source of increases of nitrates (Kuenzler and others, 1977; Humenik and others, 1980). In anaerobic environments, faculative bacteria transform nitrates into nitrogen gas, which may then escape into the atmosphere. Without a microbic catalyst, nitrate can decompose into other forms of organic nitrogen, some of which is absorbed onto soil particles, particularly silts and clays, or on organic matter along the bed of the stream and in the flood plains (Wetze1, 1975). Over time, the concentrations of organic nitrogen compounds in the soil will build to an equilibrium in the anaerobic bottom sediments. During channel modifications, this reserve of organic nitrogen compounds may be exposed to air, nitrified to form nitrates, and then leached into the stream.

Another situation involving the same processes, is that channel modifications confine streamflow to an excavated channel that is stripped of nutrient removal processes. Nitrates in the stream then adjust to a new 
equilibrium, not as a result of deposition from exterior sources or nitrite conversions, but because they are no longer removed from the stream by the natural mechanisms of absorbtion, sediment deposition, nitrogen fixation, bacteriological transformation, and plant uptake in the flood plains. An important corollary to this idea is that the process should be reversible; an increase in exposure of the water to the flood plain because of channel fill-in and to newly established vegetation along stream banks and beds might tend to reduce the nitrate concentrations to levels observed before modification.

\section{Trace metals}

The term trace metal refers to metal solutes that, in natural water, nearly always occur in concentrations less than $1.0 \mathrm{mg} / \mathrm{L}$ (Hem, 1985). In streams, most of these constituents are generally attached to suspended sediment. Clay and organic matter especially act as significant collectors and concentrators of these metals (Horowitz, 1985). These particles are virtually undisturbed in the streambed during base-flow periods. During high-flow periods or when the streambed is physically disturbed, the particles become suspended and generally cause concentrations of trace metals in the water to increase (table 16).

Concentrations of some trace metals in the Chicod Creek basin increased as a result of channel modifications, while others decreased; some of the changes were significant, others were not. Total copper and total zinc concentrations increased during channel modifications, but these increases were not statistically significant. However, total iron and total lead concentrations decreased at most sites during the study. A comparison of concentrations before modification with those after modification at Juniper Branch (site 1) reveals that the flow-adjusted mean concentration of total iron decreased 77 percent, and the flow-adjusted concentration of total lead decreased 63 percent (table 17). The concentration of mercury also decreased during the study, but this decrease was a result of lower laboratory detection limits and probably does not represent an actual decline in the concentration of the constituent in the stream water.

Flow-adjusted mean concentrations of total lead and total iron also decreased at Chicod Creek (site 2) but less markedly. No statistically significant changes occurred during modifications, but after modifications, total iron concentrations decreased 57 percent as compared with concen- 
Table 16.--Summary statistics for concentrations of trace metals during selected base-flow and high-flow periods before, during, and after channel modifications in the Chicod Creek basin (sites 1, 2, 3, and 4) and for concurrent periods in the unmodified Creeping Swamp basin (site 5)

[ $\mu \mathrm{g} / \mathrm{L}$, micrograms per Liter; $N$, number of samples; <, less than; --, insufficient data]

\begin{tabular}{|c|c|c|c|c|c|c|c|c|c|c|c|c|c|}
\hline \multirow{2}{*}{$\begin{array}{c}\text { Trace metal } \\
(\mu \mathrm{g} / \mathrm{L})\end{array}$} & \multirow{2}{*}{$\begin{array}{c}\text { Site } \\
\text { number } \\
\text { (fig. 1) }\end{array}$} & \multicolumn{4}{|c|}{ Before } & \multicolumn{4}{|c|}{ During } & \multicolumn{4}{|c|}{ After } \\
\hline & & Mean & Median & Range & $\mathbf{N}$ & Mean & Median & Range & $\mathbf{N}$ & Mean & Median & Range & $\mathbf{N}$ \\
\hline \multicolumn{14}{|c|}{ Base flow } \\
\hline \multirow{5}{*}{ Total copper } & 1 & 2 & 2 & $0-3$ & 6 & 5 & 2 & $0-14$ & 5 & 3 & 2 & $1-5$ & 3 \\
\hline & 2 & 5 & 3 & $2-14$ & 6 & 9 & 7 & $0-20$ & 6 & 4 & 3 & $2-6$ & 7 \\
\hline & 3 & 3 & 2 & $2-6$ & 6 & $<3$ & 2 & $<2-7$ & 5 & 4 & 2 & $1-9$ & 3 \\
\hline & 4 & $<2$ & 2 & $<2-2$ & 3 & $<3$ & 1.5 & $<2-9$ & 4 & 3 & 3 & $1-4$ & 3 \\
\hline & 5 & -- & -- & -- & -- & -- & -- & -- & -- & 8 & 5 & $1-17$ & 3 \\
\hline \multirow{4}{*}{ Tota1 iron } & 1 & 1,000 & 1,100 & $500-1,400$ & 6 & 670 & 520 & $300-1,400$ & 5 & 580 & 580 & $520-630$ & 3 \\
\hline & 3 & 1,800 & 1,600 & $920-2,700$ & 6 & 1,100 & 1,100 & $530-2,100$ & 5 & 540 & 610 & $340-670$ & 3 \\
\hline & 4 & 1,000 & 550 & $100-2,500$ & 3 & 1,200 & 1,100 & $280-2,500$ & 4 & 2,100 & 2,000 & $1,400-2,800$ & 3 \\
\hline & 5 & -- & -- & -- & -- & -- & -- & -- & -- & 1,900 & 1,600 & $1,200-2,800$ & 3 \\
\hline \multirow{5}{*}{ Total lead } & 1 & 8 & 5 & $2-17$ & 6 & 3 & 2 & $0-9$ & 5 & 2 & 2 & $1-3$ & 4 \\
\hline & 2 & $<11$ & 9 & $<2-24$ & 6 & 9 & 7 & $3-13$ & 6 & 5 & 4 & $1-8$ & 8 \\
\hline & 3 & 8 & 8 & $0-15$ & 6 & 3 & 4 & $0-5$ & 5 & 3 & 4 & $1-4$ & 3 \\
\hline & 4 & 8 & 7 & $6-11$ & 3 & 2 & 3 & $0-4$ & 4 & 3 & 3 & $2-4$ & 3 \\
\hline & 5 & -- & -- & -- & -- & $\cdots$ & $\cdots$ & -- & -- & 4 & 4 & $3-6$ & 3 \\
\hline \multirow{5}{*}{ Total mercury } & 1 & $<.5$ & $<.5$ & $<.5-.5$ & 5 & $<.2$ & $<.1$ & $<.1-<.5$ & 5 & $<.1$ & $<.1$ & $<.1-<.1$ & 4 \\
\hline & 2 & $<.5$ & $<.5$ & $<.5-.5$ & 5 & $<.2$ & $<.1$ & $<.1-.5$ & 6 & .2 & .1 & $.1-.7$ & 8 \\
\hline & 3 & $<.5$ & $<.5$ & $<.5-.5$ & 3 & $<.3$ & $<.1$ & $<.1-<.5$ & 5 & .1 & .1 & $.1-.1$ & 3 \\
\hline & 4 & $<.5$ & $<.5$ & $<.5$ & 3 & $<.2$ & $<.1$ & $<.1-<.5$ & 4 & .2 & .1 & $.1-.40$ & 3 \\
\hline & 5 & -- & -- & -- & -- & -- & -- & -- & -- & .1 & .1 & $.1-.20$ & 3 \\
\hline \multirow{5}{*}{ Total zinc } & 1 & $<30$ & 20 & $<20-30$ & 6 & 60 & 20 & $10-210$ & 6 & 30 & 30 & $20-40$ & 3 \\
\hline & 2 & $<30$ & 20 & $<20-50$ & 6 & 50 & 20 & $10-110$ & 6 & 63 & 20 & $20-300$ & 7 \\
\hline & 3 & $<20$ & 20 & $<20-40$ & 6 & $<20$ & 20 & $<20-20$ & 5 & 30 & 20 & $10-60$ & 3 \\
\hline & 4 & $<40$ & 20 & $<20-60$ & 3 & $<30$ & 20 & $<20-30$ & 4 & 17 & 20 & $10-20$ & 3 \\
\hline & 5 & -- & -- & -- & -- & -- & -- & -- & -- & 23 & 20 & $20-30$ & 3 \\
\hline
\end{tabular}

High flow

Total copper

Total iron

Total mercury

$\begin{array}{lrc}7.4 & 8 & 0-14 \\ 7 & 5 & 0-22 \\ 9.2 & 7 & 2-15 \\ <8 & 5 & <2-<20 \\ -- & -- & --\end{array}$

4,700

4,000

5,600

2,400

1,500
2,700
7,000
1,700

$\begin{array}{lll}1,000-13,000 & 5 & 2,800 \\ 1,000-9,700 & 7 & 3,800\end{array}$

$\begin{array}{lll}1,000-9,700 & 7 & 3,800 \\ 1,000-9,000 & 5 & 3,800\end{array}$ $\begin{array}{ccc}620-5,800 & 7 & 1,800 \\ -- & -- & \end{array}$

8001,600

$6 \quad 4-45$

13
9
12

12
6

$<.5$

$<.5$

$<.5$

$<.5$

\begin{tabular}{c}
6 \\
7 \\
7 \\
5 \\
-- \\
\\
$<$ \\
$<$ \\
$<$ \\
$<$ \\
\hline
\end{tabular}

$4-45$
$0-23$

$0-38$

$0-11$

$$
--
$$$$
-
$$

40
$<40$
40
$<30$

$<.5$
$<.5$
$<.5$
$<.5$
--

5
7
5
7
--
3
4
3
4
--

8
10
13
3
--
$<.1$
$<.1$
$<.2$
$<.1$

$\begin{array}{rrrr}40 & 20-60 & 5 & 100 \\ 40 & <20-60 & 7 & 50 \\ 30 & 20-60 & 5 & 60 \\ 30 & <20-40 & 7 & 20 \\ -- & -- & -- & -\end{array}$

\begin{tabular}{r|}
7 \\
8 \\
14 \\
4 \\
--
\end{tabular}

\section{$<.1<.1$ \\ $<.1<.1-2$}

$<.1$

$<.1-.1$

\begin{tabular}{r|cc}
100 & $20-180$ & 3 \\
40 & $10-130$ & 5 \\
60 & $20-110$ & 3 \\
20 & $10-40$ & 5 \\
-- & -- & --
\end{tabular}

5.7
6.8
6.3
4.3
4.2

$\begin{array}{llr}5 & 3-12 & 7 \\ 7 & 2-14 & 13 \\ 6.5 & 3-8 & 6 \\ 4.5 & 2-7 & 6 \\ 4 & 3-7 & 5\end{array}$

860

770
1,300

$\begin{array}{ll}1,500 & 1,300 \\ 1,900 & 1,400\end{array}$

$\begin{array}{rr}1,900 & 1,400 \\ 1,400 & 885\end{array}$

$1,200 \quad 1,500$

$0-16$

$0-19$

$1-23$

-

$\begin{array}{ll}3 & 2 \\ 6 & 5 \\ 5 & 4 \\ 2 & 2 \\ 3 & 2\end{array}$

$\begin{array}{rcr}2 & 11-5 & 7 \\ 5 & 1-14 & 13 \\ 4 & 1-12 & 6 \\ 2 & 1-4 & 6 \\ 2 & 1-5 & 5\end{array}$

$\begin{array}{llll}.1 & .1 & .1-.3\end{array}$

$\begin{array}{lll}.1 & .1 & .1-.3\end{array}$

$.2 \quad .1 \quad .1-.7$

$.1 \quad .1 \quad .1-.2$

$.1-.3 \quad 5$

$\begin{array}{rrrr}20 & 20 & 10-30 & 7 \\ 28 & 20 & 20-40 & 13 \\ 22 & 20 & 10-40 & 6 \\ 15 & 15 & 10-20 & 6 \\ 18 & 10 & 10-30 & 5\end{array}$




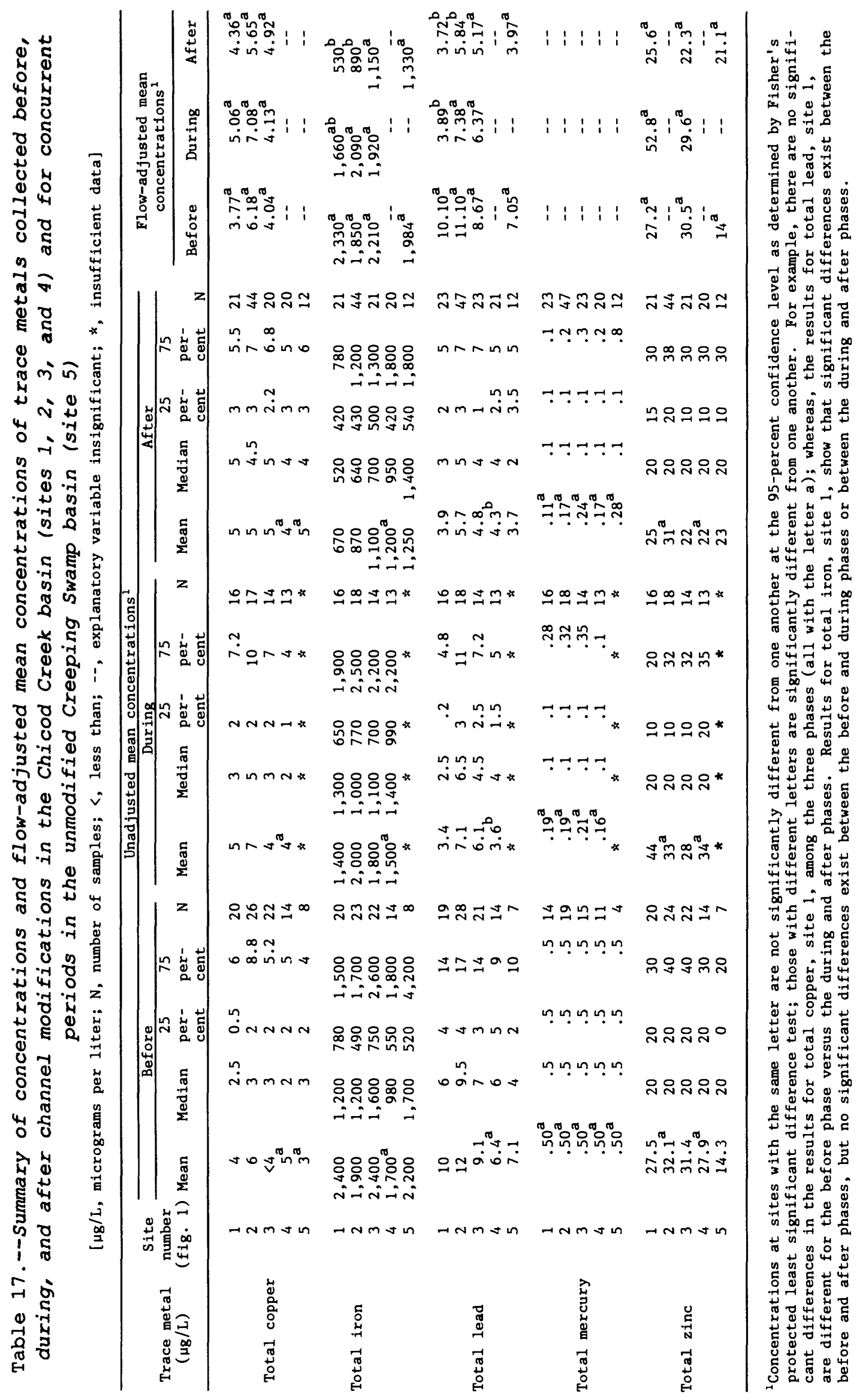


trations during modification. A comparison of the before-modification mean concentration with the after-modification mean concentration indicates an overal1 decrease in flow-adjusted mean total concentrations of 52 percent for total iron and 48 percent for total lead.

No statistically significant changes in trace metals concentrations were detected at Cow Swamp (site 3); however, at upstream Chicod Creek (site 4) the unadjusted mean total lead concentration (lead was not significantly related to discharge) decreased 44 percent during channel modification. After modification, unadjusted mean lead concentrations increased slightly in stream water, but the overall decrease was 33 percent.

The changes in trace metals observed in the unmodified control basin, Creeping Swamp, varied slightly and showed both increases and decreases in concentrations during the study. Copper and zinc increased over corresponding construction periods, and iron, lead, and mercury decreased; however, the observations were fewer than in the Chicod Creek basin and were not considered statistically significant (table 17).

The reductions in lead concentrations in Juniper Branch (site 1) and Chicod Creek (sites 2 and 4 ) were probably caused by reductions in the lead concentrations in precipitation. Similar reductions in lead concentrations in other streams have been reported and were attributed to reductions in lead concentration of precipitation following reduced use of leaded gasolines (Smith and others, 1987). Total lead concentrations also decreased at the control site, Creeping Swamp (site 5), although this decrease was not statistically significant. The reductions in lead concentrations tends to support the hypothesis that the decreases in lead concentrations at the modified sites were caused partly by decreases in precipitation concentrations rather than solely caused by channel modifications.

The reductions in iron concentrations in Juniper Branch and Chicod Creek are probably related to changes in particle size and composition of bottom and suspended sediments following channel modifications. O'Rear (1975) documented differences in sediment composition between a channelized reach versus a unchannelized reach of Swift Creek in Pitt County. He described a finer, less homogenous sediment in the unchannelized reach and reported that metal concentrations tended to be higher in the bottom sediments of the unchannelized reach than the channelized reach. He pointed to the greater amount of organic material in the sediments of the unchannelized reach as the possible cause of the higher metal concentration. 
A similar shift in sediment size may have occurred in the Chicod Creek basin following channel modifications, but there are no particle-size analyses of suspended sediment and few particle-size analyses of bottom material with which to establish such changes with certainty. Visual observations of streambeds before and after modifications indicate that average particle sizes of bottom sediments have increased. Prior to channel modification, most of the Juniper Branch streambed was covered by black silts and mud. After channel modification, beds along excavated reaches were lined by coarser sands.

It seems likely that excavation of the channel removed some of the fine materials from the streams either as spoil or through suspension and transport in the water. Finer particles, because of greater surface area to mass ratios, tend to be more efficient collectors of trace metals. Aggravation and suspension of the bed material, removal of aquatic plants which might have otherwise trapped fine sediments, and an increase in streamflow velocity may have caused the smaller particles and their metal content to migrate out of the basin during modifications.

\section{$\underline{\text { Pesticides }}$}

Some organic compounds, such as pesticides, readily attach to clays and fine organic particles. During storms, these particles are transported from cultivated areas by erosion and are deposited in streambeds and along stream courses. Exposure of these sediments at later dates by excavation or by natural stream-channel degradation makes them available for fluvial transport, thereby producing elevated pesticide levels in streams during floods.

Samples of bottom material and water were collected at each site in the Chicod Creek basin periodically over a broad range of flow conditions between February 1976 and June 1981. No samples were collected at the Creeping Swamp control site. These samples were analyzed for organochlorine pesticides and for two other groups of toxic organic compounds, polychlorinated biphenyls (PCB) and polychlorinated naphthalenes (PCN).

In each of the 24 bottom-material samples, at least one of the pesticides chlordane, DDD, DDE, DDT, dieldrin, endrin, or heptachlor was detected (table 18). PCB was observed in four samples, but no PCN was observed. Dieldrin, DDT, DDD, and DDE were the most frequently observed compounds. 


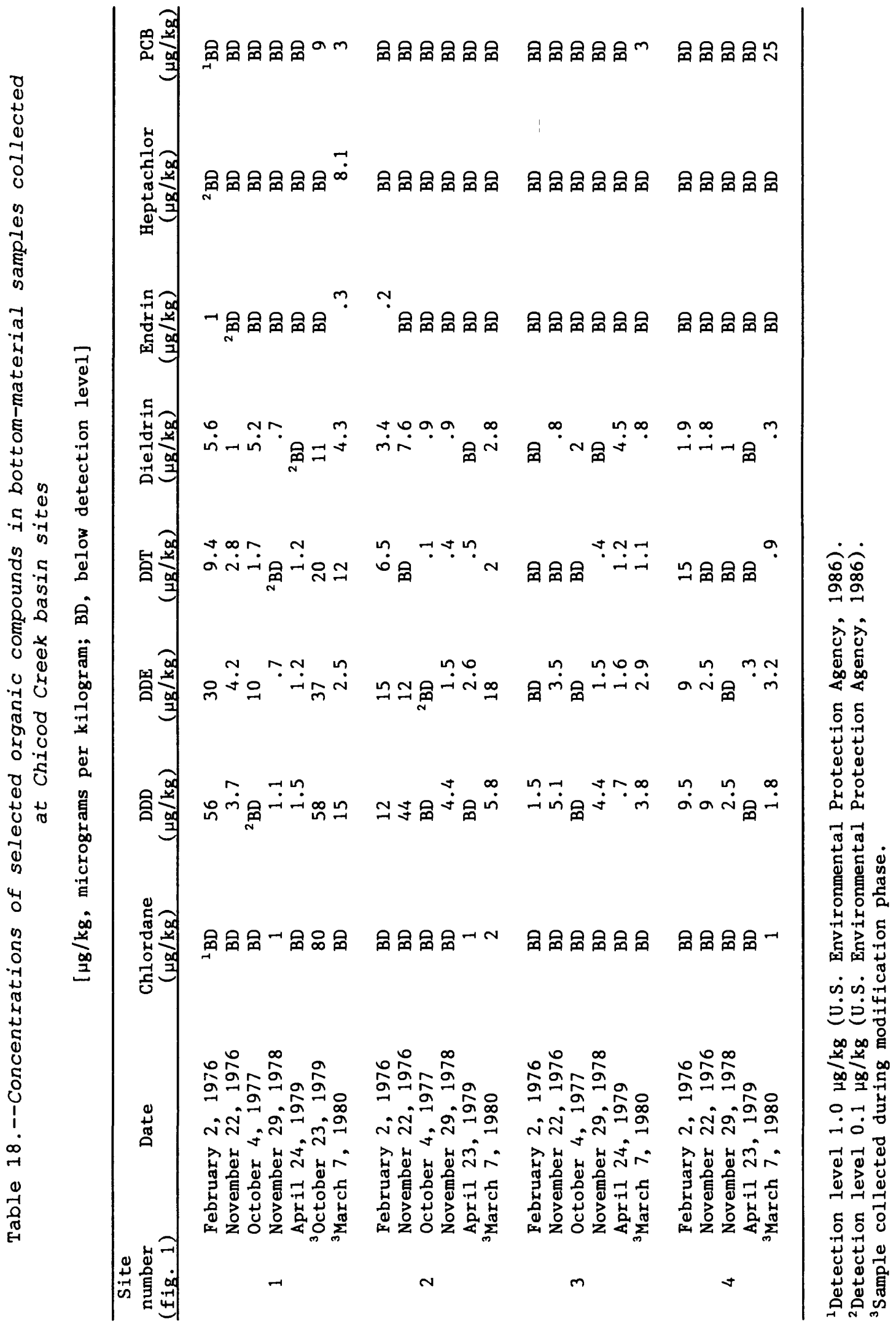


Detectable levels of several pesticides were found in the waters of Chicod Creek basin (table 19). Although no specific pesticide was always present at detectable levels, dieldrin occurred most frequently at all four sites and ranged in concentrations from less than 0.01 to $0.02 \mu \mathrm{g} / \mathrm{L}$. DDT was detected at three sites, but less frequently than dieldrin, at concentrations of $0.01 \mu \mathrm{g} / \mathrm{L}$ or less. No other pesticides, PCBs or PCNs, were detected in water samples from sites 1,3 , and 4, although diazinon was detected in one sample at site 2 .

Table 19.--Concentrations of selected total pesticides, discharge, and suspended-sediment concentrations of instream samples at Chicod Creek basin sites

$\left[\mathrm{ft}^{3} / \mathrm{s}\right.$, cubic feet per second; $\mathrm{mg} / \mathrm{L}$, milligrams per liter; $\mu \mathrm{g} / \mathrm{L}$, micrograms per liter; $\mathrm{BD}$, below detection level]

\begin{tabular}{|c|c|c|c|c|c|c|}
\hline \multirow{2}{*}{\multicolumn{2}{|c|}{$\begin{array}{c}\text { Site } \\
\text { number } \\
(\text { fig. 1) } \\
\end{array}$}} & \multirow[b]{2}{*}{$\begin{array}{c}\text { Discharge } \\
\left(\mathrm{ft}^{3} / \mathrm{s}\right)\end{array}$} & \multirow{2}{*}{$\begin{array}{l}\text { Suspended } \\
\text { sediment } \\
(\mathrm{mg} / \mathrm{L})\end{array}$} & \multicolumn{3}{|c|}{ Pesticides, total } \\
\hline & & & & $\begin{array}{c}\mathrm{DDT} \\
(\mu \mathrm{g} / \mathrm{L})\end{array}$ & $\begin{array}{c}\text { Dieldrin } \\
(\mu \mathrm{g} / \mathrm{L})\end{array}$ & $\begin{array}{c}\text { Diazinon } \\
(\mu \mathrm{g} / \mathrm{L})\end{array}$ \\
\hline \multirow{9}{*}{1} & February 2, 1976 & 56 & 39 & ${ }^{1} \mathrm{BD}$ & ${ }^{1} \mathrm{BD}$ & ${ }^{1} \mathrm{BD}$ \\
\hline & June 2,1976 & .70 & 9 & $\mathrm{BD}$ & 0.01 & $\mathrm{BD}$ \\
\hline & November 22, 1976 & 1.6 & 7 & $\mathrm{BD}$ & $\mathrm{BD}$ & $\mathrm{BD}$ \\
\hline & October 4, 1977 & .19 & 12 & BD & BD & $\mathrm{BD}$ \\
\hline & November 29,1978 & 1.1 & 3 & $\mathrm{BD}$ & BD & $\mathrm{BD}$ \\
\hline & April 24, 1979 & 3 & 9 & $\mathrm{BD}$ & $\mathrm{BD}$ & $\mathrm{BD}$ \\
\hline & ${ }^{2}$ October 23,1979 & 1.2 & 12 & $\mathrm{BD}$ & $\mathrm{BD}$ & $\mathrm{BD}$ \\
\hline & ${ }^{2}$ October 24,1979 & 1.5 & 21 & $\mathrm{BD}$ & $\mathrm{BD}$ & $\mathrm{BD}$ \\
\hline & ${ }^{2}$ March 7, 1980 & 38 & 85 & $\mathrm{BD}$ & $\mathrm{BD}$ & $\mathrm{BD}$ \\
\hline \multirow{8}{*}{2} & February 2, 1976 & 375 & 68 & 0.01 & .01 & $\mathrm{BD}$ \\
\hline & June 2, 1976 & 5.6 & 26 & $\mathrm{BD}$ & BD & $\mathrm{BD}$ \\
\hline & November 22,1976 & 8.2 & 9 & $\mathrm{BD}$ & $\mathrm{BD}$ & $\mathrm{BD}$ \\
\hline & October 4, 1977 & .12 & 8 & $\mathrm{BD}$ & $\mathrm{BD}$ & $\mathrm{BD}$ \\
\hline & November 29,1978 & 4.6 & 14 & BD & $\mathrm{BD}$ & $\mathrm{BD}$ \\
\hline & April 23, 1979 & 23 & 13 & $\mathrm{BD}$ & $\mathrm{BD}$ & $\mathrm{BD}$ \\
\hline & ${ }^{2}$ March 7, 1980 & 632 & 53 & $\mathrm{BD}$ & $\mathrm{BD}$ & $\mathrm{BD}$ \\
\hline & ${ }^{2}$ June 7,1981 & 890 & 216 & .01 & .02 & 0.01 \\
\hline \multirow{7}{*}{3} & February 2, 1976 & 288 & 128 & .01 & .02 & BD \\
\hline & June 2, 1976 & .45 & 16 & $\mathrm{BD}$ & $\mathrm{BD}$ & $\mathrm{BD}$ \\
\hline & November 22,1976 & 2.7 & 71 & $\mathrm{BD}$ & $\mathrm{BD}$ & $\mathrm{BD}$ \\
\hline & October 4, 1977 & .39 & 7 & $\mathrm{BD}$ & $\mathrm{BD}$ & BD \\
\hline & November 29,1978 & 1.8 & 5 & $\mathrm{BD}$ & $\mathrm{BD}$ & $\mathrm{BD}$ \\
\hline & April 24, 1979 & 6.7 & 12 & $\mathrm{BD}$ & .01 & $\mathrm{BD}$ \\
\hline & ${ }^{2}$ March 7, 1980 & 179 & 54 & $\mathrm{BD}$ & $\mathrm{BD}$ & $\mathrm{BD}$ \\
\hline \multirow{7}{*}{4} & February 2, 1976 & 70 & 50 & $\mathrm{BD}$ & .01 & $\mathrm{BD}$ \\
\hline & June 2, 1976 & 3.5 & 15 & $\mathrm{BD}$ & $\mathrm{BD}$ & $\mathrm{BD}$ \\
\hline & November 22,1976 & 4.6 & 3 & BD & BD & BD \\
\hline & November 29,1978 & .01 & 17 & $\mathrm{BD}$ & $\mathrm{BD}$ & BD \\
\hline & April 23, 1979 & 7.8 & 5 & $\mathrm{BD}$ & .01 & $\mathrm{BD}$ \\
\hline & ${ }^{2}$ March 7, 1980 & 212 & 28 & $\mathrm{BD}$ & $\mathrm{BD}$ & $\mathrm{BD}$ \\
\hline & ${ }^{2}$ June 7,1981 & 304 & 70 & .01 & .01 & BD \\
\hline
\end{tabular}

${ }^{1}$ Detection level $0.01 \mu \mathrm{g} / \mathrm{L}$ (U.S. Environmental Protection Agency, 1986).

${ }^{2}$ Sample collected during modification phase. 
Dieldrin was detected in water samples bver a broad range of discharges from 0.7 to $890 \mathrm{ft}^{3} / \mathrm{s}$, but DDT seemed to be associated with higher flows of 304 to $890 \mathrm{ft}^{3} / \mathrm{s}$. Because of the sparsity of samples during or after channe1 modification, it is impossible to ascertain whether or not changes in concentrations of these pesticides in water or bottom material was related to channel modification.

\section{Bacteria}

The presence of fecal coliform and fecal streptococcus bacteria indicate fecal-waste contamination by warm-blooded animals. Bacteriological counts from periodic samples at all Chicod Creek sites were obtained during all phases of channel modifications and over a wide range of streamflows. No samples were collected in the Creeping Swamp control basin for bacteriological analysis.

Biologists use the ratio of fecal coliform (FC) counts to fecal streptococci (FS) counts to determine the source of the bacteria. A FC/FS ratio less than 0.7 indicates that the source of the bacteria is poultry or 1 ivestock, whereas a ratio greater than 4 indicates that human wastes predominate (Geldrich and Kenner, 1969). Only 2 of 148 samples had a FC/FS ratio of more than 4 (table 20); these data are insufficient to test for any significance. However, 126 samples were determined to have a FC/FS ratio of less than 0.7 , which indicates a livestock source of the bacteria.

In general, the bacteriological counts were higher during high streamflows than during base flow, but occasional high counts also occurred during base-flow periods (table 20). High coliform counts during base-flow conditions probably resulted from livestock having direct access to streams in the basin.

Fecal coliform and fecal streptococci counts (table 20) before, during, and after channel modifications were not significantly different as revealed by an analysis of covariance. However, according to criteria established by the U.S. Environmental Protection Agency (1986), fecal coliform counts of streams in the Chicod Creek basin commonly exceed recommended limits for bathing waters and shellfish harvesting throughout the study. 


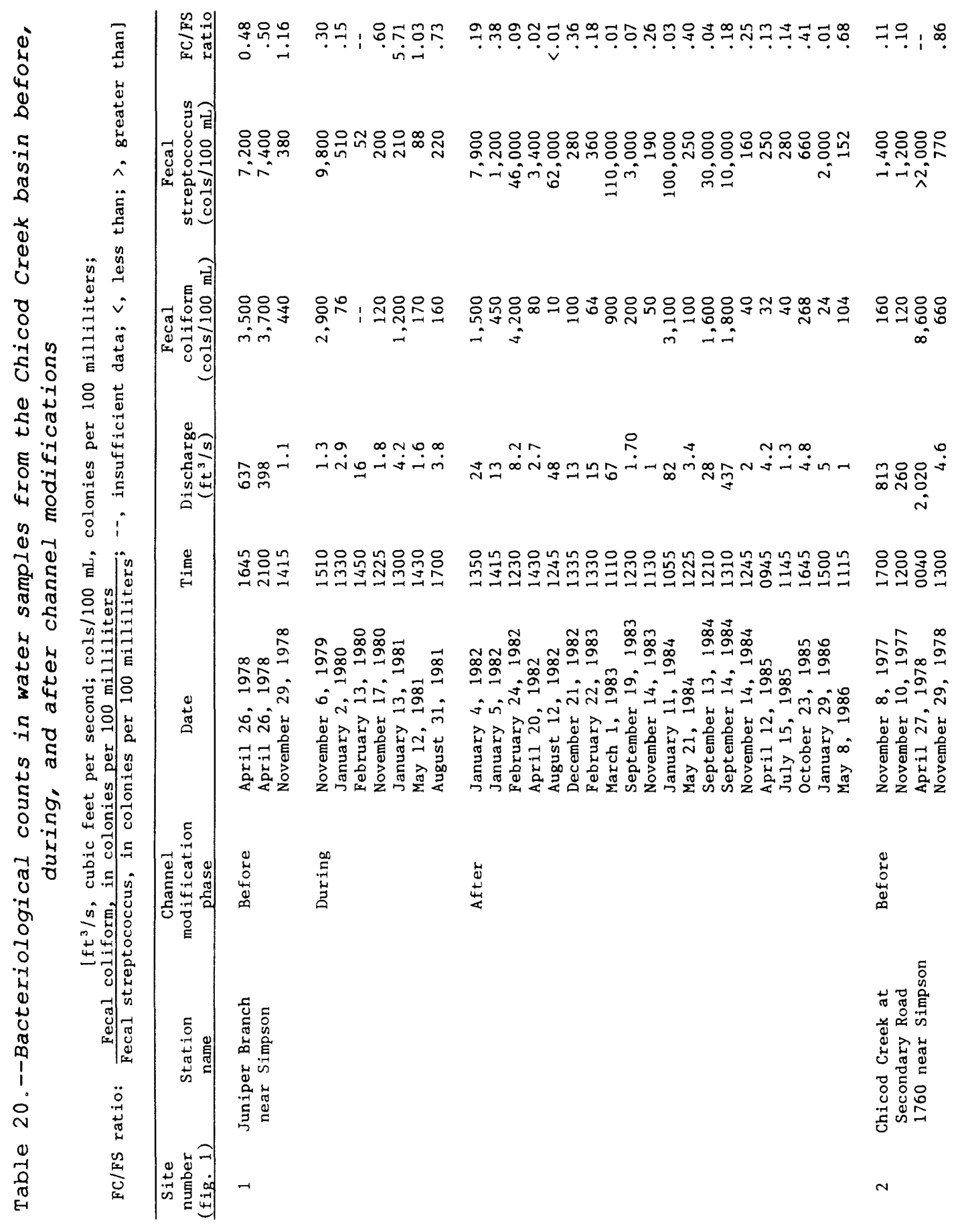




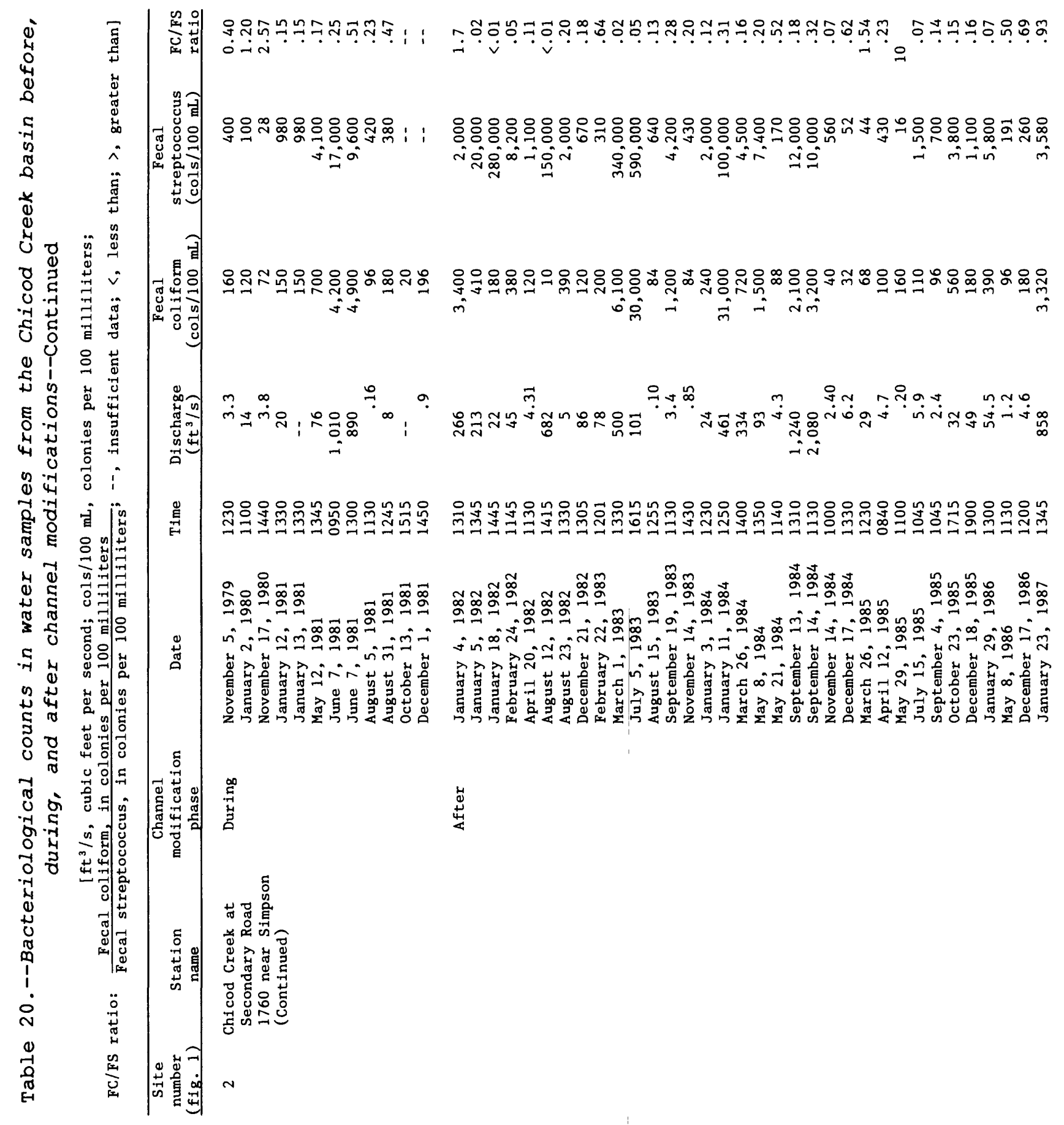




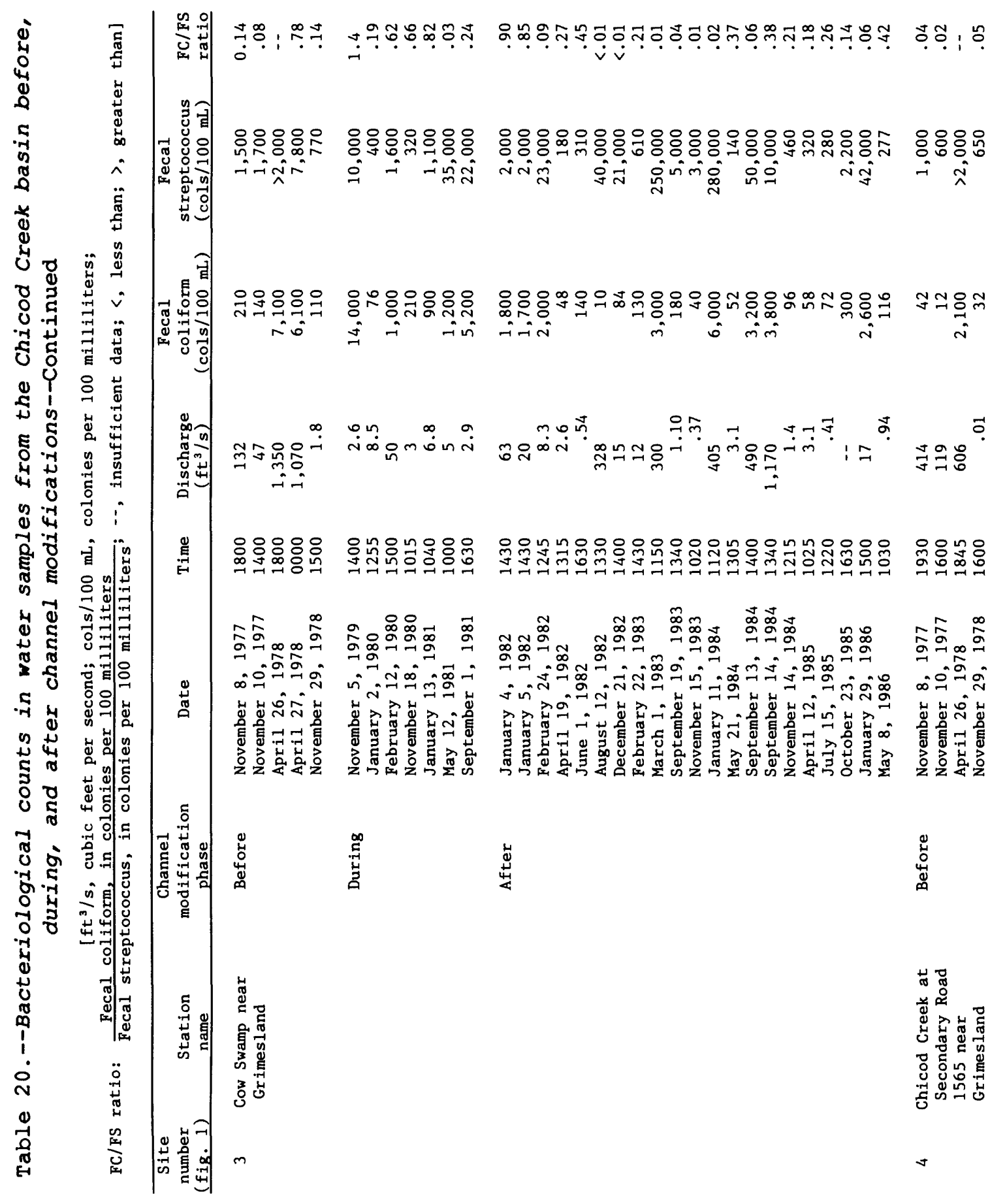




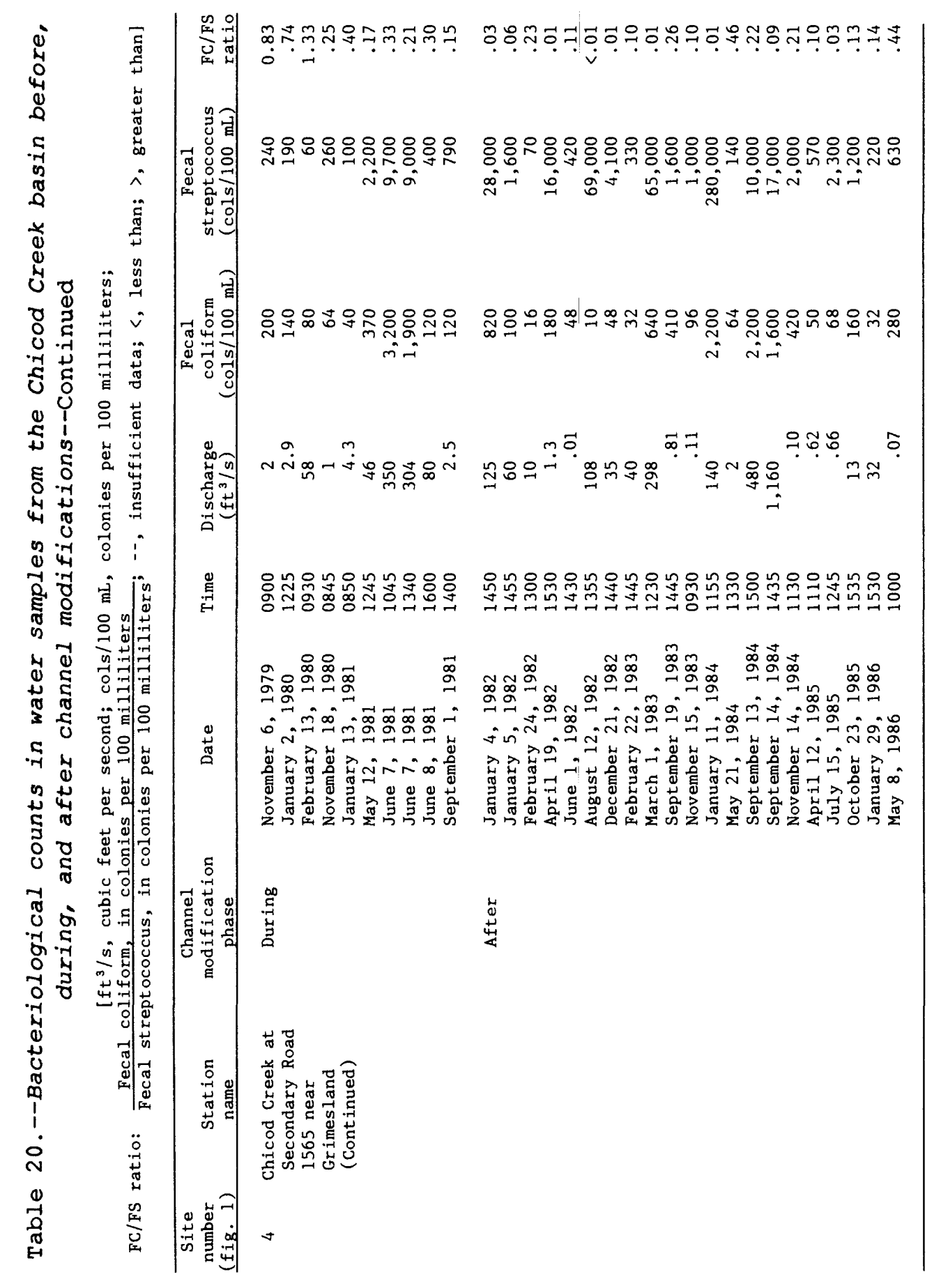




\section{SUMMARY}

From 1978 to 1981, selected stream channe1s throughout the 60-squaremile Chicod Creek basin underwent modifications to increase drainage efficiency and reduce flooding potential. Drainage modifications in this Coastal Plain basin consisted primarily of channel excavation and clearing of channel blockages. The hydrologic conditions of the basin before, during, and after modifications were determined from observed data that included surface-water flow, ground-water levels, and selected water-quality constituent concentrations. These data also were collected in an adjacent unmodified basin, Creeping Swamp, for comparison with an undisturbed basin.

Channel modifications caused significant changes in several hydrologic characteristics of the Chicod Creek basin. By the end of the datacollection period, March 1987, some of the physical hydrologic characteristics nearly had returned to premodification conditions after channel modifications were completed, but most chemical water-quality characteristics had not.

Streamflow characteristics changed substantially during the modifications, especially at base flow. Base flows generally were higher during channel modifications. After modification, base flows decreased slightly but did not return to premodification conditions. For instance, minimum flows in Juniper Branch (site 1 ) were 1 ess than $0.1 \mathrm{ft} / \mathrm{s}$ approximately 11 percent of the time before channel modification; during modification, minimum flows exceeded $0.4 \mathrm{ft} / \mathrm{s}$ at all times. After modification, daily flows were zero less than 0.1 percent of the time, and flow was nearly $0.9 \mathrm{ft}^{3} / \mathrm{s} 11$ percent of the time.

At Chicod Creek (site 2) base flow increased during modification and increased slightly more after modification. Before modification, flow at site 2 was less than $0.1 \mathrm{ft}^{3} / \mathrm{s}$ approximately 13 percent of the time. During modification, flow fell below $0.1 \mathrm{ft}^{3} / \mathrm{s}$ only 6 percent of the time and after modification, flow was less than $0.1 \mathrm{ft}^{3} / \mathrm{s}$ only 3 percent of the time.

Streamflow variability was reduced at sites 1 and 2 during and after channel modifications but remained virtually unchanged at the control basin site. The variability index decreased from 0.87 to 0.49 at Juniper Branch and decreased from 1.24 to 0.80 at Chicod Creek.

Excavation increased the carrying capacity (conveyance) of streams in the Chicod Creek basin and reduced the occurrence of overbank flows. For example, prior to excavation the channel capacity of Juniper Branch near Pi- 
527 ranged from 2 to $10 \mathrm{ft}^{3} / \mathrm{s}$. A daily mean flow of more than $10 \mathrm{ft}^{3} / \mathrm{s}$ occurred on more than 155 days before modifications. During modification, the channel capacity was increased to $88 \mathrm{ft}^{3} / \mathrm{s}$, which was probably exceeded on only 5 days during this period. After modification, channel capacity declined to $44 \mathrm{ft}^{3} / \mathrm{s}$ because of partial filling of the channel by sediment. A daily mean flow of $44 \mathrm{ft}^{3} / \mathrm{s}$ at this site was exceeded on only 36 days after modification. Thus, parts of Juniper Branch flood plain that were common1y inundated before modification were infrequently inundated after modification.

Streamflow velocity increased at site 2. Velocity increases were greatest in flows confined within the channel, whereas increases were slight in overbank flows. This tendency is consistent with the physical modifications made to the stream channe1. On1y the channe1 bottoms and sides were cleared and snagged; no changes were made to the overbank portion of the flood plain.

The shape and timing of hydrographs were also changed as a result of channel modifications. Peak flows were higher and their duration shorter after the modifications.

Channel excavations temporarily altered the movement of ground-water through the shallow aquifer system, ground-water fluctuations near streams, and increased base flow to streams. The total rainfall-runoff relation at Juniper Branch for the entire study period was unchanged; however, this indicated that the increase in base flow was offset by a decrease in storm runoff. During the modification period, channel excavations of 2 to $3 \mathrm{ft}$ in Juniper Branch caused a decline in the water table as much as $0.4 \mathrm{ft}$ in we1l $\mathrm{Pi}-527$, about $180 \mathrm{ft}$ from the channel. About $250 \mathrm{ft}$ from the channe1, the decline was $0.2 \mathrm{ft}$ in well $\mathrm{Pi}-528$. After the modification period, the water table returned nearly to premodification levels, presumably because of partial refilling of the excavated channel with sediment.

Stream-quality characteristics in three general categories were examined: physical, chemical, and bateriological characteristics. Only one physical characteristic, suspended sediment, showed a significant increase during channel modifications. Examination of sediment-transport curves for Juniper Branch (site 1) and Chicod Creek (site 4) indicate that suspendedsediment discharges generally were statistically greater during channel modification than before. For example, at Juniper Branch, sediment discharge increased from 20 to 50 tons/d during modifications at a flow rate of $100 \mathrm{ft}^{3} / \mathrm{s}$. After modification, suspended-sediment concentrations tended 
to return to before-modification levels, probably in response to stabilization of streambeds and banks. There were no statistically significant changes in sediment discharge at Chicod Creek (site 2) and Cow Swamp (site 3 ).

Mean stream temperatures ranged from 9 to $17{ }^{\circ} \mathrm{C}$ during base flows and from 13 to $19^{\circ} \mathrm{C}$ during floods, but there were no statistically significant differences in temperature were observed between the three phases of channel modifications. There were no statistically significant changes in dissolved-oxygen concentrations before, during, and after channel modifications, nor were there any statistically significant changes in the $\mathrm{pH}$ of stream water.

Statistically significant changes in some chemical constituents were observed at Juniper Branch (site 1) during channel modifications. These included calcium, 35 percent; magnesium, 26 percent; bicarbonate, 78 percent; silica, 20 percent; dissolved solids, 31 percent; total nitrogen, 49 percent; total iron, -77 percent; and total lead, -63 percent.

At Chicod Creek (site 2) significant changes in chemical constituents were observed extensively in both the during and after modification phases. The overall changes were: calcium, 49 percent; magnesium, 32 percent; sodium, 14 percent; potassium, 51 percent; bicarbonate, 64 percent; sulfate, 34 percent; chloride, 20 percent; dissolved solids, 32 percent; total nitrite, 130 percent; total nitrate, 100 percent; total nitrogen, 110 percent; total phosphorus, 69 percent; total iron, -52 percent; and total lead, -48 percent. Significant changes in fewer chemical constituents occurred at Cow Swamp (site 3) and Chicod Creek (site 4).

Changes in concentrations of some dissolved constituents resulted from channel excavation. Deepening the channels caused greater ground-water discharge to the streams, thus, increasing concentrations of some dissolved constituents associated with the ground water.

Increases in the concentration of nutrients may be related to channel modification, but concurrent changes in land use, agricultural practices, and increases in livestock populations are probably responsible for the increases at some or all sites.

Decreases in concentrations of total iron may be related to channel modification, but decreases in total lead concentrations are probably related to changes in atmospheric deposition.

Dieldrin, DDT, DDD, and DDE were the most frequently observed pesticides in samples of stream-bottom materials. Dieldrin and DDT were 
found in water samples at concentrations of less than 0.01 to $0.02 \mu \mathrm{g} / \mathrm{L}$. Data were insufficient to determine the significance of changes in pesticide concentrations.

Bacteriological data indicate that surface water at all four sampling sites is subject to fecal contamination. A FC/FS ratio of less than 0.7 in about 98 percent of the samples indicate domestic livestock or poultry to be the most likely source of the bacteria. No significant change in bacteria counts were detected during or after channel modifications.

\section{SELECTED REFERENCES}

Brookes, A., 1985, River channelization: Traditional engineering methods, physical consequences and attunative practices: Progress in Physical Geography, v. 9 (1), p. 44-73.

Carlile, B.L., Cogger, C.G., and Steinbeck, S.J., 1981, Movement and treatment of effluent in soils of the lower Coastal Plain of North Carolina: Raleigh, North Carolina, Division of Health Services, North Carolina Department of Human Resources, p. 60.

Coffey, Albert, 1982, Stream improvement: The Chicod Creek episode, in Journal of soil and water conservation: Soil Conservation Society of America, v. 37, no. 2, p. 80-82.

Danie1, C.C., III, 1981, Hydrology, geology, and soils of pocosins: A comparison of natural and altered systems, in Richardson, C.J., ed., Pocosin wetlands: Stroudsburg, Pa., Hutchinson Ross, p. 69-108.

Duve1, W.A., Volkman, R.D., Specht, W.L., and Johnson, F.W., 1976 , Environmental impact of stream channelization, in Water resources bulletin, v. 12, no. 4: American Water Resources Association, $12 \mathrm{p}$.

Federal Interagency Work Group, 1977, National handbook of recommended methods for water-data acquisition: U.S. Geological Survey, Office of Water Data Coordination, 193 p.

Geldreich, E.E., and Kenner, B.A., 1969, Concepts of fecal streptococci in stream pollution, in Journal of the water pollution control federation, v. 41, part 2: Water Pollution Control Federation, p. A336-352.

Goddard, G.C., Jr., 1963, Water-supply characteristics of North Carolina streams: U.S. Geological Survey Water-Supply Paper 1761, 233 p.

Greeson, P.C., Ehlke, T.A., Irwin, G.A., Lium, B.W., and Slack, K.V., eds., 1977, Methods for collection analysis of aquatic biological and microbiological samples: U.S. Geological Survey Techniques of WaterResources Investigations, bk. 5, chap. A4, $332 \mathrm{p}$. 
Hahn, S.S., 1982, Stream channelization: Effects on stream fauna, in Greeson, P.C., ed., Biota and biological principles of the aquatic environment: U.S. Geological Circular 848-A, p. A43-A49.

Harvey, M.D., Watson, C.C., Schumm, 1985, Stream channel restoration criteria, in Proceedings of 2nd hydrology symposium on surface coal mining in the northern Great Plains, Feb. 26-27: Gillette, Wyoming, p. $61-73$.

Heath, R.C., 1975, Hydrology of the Albemarle-Pamlico region North Carolina: U.S. Geological Survey Water-Resources Investigations Report 75-9, $98 \mathrm{p}$.

Hem, J.D., 1985, Study and interpretation of the chemical constituents of natural water, ( $3 \mathrm{~d}$ ed.): U.S. Geological Survey Water-Supply Paper $2254,263 \mathrm{p}$.

Herb, W.J., 1980, Sediment-trap efficiency of a multi-purpose impoundment, North Branch Rock Creek basin, Montgomery County, Maryland, 1968-76: U.S. Geological Survey Water-Supply Paper 2071, 41 p.

Horowitz, A.J., 1985, A primer on trace metal-sediment chemistry: U.S. Geological Survey Water-Supply Paper 2277, 67 p.

Humenik, F.J., Bliven, L.F., Overcash, M.R., and Koehler, F., 1980, Rural nonpoint source water quality in a southeastern watershed, in Journal of water pollution control federation, v. 52, no. 1: Water Pollution Control Federation, January, p. 29-43.

Hutchinson, N.E., 1975, WATSTORE user's guide, volume 1: U.S. Geological Survey Open-File Report 75-426.

Krenkel, P.A., and Novotny, Vladimir, 1980, Water quality management: San Francisco, Academic Press, 671 p.

Kuenzler, E.J., Mulholland, P.J., Ruley, L.A., and Sniffen, R.P., 1977, Water quality in North Carolina Coastal Plain streams and the effects of channelization: Raleigh, North Carolina, Water Resources Research Institute, Report no. 127, North Carolina State University, 160 p.

Lane, E.W., and Lei, Kai, 1950, Streamflow variability, in American Society of Civil Engineers Transactions, v. 115: American Society of Civil Engineers, p. $1084-1134$.

Langbein, W.B., and Iseri, K.T., 1960, General introduction and hydrologic definitions: U.S. Geological Survey Water-Supply Paper 1541-A, 29 p.

National Oceanic and Atmospheric Administration, 1987, Climatological data, annual summary, North Carolina, 1986: Asheville, North Carolina, National Climatic Center, v. 91, no. 13, 35 p. 
North Carolina Department of Agriculture, 1976a-annual1y, North Carolina agricultural statistics: Raleigh, N.C., North Carolina Crop and Livestock Reporting Service, p. 76.

1976b-annually, North Carolina fertilizer tonnage report: Raleigh, N.C., North Carolina Crop and Livestock Reporting Service, p. 15.

O'Rear, C.W., Jr., 1975, The effects of stream channelization on the distribution of nutrients and metals: Raleigh, North Carolina, Water Resources Research Institute, Report no. 108, North Carolina State University, $52 \mathrm{p}$.

Resh, V.H., Brown, A.V., Covich, A.P., Gurtz, M.E., Li, H.W., Minsha11, G.W., Reice, S.R., Sheldon, A.L., Wallace, J.B., and Wissmar, R.C., 1988, The role of disturbance in stream ecology, in Journal of the North American benthological society, v. 7, no. 4: The North American Benthological Society, p. 433-455.

Riggs, H.C., 1972, base-flow investigations: U.S. Geological Survey Techniques of Water-Resources Investigations, bk. 4, chap. Bl, 18 p. Rorabaugh, M.I., 1960, Use of water levels in estimating aquifer constants in a finite aquifer: International Association of Science and Hydrology, no. 52, p. 314-323.

Rosendah1, P.C., and Waite, T.D., 1978, Transport characteristics of phosphorus in channelized and meandering streams, in Water resources bulletin, v. 14, no. 5: American Water Resources Association, 14 p.

Schiebe, F.R., 1984, Evaluation of in-channel excavated sediment traps on Chicod Creek, North Carolina: Durant/Chickasha, Ok1ahoma, U.S. Department of Agriculture, Agriculture Research Station Water Quality and Watershed Research Laboratory, $13 \mathrm{p}$.

Schumm, S.A., Harvey, M.D., Watson, C.C., 1984, Incised channels: morphology, dynamics, and control: Littleton, Colorado, Water Resources Publications, 200 p.

Searcy, J.K., and Hardison, C.H., 1960, Double-mass curves, manual of hydrology: Part 1, general surface-water techniques: U.S. Geological Survey Water-Supply Paper 1541-B, 59 p.

Simmons, C.E., 1988, Sediment characteristics of North Carolina streams, 1970-79: U.S. Geological Survey Open-File Report 87-701, 130 p.

Simmons, C.E., and Aldridge, M.C., 1980, Hydrology of the Chicod Creek basin, North Carolina, prior to channel improvements: U.S. Geological Survey Open-File Report 80-680, 27 p. 
Simmons, C.E., and Watkins, S.A., 1982, The effects of channel excavation on water-quality characteristics of the Black River and ground-water level near Dunn, North Carolina: U.S. Geological Survey Water-Resources Investigations $82-4083,28 \mathrm{p}$.

Smith, R.A., Alexander, R.B., and Wolman, M.G., 1987, Analysis and interpretation of water-quality trends in major U.S. rivers, 1974-81: U.S. Geological Survey Water-Supply Paper 2307, 25 p.

Steel, R.G.D., and Torrie, J.H., 1980, Principles and procedures of statistics: New York, N.Y., McGraw-Hill, 634 p.

U.S. Department of Agriculture, Soil Conservation Service, and U.S. Fish and Wild1ife, 1978, Guidelines for channel modification projects: Federal Register, March 1, 1978, v. 43, no. 41, p. 8276-8280.

U.S. Environmental Protection Agency, 1986, Quality criteria for water 1986: U.S. Environmental Protection Agency EPA 440/5-86-001.

U.S. Geological Survey, 1976 (annua11y), Water resources data for North Carolina, Water year 1976 (annually): U.S. Geological Survey WaterData Reports.

U.S. House of Representatives, 1973, Stream channelization: What federally financed draglines and bulldozers do to our Nation's streams, Fifth report by the Committee on Government operations together with additional views: Washington, D.C. House Report 93-530, U.S. Government Printing office.

Watkins, S.A., and Simmons, C.E., 1984, Hydrologic conditions in the Chicod Creek basin, North Carolina, before and during channel modifications, 1975-81: U.S. Geological Survey Water-Resources Investigations Report $84-4025,36 \mathrm{p}$.

Wetzel, R.G., 1975, Limnology: Philadelphia, Pa., W.B. Saunders Company, $743 \mathrm{p}$.

Wingate, P.J., and Weaver, E., 1977, Environmental assessment, Chicod Creek watershed, Pitt and Beaufort Counties, North Carolina, general report: Raleigh, North Carolina, North Carolina Wildlife Resources Commission, v. 1, p. $1-7$.

Winner, M.D., Jr., and Simmons, C.E., 1977, Hydrology of the Creeping Swamp watershed, North Carolina, with reference to potential effects of stream channelization: U.S. Geological Survey Water-Resources Investigations Report 77-26, $54 \mathrm{p}$.

Yonts, W.L., 1971, base-flow measurements of North Carolina streams: North Carolina Board of Water and Air Resources, Department of Water and Air Resources, 236 p. 
The following definitions are included as a guide to the terminology used in the report:

Adjusted mean value. In analysis of covariance, an expected treatment mean based on a common independent variable value. For example, flow-adjusted mean concentrations before and during excavation are based on a mean flow that represents the entire period of record rather than on individual mean flows for each of the three modification periods.

Analysis of covariance. A statistical model used to adjust mean responses of a dependent variable by an independent variable. Thus, instead of comparing mean concentration before excavation directly to mean concentration during excavation, both means are adjusted through regression to a common mean streamflow and then compared.

Aquifer. A geologic formation, group of formations, or part of a formation that contains sufficient saturated permeable material to yield significant quantities of water to wells and springs.

Bank storage. Water that infiltrates into banks of streams when the stage rises above the water table in the bank formations then returned to the channel as seepage when the stream stages fall below the water table (Langbein and Iseri, 1960, p. 5).

Base flow. Sustained or fair-weather flow of a stream; in most streams, composed largely of ground-water discharge (Langbein and Iseri, 1960, p. 5).

Bottom material. The unconsolidated materila1 of which a streambed, lake, pond, reservoir, or estuary bottom is composed.

Correlation coefficient. A measure of the degree to which two or more variables are linearly related. The correlation coefficient varies from -1 to 1 , where -1 or 1 represents perfect 1 inear relations and 0 represents no linear relation between variables. If the relation between variables increases, the absolute (unsigned) values of the correlation coefficient increases. The simple correlation coefficient, a measure of linear relation between two variables, is referred to as the correlation coefficient in this report. 
Fecal coliform bacteria. Bacteria that are present in the intestines or feces of warm-blooded animals. They are often used as indicators of the sanitary quality of the water. In the laboratory they are defined as all organisms which produce blue colonies within 24 hours when incubated at $44.5^{\circ} \mathrm{C} \pm 0.2{ }^{\circ} \mathrm{C}$ on $\mathrm{M}-\mathrm{FC}$ medium (nutrient medium for bacterial growth). Their concentrations are expressed as number of colonies per $100 \mathrm{~mL}$ of sample.

Fecal streptococcus bacteria. Bacteria found also in intestines of warmblooded animals. Their presence in water is considered to verify fecal pollution. They are characterized as gram-positive, cocci bacteria, which are capable of growth in brain-heart infusion broth. In the laboratory they are defined as all the organisms which produce red or pink colonies within 48 hours at $35^{\circ} \mathrm{C} \pm 1.0^{\circ} \mathrm{C}$ on $\mathrm{M}$-enterrococcus medium (nutrient medium for bacterial growth). Their concentrations are expressed as number of colonies per $100 \mathrm{~mL}$ of sample.

Level of significance. The probability of a result occurring by chance, given a specific set of conditions. Thus, a result having a level of significance of 0.02 could be expected to occur by chance approximately twice in 100 independent trials under stated conditions.

Nutrients. In water, any dissolved or suspended inorganic or organic compound, especially the various forms of nitrogen or phosphorus, used to sustain plant life.

Runoff. That part of precipitation appearing in surface streams (Langbein and Iseri, 1960, p. 17).

Storm runoff. The part of runoff that travels over the soil surface to the nearest stream.

Stormflow. The part of high streamflow entering stream channels promptly after precipitation. Superimposed on base flow, high flowforms the bulk of the hydrograph of a flood.

Streamflow. The discharge or flow of water in a channel or stream.

Student's t test. A standard test of significance generally applied to small samples (30 observations or less) of unknown variance. For example, it is used to test whether the means of two samples differ significantly from one another.

Trap efficiency. The ratio, expressed in percent, of the amount of sediment trapped to the amount of sediment entering the trap (Herb, 1980, p. 33). 
The following factors may be used to convert inch-pound units published in this report to metric (International System) units.

Multiply inch-pound unit By To obtain metric unit

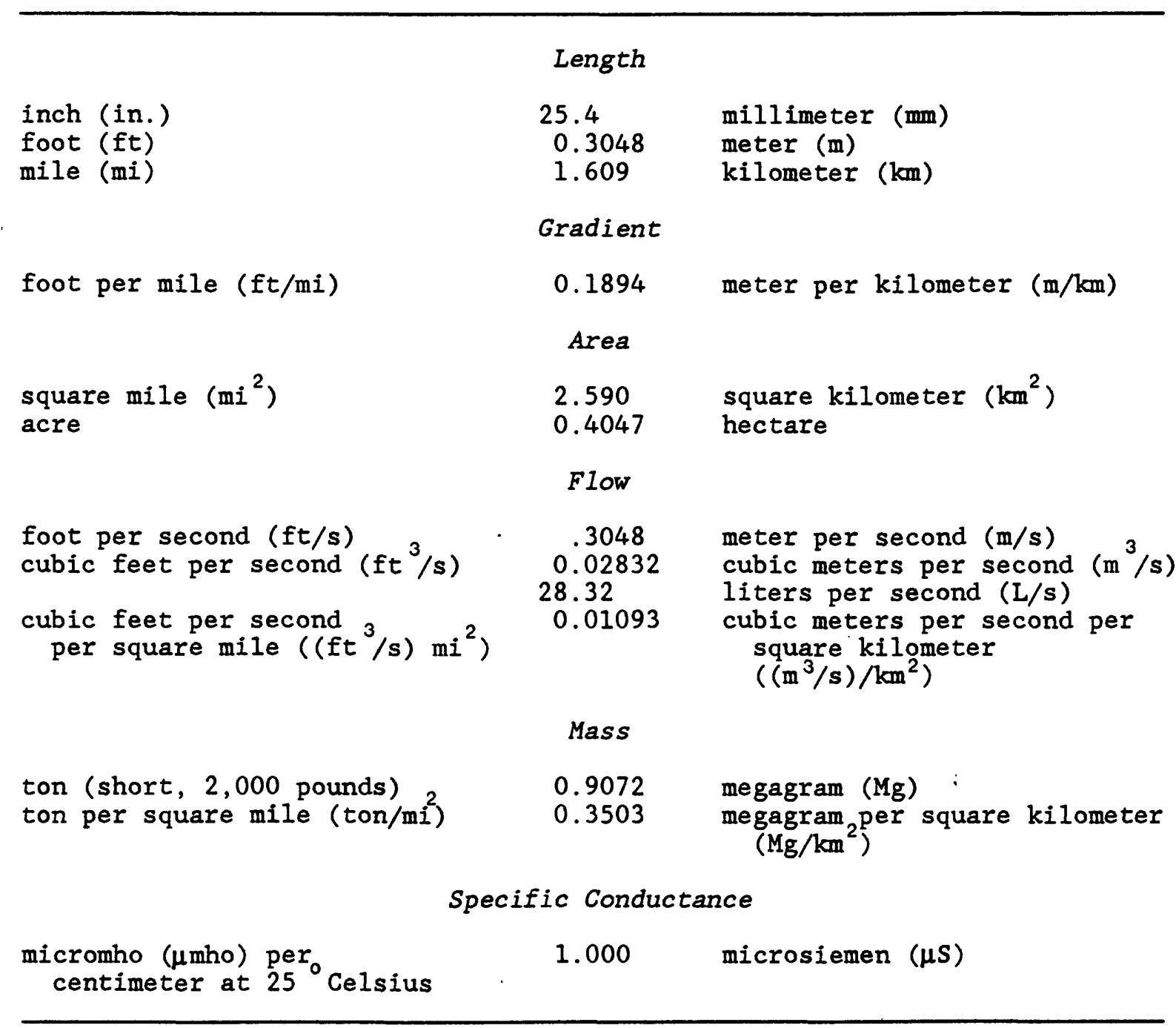

Temperature: In this report temperature is given in degrees Celsius $\left({ }^{\circ} \mathrm{C}\right)$, which can be converted to degrees Fahrenheit $\left({ }^{\circ} \mathrm{F}\right)$ by the following equation: $F=1.8\left({ }^{\circ} \mathrm{C}\right)+32$

Sea level: In this report "sea level" refers to the National Geodetic Vertical Datum of 1929 (NGVD of 1929)--a geodetic datum derived from a general adjustment of the first-order level nets of both the United States and Canada, formerly called Sea Level Datum of 1929. 